\title{
I ndustrial clusters in the long run: Evidence from Million-Rouble plants in China
}

Stephan Heblich, Marlon Seror, Hao Xu and

Yanos Zylberberg

Discussion Paper 19 / 712

Updated 24 January 2020

Original May 2019

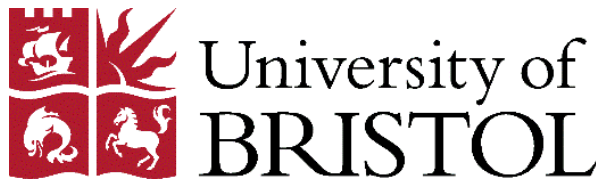

School of Economics

University of Bristol

Priory Road Complex

Bristol BS8 1TU

United Kingdom 


\title{
Industrial clusters in the long run: Evidence from Million-Rouble plants in China*
}

\author{
Stephan Heblich \\ Marlon Seror \\ $\mathrm{Hao} \mathrm{Xu}$ \\ Yanos Zylberberg
}

January 24, 2020

\begin{abstract}
We identify the negative spillovers exerted by large, successful factories on other local production units in China. A short-lived cooperation program between the U.S.S.R. and China led to the construction of 156 "Million-Rouble plants" in the 1950s. The identification exploits the ephemeral geopolitical context and exogenous variation in location decisions due to the relative position of allied and enemy airbases. We find a rise-and-fall pattern in counties hosting a factory and show that (over-) specialization explains their long-run decline. The analysis of production linkages shows that a very large cluster of non-innovative establishments enjoy technological rents along the production chain of Million-Rouble plants. This industrial concentration reduces the local supply of entrepreneurs.
\end{abstract}

JEL codes: R11, R53, J24, N95

\footnotetext{
${ }^{*}$ Heblich: University of Toronto, CESifo, IfW Kiel, IZA, SERC; stephan.heblich@utoronto.ca; Seror: University of Bristol, Paris School of Economics, DIAL, marlon.seror@bristol.ac.uk; Xu: China Construction Bank, sysxuhao@163.com; Zylberberg: University of Bristol, CESifo, Alan Turing Institute; yanos.zylberberg@bristol.ac.uk. This work was part-funded by the Economic and Social Research Council (ESRC) through the Applied Quantitative Methods Network: Phase II, grant number ES/K006460/1, and a BA/Leverhulme Small Research Grant, Reference SRG $\backslash 171331$. We are grateful to Kristian Behrens, Sylvie Démurger, Christian Dustmann, James Fenske, Richard Freeman, Jason Garred, Flore Gubert, Marc Gurgand, Ruixue Jia, Vernon Henderson, Sylvie Lambert, Florian Mayneris, Alice Mesnard, Thomas Piketty, Simon Quinn, Steve Redding, Arthur Silve, Uta Schönberg, Jon Temple, and Liam Wren-Lewis for very useful discussions. We also thank participants at Bristol, DIAL, Laval (Quebec), LSE, Ottawa, Oxford, PSE, Toronto, UCL, UQAM, the EUEA 2018 (Düsseldorf), EEA 2018 (Cologne), UEA 2018 (New York), IOSE 2019 (St Petersburg), EHES 2019 (Paris), Bath, and CURE 2019 (LSE) for helpful comments. We thank Liang Bai, Matthew Turner, Andrew Walder, and Siqi Zheng for sharing data. The usual disclaimer applies.
} 
The structural transformation of agrarian economies involves high spatial concentration of economic activity (Kim, 1995; Henderson et al., 2001). Regions that attract industrial clusters during this transformation process typically experience a boom followed by a bust, as illustrated by declining factory towns in the United States (Detroit and the "Rust Belt"), the United Kingdom (Manchester and other cotton towns), the Ruhr region in Germany, or the Northeast of France. Explanations for such a decline usually rely on external, aggregate factors: (i) structural change, as employment shifts away from industry and into services (Ngai and Pissarides, 2007; Desmet and Rossi-Hansberg, 2014), or (ii) exposure to international competition (Pierce and Schott, 2016).

This paper presents causal evidence of a boom-and-bust cycle across clusters of Chinese firms without any external factor triggering a general decline in manufacturing. This allows us to focus on factors within the industrial clusters that drive their decline. The clusters are characterized by a hub and spoke structure where one (or more) large industrial plant is surrounded by a large network of smaller, noninnovative firms. To investigate individual firm performance and potential spillovers between firms, we employ high-quality data on manufacturing establishments that allow us to measure the firms' productive and innovative performance. We further extend our investigation to the local business environment and look at the presence/absence of entrepreneurs as agents of change.

To establish causality, we exploit an unprecedented investment and technology transfer from the U.S.S.R. to China, which led to the construction of 156 "MillionRouble Plants" (henceforth, MRPs) between 1953 and 1958. These plants, equipped with advanced Soviet technology, constituted the foundation stone of China's industrialization (Lardy, 1987; Naughton, 2007). The allocation of MRPs across Chinese counties itself was not random, and economic factors (e.g., connectedness) were carefully considered by planners. ${ }^{1}$ However, the ephemeral geopolitical context allows us to isolate temporary, exogenous variation in the probability to host a large factory. Coming out of the Korean war, Chinese planners were concerned about the new factories' vulnerability to enemy bombing. We model this threat by combining detailed information about airplane technologies with the location of enemy and allied airbases and instrument a location's probability to host a MRP with this vulnerability measure. $^{2}$

\footnotetext{
${ }^{1}$ In stark contrast with the Great Leap Forward or the Third Front Movement (whose investments had to be "close to the mountains, dispersed, and hidden in caves"), this program was efficiently implemented. The choice of locations for these plants was economically sound and spanned a wide range of locations in China; great attention was also given to production efficiency, including material incentives for managers (Eckstein, 1977; Selden and Eggleston, 1979).

${ }^{2}$ We instrument the treatment (i.e., hosting a MRP) by a measure of vulnerability constructed
} 
We show that counties hosting Million-Rouble plants experience a rise-and-fall pattern. Our estimates show strong positive effects of the " 156 " program until the early 1990s: treated counties were markedly more industrialized, with a 24 percentage points higher employment share in industry, and a two to three times higher productivity than control counties. However, treated counties experienced a steady decline (in relative terms) over the following decades of economic transformation, even though the MRPs themselves remained productive. ${ }^{3}$ In 2010, the employment share in industry was lower in treated counties, and there was no longer a statistically significant difference in productivity.

To assess whether and how MRPs exerted negative spillovers on other production units, we exploit high-quality data on manufacturing establishments (1992-2008) linked with patent applications. We find that the average (other) manufacturing establishment in treated counties is larger, but less productive; it pays lower wages in spite of a more experienced and educated workforce; and it becomes less innovative over time: we observe almost no patent applications during the take-off period of the economy, i.e., between WTO accession and the start of the financial crisis.

We further develop a method to identify treatment heterogeneity across local establishments with different linkages to the MRPs. The analysis of production and technological linkages shows that treated counties are extremely specialized, with a large concentration of establishments clustered along the MRP's production chain. This finding is consistent with specialization during the early phase of industrialization (Glaeser et al., 1992), possibly due to technology adoption or economies of scale (Ciccone, 2002). ${ }^{4}$ Importantly, this specialization is shown to be detrimental in the longer run. The large cluster of linked establishments, upstream and downstream of the $\operatorname{MRP}(\mathrm{s})$, is quite productive but not innovative at all. These establishments, by operating along the production chain of a very productive factory, enjoy a technological rent and are not incentivized to incur innovation efforts.

The limited co-agglomeration patterns, with few establishments outside the production chain, also reflect a shift in the entrepreneurial supply curve (Chinitz, 1961; Glaeser et al., 2015). We document this effect using population census data and a nationally representative household survey. Census data allow us to identify po-

as of 1950, controlling for vulnerability measures computed in a similar way and reflecting the geopolitical situation after the Sino-Soviet split of 1960.

${ }^{3}$ We identify the MRPs in a census of manufacturing establishments (see below) and can compare them with other firms: MRPs are about four times as productive as similar firms in the same sector and year.

${ }^{4} \mathrm{By}$ contrast, we find little support for negative spillovers along factor demand, most notably an underinvestment in human capital (Glaeser, 2005; Polèse, 2009; Franck and Galor, 2017) or favoritism and preferential access to capital (Fang et al., 2018; Harrison et al., 2019). 
tential distortions in the supply of entrepreneurs by investigating the composition of emigrants at the county level. We show that emigrants from treated counties are much more likely to be educated and to be self-employed at destination. These results are consistent with a continued supply of entrepreneurs that however find it more promising to export their skills than create enterprises in treated counties. Based on a module capturing values and aspirations, we then use survey data to show that respondents in treated counties are more likely to emphasize education and job prestige, and to aspire to higher-education degrees, and less likely to display individualistic values associated with entrepreneurship. This is line with limited prospects for entrepreneurs in a local economy dominated by the production chain of the MRP.

While the negative effect of specialization and over-industrialization on innovation and entrepreneurship is often highlighted in the policy debate, there is little work identifying the mechanisms that underpin the long-run response of the local economy. This is likely due to three empirical challenges.

First, identifying industrial spillovers in the long run requires exogenous variation in the initial distribution of large industrial units. In an ideal setting, actual project sites would have a natural set of counterfactual industry locations, e.g., a list of candidate locations as in Greenstone et al. (2010), and a well-identified exogenous component in the selection process among these locations. We emulate such a hypothetical setup in two steps. We rely on the historical site-selection criteria described in Bo (1991) to determine a set of suitable counties based on geographic fundamentals (e.g., market access and access to natural resources). We then exploit the ephemeral geopolitical context to isolate exogenous variation in the selection of hosting counties. The planning period coincided with (i) the immediate aftermath of the Korean War, in which Chinese "volunteers" intervened directly, and (ii) the short-lived Sino-Soviet Treaty of Friendship, Alliance and Mutual Assistance. Location choices were crucially influenced by vulnerability to air strikes from major U.S. Air Force (U.S.A.F.) bases and the shield provided by U.S.S.R. and North Korean bases. ${ }^{5}$ We construct an instrumental variable by penalizing travel time from enemy bases using proximity to allied bases. Following the Sino-Soviet split, the protective role of these allied bases became irrelevant for all subsequent strategic decisions, and we condition our analysis on this ex-post vulnerability to airstrikes. ${ }^{6}$

\footnotetext{
${ }^{5}$ Senior generals were directly involved in siting decisions to protect the state-of-the-art factories from enemy airstrikes, using intelligence maps of the U.S. and Taiwanese airbases (Bo, 1991). Historical U.S.S.R. documents report the same strategy to locate Soviet Science Cities out of the reach of enemy bombers (Schweiger et al., 2018).

${ }^{6}$ The set of protected locations became smaller, which called for directing new industrial investments to the interior in a policy called the Third Front Movement (see Fan and Zou, 2019).
} 
Second, the research requires high-quality data on economic activity spanning the pre- and post-industrialization periods. China and its rapid structural transformation allow us to cover both periods with measures of economic activity between 1950 and 2015, and these measures can be nested at the county level (about 2,400 in China). Aggregate data are available in the early stages of industrialization, with the 1953, 1964, 1982, 1990, 2000, and 2010 Population Censuses. In the recent period, we rely on a quasi-census of manufacturing firms, which we geo-locate at the postcode level and link with patent applications. ${ }^{7}$ These high-quality establishment data allow us to carefully reconstruct the local structure of production and possible linkages with the local MRP, i.e., (i) input-output linkages, (ii) technology closeness, and (iii) factor demand and factor market distortions. The data also allow us to study the effect of the treatment on competition and price-setting by computing establishment-level markups.

Third, the identification of spillovers across production units is not straightforward. With treatment heterogeneity, i.e., with MRPs operating different technologies to produce different products and drawing on different factor markets, a simple difference-in-differences procedure cannot be implemented: it would require us to observe the sub-population of firms likely to be affected in control counties. We specifically develop a two-step procedure to address this issue. In a first step, we stratify counties by their propensity to receive a Million-Rouble plant. In a second step, we run Monte-Carlo simulations and draw - for each control county - one treated county (and its MRPs) from the same stratum and hypothetically attribute the associated $\mathrm{MRP}(\mathrm{s})$ to the control county. The identification of spillovers through this procedure relies on a version of the Conditional Independence Assumption.

This paper is the first to infer spatial, negative agglomeration externalities in the long run through the observation of linkages between production units. The research contributes to the literature on agglomeration economies and urban growth, as reviewed in Duranton and Puga (2014), in two ways. First, we document the boom-and-bust cycle of industrial clusters in the absence of external, aggregate factors leading to a decline in the manufacturing sector, and in a developing country context. Few papers have followed industrial clusters over a period of structural transformation (Kim, 1995; Glaeser, 2005; Franck and Galor, 2017), which is important to understand their evolution (Henderson et al., 2001; Ciccone, 2002) and

\footnotetext{
${ }^{7}$ The National Bureau of Statistics "above-scale" annual establishment survey (1992-2008) constitutes a census of establishments (more specifically, "legal units") with annual sales in excess of RMB 5 million and of all state-owned firms. Our data further include information gathered from the China City Statistical Yearbooks during the period 1994-2013, the 2004 and 2008 Economic Censuses covering all firms of the secondary and tertiary industries, and nighttime luminosity (DMSP/OLS, 1992-2013).
} 
long-run impact on regions (Chinitz, 1961; Glaeser et al., 2015). Second, we explore the drivers of the decline of industrial clusters, by investigating (i) the changes in agglomeration spillovers that large industrial sites exert on the local structure of production and (ii) their effect on the supply of entrepreneurs. We develop a new strategy to estimate treatment spillovers across establishments in the presence of treatment heterogeneity. ${ }^{8}$ We provide the first evidence of large, negative spillovers of industrial clusters, an effect that more diversified industrial investments mitigate (Duranton and Puga, 2001; Faggio et al., 2017). The results point to the importance of between-industry technological spillovers as drivers of innovation and development in the long run (see Carlino and Kerr, 2015, for a recent review). ${ }^{9}$ To investigate the effect of industrial clusters on the supply of entrepreneurs (Chinitz, 1961; Glaeser et al., 2015), we rely on micro population census and survey data and show a decline in the supply of entrepreneurs and reduced entrepreneurial values.

The paper further contributes to a recent body of research on place-based policies, reviewed in Neumark and Simpson (2015), and including Busso et al. (2013), Kline and Moretti (2014), von Ehrlich and Seidel (2018), and Schweiger et al. (2018), by identifying the agglomeration spillovers operating in the long run. The study also relates to research looking at competing or concurrent spatial policies in China, e.g., the impact of Special Economic Zones and industrial parks (Wang, 2013; Crescenzi et al., 2012; Alder et al., 2016; Zheng et al., 2017) or the impact of the Third Front Movement (Fan and Zou, 2015). In contrast to most of these studies, we can precisely characterize treatment spillovers from observing all dimensions of treatment heterogeneity and micro-data at the establishment level.

Finally, our paper complements an important literature on transition economies by highlighting the externalities induced by the local presence of a large industrial champion. Studies in this literature have focused on the misallocation of resources across production units, in particular the role of credit constraints (Song et al., 2011; Buera and Shin, 2013), dispersion in factor productivity (Brandt et al., 2016; Hsieh and Klenow, 2009; Hsieh and Song, 2015), and labor market distortions (Brandt et al., 2013; Tombe and Zhu, 2015; Mayneris et al., 2018). One source of distortions is specific to the Chinese context. Brandt et al. (2016) observe wide dispersion in output per worker within the non-state sector across localities in China, which

\footnotetext{
${ }^{8}$ This empirical strategy could apply to most of the literature analyzing the spillovers of Foreign Direct Investment on domestic firms (Head et al., 1995; Aitken and Harrison, 1999; Konings, 2001; Smarzynska Javorcik, 2004; Haskel et al., 2007). We indeed rely on similar definitions of possible linkages/spillovers between the treatment and local firms: links through competition on goods markets, vertical linkages in the input/output matrix, competition on factor markets, etc.

${ }^{9} \mathrm{By}$ contrast, we find little evidence of increased competition for local resources (Falck et al., 2013; Franck and Galor, 2017).
} 
derives from "entry wedges" that are highly correlated with the share of stateowned enterprises (SOEs) in the local economy. These SOEs are indeed shown to benefit from privileged access to resources even after privatization (Harrison et al., 2019). Corruption and political favoritism may divert productive factors away from productive establishments (Chen et al., 2017; Fang et al., 2018), and pro-competition policies may be particularly effective (Aghion et al., 2015).

The remainder of the paper is organized as follows. Section 1 describes the historical context. Section 2 details the data and the empirical strategy. Section 3 presents empirical facts about the rise and fall of early-industrialized counties. Section 4 provides evidence about the mechanisms behind the relative decline of treated counties with more granular establishment-level data. Section 5 briefly concludes.

\section{Historical background and the "156" program}

The " 156 " program is a unique experiment to study agglomeration effects in the long run. The program constitutes a massive push shock in an otherwise agrarian economy (Lardy, 1987; Rawski, 1979); ${ }^{10}$ different types of factories were built thereby allowing us to identify treatment heterogeneity. The geopolitical context introduces unique exogenous variation in the decision to locate projects. The "156" program was unanticipated before 1950, and strategic considerations behind the opening and location of plants became irrelevant a few years later, after the Sino-Soviet Split.

\subsection{The historical context}

This section provides a brief account of the historical context; a comprehensive description can be found in Appendix B.

Sino-Soviet cooperation (1950-1958) Although Sino-Soviet cooperation was central in the first years of the People's Republic, it was not based on strong preexisting economic relations. In 1949, after decades of destruction through the SinoJapanese and Chinese civil wars, Chinese leaders studied the possibility of international economic cooperation to foster the development of heavy industry and transform China's agrarian economy. For geopolitical and ideological reasons, ${ }^{11}$ the

\footnotetext{
${ }^{10}$ The investment precedes the structural transformation of the Chinese economy by about 30 years and presents the features of a large counterfactual experiment off the equilibrium path.

${ }^{11}$ The regime's revolutionary agenda, American support for the Nationalist government in Taiwan in the aftermath of the civil war, the Western embargo (Zhang, 2001) and then the Korean War, in which China directly participated by sending troops, reinforced links between China and the Soviet Union. This policy was called "leaning to one side" (yi bian dao) by Chairman Mao in a famous speech ("On the People's Democratic Dictatorship") delivered on June 30, 1949.
} 
Chinese government engaged in economic cooperation with the Soviet Union to give China its own independent industrial system (Dong, 1999; Lüthi, 2010). The possibility of economic cooperation became credible after the Sino-Soviet Treaty of Friendship and Alliance of 1950, which included a large loan. In August 1952, Chinese Premier Zhou Enlai visited Moscow to formalize the involvement of the Soviet Union in the long-delayed First Five-Year Plan (1953-1957). The U.S.S.R. agreed to cooperate and assist China in the creation of state-of-the-art industrial sites, with the purpose of extending its influence in the region.

Sino-Soviet Split (1958-1960) Rapid ideological and geopolitical divergence precipitated a Sino-Soviet split that ended all cooperation between the two countries. The split formally unfolded in 1960 with (i) an abrupt termination of industrial collaboration and (ii) heightened military tensions. The termination of industrial collaboration materialized in the sudden withdrawal of experts and engineers from China, the repatriation of Chinese students from the U.S.S.R., and the cancellation of ongoing industrial projects. The only remnants of the short-lived Sino-Soviet alliance were 150 plants that had been already completed and were operational by 1960. The end of the military alliance also affected later industrial investment in China. Before the Sino-Soviet Split, proximity to military U.S.S.R. air bases would guarantee security against possible aerial attacks from the United States or from the Republic of China relocated in Taiwan. After the Sino-Soviet Split, U.S.S.R. air bases would be considered another threat, thereby explaining the peculiar features of later strategic decisions (e.g., the Third Front Movement).

\subsection{The "156" program}

An industrial collaboration As part of the First Five-Year Plan (1953-1957), the U.S.S.R. committed to assisting China in the construction of 50 industrial sites. In May 1953, 91 new projects were agreed on and an additional 15 in October 1954. Overall, about 150 state-of-the-art factories would be constructed between 1953 and 1958; the factories were huge investments and benefited from economic and technological assistance from the Soviet Union.

The U.S.S.R. actively participated in the design and construction of these factories. First, the economic aid from the U.S.S.R. extended beyond large loans; the U.S.S.R. provided more than half of the required equipment. ${ }^{12}$ Second, the collabo-

\footnotetext{
${ }^{12}$ As a payment, China was to give 140,000 tons of tungsten concentrate, 110,000 tons of tin, 35,000 tons of molybdenum concentrate, 30,000 tons of antimony, 90,000 tons of rubber and other produce including wool, rice or tea. Some low-skilled workers were also sent to Siberia.
} 
ration involved the exchange of information, human capital, and technology. During the peak of the cooperation, between 1953 and 1956, 20,000 scientific, industrial and technical experts from the Soviet Union lived and worked in China to design the construction of factories and rationalize production (Zhang, 2001; Wang, 2003). In order to build capabilities, 80,000 Chinese students were trained in Soviet universities and technological institutes. While some blueprints were destroyed, the existing technology could be imitated and represented a large shift in the technological frontier for an agrarian economy (Bo, 1991). ${ }^{13}$

Chinese scholars credit the "156" program with having (i) invested in basic sectors such as the energy and steel industries and laid the foundations for the development of other industries, (ii) boosted production capacity and shifted the technological frontier, and (iii) promoted a more even spatial development by industrializing central and western provinces (Dong and Wu, 2004; Zhang, 2009; Shi, 2013; He and Zhou, 2007). While these factories are known as the "156" in China, we rather refer to them as the "Million-Rouble Plants" (MRPs). Indeed, at the time of the Sino-Soviet Split, six factories were not yet viable and were forcefully closed; only 150 plants had been completed and were operational by 1960 .

Location decisions The MRPs were regarded as iconic firms and planners put much thought in siting decisions. First, planners selected locations using economic criteria. These suitability criteria, detailed in Bo (1991), are: (i) connection to the transportation network and access to markets, (ii) access to natural resources through existing roads and rail, and (iii) belonging to an agrarian province, as the investments were seen as an opportunity to smooth the spatial distribution of income. We will use these criteria to identify a relevant control group.

However, this period was an era of heightened geopolitical tensions that culminated in the Korean War - where U.S. soldiers and Chinese "volunteers" directly confronted. Planners were concerned that the brand-new plants might become the target of enemy attacks. The decision process involved senior military officials to decide where factories should be built, accounting for the locations of enemy and allied airbases. Major enemy airbases in Japan, South Korea and Taiwan were remnants of the major U.S. airbases used during World War II, the Korean War, and bases used by the United States Taiwan Defense Command. Most of the Chinese territory was in the range of U.S. strategic bombers; the decision process thus heavily relied on the locations of allied airbases, mostly in the Soviet Union and North

\footnotetext{
${ }^{13}$ The last 15 projects agreed on in 1954 even benefited from state-of-the-art equipment that few Soviet factories enjoyed (Goncharenko, 2002), allowing China to make the most of Gerschenkron's (1962) "advantage of backwardness" (Tang, 2009).
} 
Korea, able to intercept them. As explained earlier, the Sino-Soviet split made this location criterion redundant.

Million-Rouble Plants and economic growth For the first 30 years of their existence, the MRPs developed in a planned economy. These factories and their local economies were fueled by the provisions of the plan. Factor movement was not free, and if more workers or capital could be productively employed, the plan would reallocate resources. The command-economy era as a whole will be considered as the treatment; treated counties enjoyed a head start at the onset of the reform period.

Reforms to deregulate the economy were introduced in the 1980s. Private firms could be set up and a dual price system allowed market transactions alongside the old quota requirements. In the 1990s, restrictions on labor mobility were gradually loosened, and migration began to rise as a major feature of Chinese economic growth. Most MRPs successfully adapted to the market economy and remained leaders in their respective industries. ${ }^{14}$ These industrial clusters have diversified their activities, their products ranging from computer screens to carrier-based aircraft.

\section{Data and empirical strategy}

This section describes data sources, the empirical strategy and provides some descriptive statistics.

\section{$2.1 \quad$ Data}

One requirement for estimating the long-term agglomeration effects of the opening of large plants is to collect local data on economic production, ideally covering 60 years from 1950 to 2015. In this paper, we mobilize the following main data sources to shed light on the short- and long-term effects of the "156" program: (a) information on the Million-Rouble Plants and their evolution over time, (b) countylevel data on population and production (1953-2015), (c) establishment-level data in recent years (1992-2008), linked with patent applications and other product-level information (factor intensities and technological content), and (d) information on entrepreneurship from survey and population census data, and administrative data on firm creation.

\footnotetext{
${ }^{14} \mathrm{~A}$ small number of firms went bankrupt. The first firm forced into bankruptcy (in the late 1970s) was a coal mine, because of resource depletion. Since then, eight other factories have been closed, all coal or non-ferrous metal mines. Two other firms, a paper mill and a former military electronics plant, were partly restructured and continue to operate. Note that, when construction plans were made in the 1950s, most plants were built in the city center. As pollution issues and the need for expansion had not been anticipated, nine plants were moved to the suburbs.
} 
The Million-Rouble Plants In order to define the local treatment induced by the presence of an industrial cluster, we collect information on the geo-coded location of the factories that constitute the " 156 " program, information on the timing of construction, the initial investment, the original industry, and the evolution of production over time. These pieces of information are extracted primarily from Bo (1991) and Dong and Wu (2004), and from historical archives, while the recent activity of these factories is retrieved using establishment-level data (see Appendix F).

County-level data We rely on various data sources that are nested at the county level. We first use county gazetteers, which provide information on industrial and agricultural production in the command-economy era, as well as information on population, broken down by education, age, gender, and broad sector of activity. ${ }^{15}$ Second, we use Population Censuses in 1953, 1964, 1982, 1990, 2000, and 2010. The 1953 data only provide population and household counts, but subsequent censuses capture the agricultural status of households. At the time of the command economy, the household registration (hukou) type is a faithful reflection of both activity and the environment of residence. This piece of information offers us the opportunity to start tracking the evolution of urbanization and economic sectors from 1964 onward. Additional county-level information is available in 1982, most notably a disaggregation of employment by broad sectors and measures of output. In 1990, precise data are collected on the sector and type of employment and occupation, as well as on housing and migration, a phenomenon that mostly involved agricultural-hukou holders moving to cities in search of better earning opportunities. The 2000 and 2010 Censuses further include information on the place of residence five years earlier, timing of the last migration spell, reason for migrating, and place and type of household registration. ${ }^{16}$

Data collected by statistical offices - gazetteers, censuses, surveys, and yearbooks rely on official administrative divisions at the time of data collection. County boundaries, and to a lesser extent prefecture boundaries, are subject to frequent and sometimes substantial changes in China. To deal with this issue, we use the 2010 administrative map of China as our benchmark and re-weight the data collected in other years to match the 2010 borders. More precisely, we overlay the 2010 map with the map for every other year $y$ and create a new map with all the polygons

\footnotetext{
${ }^{15}$ County gazetteers are currently being digitized and harmonized as part of the China Gazetteer Project-see https://www. chinagazetteer.com/.

${ }^{16}$ Data from Statistical Yearbooks (1994-2013) are used to shed light on the effect of MRPs on local wages. These data also allow us to capture environmental disamenities related to the presence of a MRP (e.g., ground pollution readings).
} 
defined by the 2010 and year- $y$ divisions. We then compute the area-weighted value of the variable of interest for each polygon and collapse the values at the level of the 2010 counties.

Establishment-level data We rely on the National Bureau of Statistics (NBS) "above-scale" manufacturing firm data, which constitute a longitudinal census of all state-owned enterprises (SOEs) and of all non-SOEs as long as their annual sales exceed RMB 5 million. ${ }^{17}$ These data cover the manufacturing sector over the period 1992-2008 and contain a wealth of accounting information at the level of "legal units." A legal unit can be a subsidiary of a firm, but has its own name and is financially independent (Brandt et al., 2014). Nearly $97 \%$ of legal units in our data corresponded to single plants. We will refer to these units as establishments. We use the link provided by He et al. (2018) to match establishments with patent applications, and distinguish three types of patents (utility, invention, and design). We further complement the establishment data with product-level information, in particular a benchmark input-output matrix (United States, 2000), measures of technological closeness using patenting in the United States (Bloom et al., 2013), and the revealed factor intensity using the factor endowments of countries producing each good (Shirotori et al., 2010).

Entrepreneurial supply We rely on two data sources. A first data source is the China Family Panel Survey (CFPS), a nationally representative survey of about 15,000 households carried out by the Institute of Social Science Survey at Peking University. ${ }^{18}$ CFPS contains modules on aspirations and world outlook, in particular on effort and individualism, along with socioeconomic data. These modules provide us with rare information on entrepreneurial spirit.

A second data source is the firm registry of the Administration for Industry and Commerce, which can shed light on the migration patterns of entrepreneurs in treated and control counties. These administrative data cover the universe of Chinese firms - see Shi et al. (2018) for a description. They contain information on the paid-in capital, date of creation, years in operation, and location of the firm, as well as the origin or place of registration (hukou) of the firm's legal representative.

\footnotetext{
${ }^{17}$ Unique establishment identifiers can be retrieved thanks to the algorithm designed by Brandt et al. (2014) and extended in Imbert et al. (2018), thereby allowing us to construct a panel of firms spanning the period 1992-2008.

${ }^{18}$ CFPS is representative of $95 \%$ of the Chinese population-Inner Mongolia, Hainan, Ningxia, Qinghai, Tibet, and Xinjiang are not covered. CFPS consists of three waves: a baseline in 2010, and two follow-up surveys in 2012 and 2014; we focus on 2012 and 2014, when our modules of interest are included. Please refer to www.isss.edu.cn/cfps for further information about CFPS.
} 
For richer individual-level data, we rely on the 1\% Population Survey of 2005, often referred to as the "2005 Mini-Census," to compare the profiles of emigrants from treated and control counties. Key variables available in the Mini-Census include the level of education, employment status (with a distinction between self-employed and employers), income, and place of registration at the county level.

\subsection{Empirical strategy}

This section describes the two steps of the baseline empirical strategy. We first select counties based on their suitability for hosting a Million-Rouble Plant. We then discuss how we construct a measure of vulnerability to enemy bombings and use it to explain the choice of industry locations among suitable counties.

Propensity score and suitable locations We isolate a group of suitable counties by implementing a propensity-score matching based on the eligibility criteria described in Bo (1991). A crucial criterion is market access and connectedness to the transportation network. In the baseline matching procedure, we rely on an indicator variable that equals 1 if a county belongs to the provincial capital, ${ }^{19}$ county population at baseline (measured by the 1953 Census) and county area to capture the former. We reproduce the transportation network in China at the time of the First Five-Year Plan using the existing railroad network in 1948 (see the left panel of Figure 1), and we construct a measure of proximity to a railroad hub to model connectedness. A second criterion is access to raw materials: coal, mostly, but also ore and coke deposits. We create a fine grid over China, allowing for different costs of crossing a cell depending on the means of transportation available. ${ }^{20}$ We then calculate the minimum travel cost from the closest mineral field for all points through the existing transportation network and collapse it at the county level. The spatial distribution of transport costs to coal fields is displayed in the right panel of Figure 1. As apparent in Figure 1, the historical development of the railway network and the location of natural resources induces that a crescent of counties are prone to receiving large industrial infrastructure. This crescent, located a few hundred

\footnotetext{
${ }^{19}$ We consider a county as part of the provincial capital if it belongs to the prefecture in which the provincial capital was located at the time of the First Five-Year Plan.

${ }^{20}$ We derive the cost of transporting goods on roads by exploiting the road structure in 1962 and assuming the same cost ratio as Glaeser and Kohlhase (2004), who estimate costs of 28 cents per ton mile for trucks and 3 cents per ton mile for rail in the United States at the end of the $20^{\text {th }}$ century. The relative cost of transporting goods through cells that lie neither on a road nor on a railroad line is set at twice the transport cost by truck (Fogel, 1964). Waterways are omitted from the cost-minimization procedure, as only $2.5 \%$ of total freight traffic was carried out by barges (Rong, 2012).
} 
kilometers from the Eastern coasts and borders, may be interpreted as a Second Front for industrialization; the later Third Front Movement will go deeper into the hinterland - a decision that will be rationalized by our empirical strategy.

Although they do not feature among the list of explicit determinants, other geographical and economic factors may have entered siting decisions, e.g., distance to major ports, and we condition our analysis on some of these factors susceptible to affect long-term economic growth in robustness checks. ${ }^{21}$

We regress the treatment, i.e., being in the close neighborhood of one of the MRPs (within 20 kilometers), on the location determinants described above, $\mathbf{H}_{c}$, to generate a propensity measure $P_{c}=P\left(\mathbf{H}_{c}\right)$ for each county. We define the set of suitable locations $C=\left\{c_{1}, \ldots, c_{N}\right\}$ by matching treated counties with the five nearest neighbors in terms of the propensity $P_{c}$. We restrict the matching procedure to counties with a measure $P_{c}$ in the support of the treated group. We impose that matched control counties be selected outside the immediate vicinity of treated counties, in order to avoid spillover effects into the control group. In the baseline, we exclude counties whose centroids lie within a 4-degrees $\times 4$-degrees rectangleroughly 2-3 times the size of the average prefecture - centered on a treated county. Figure 2 shows the distribution of propensity scores in the group of treated counties and the control group (left panel), and the balance of a few matching variables within the whole sample and within the selected sample of suitable counties (right panel). The geographic dispersion of the treated and control counties is shown in Figure 3: most treated and control counties are located along this "Second Front" crescent, treated counties are however less likely to be located in Central China.

Vulnerability To isolate exogenous variation in the decision to select counties, we construct measures of vulnerability to air strikes from major U.S. Air Force (U.S.A.F.) and Taiwanese bases, accounting for the presence of allied bases acting as a shield (see Appendix C).

To this end, we geo-locate active U.S. Air Force bases and Taiwanese military airfields (enemy airbases), as well as major U.S.S.R. and North Korean airbases (allied airbases). To account for the presence of allied airbases, we penalize travel

\footnotetext{
${ }^{21}$ It is worth noting that siting decisions were certainly informed by little more, and perhaps much less, than our GIS measures. The lack of a well-functioning statistical administration, which explains the delay in devising the First Five-Year Plan (1953-1957), put severe constraints on policy making in the early years of the People's Republic of China. In the current strategy, few county characteristics are targeted thus leaving many variables available for a balance test. By contrast, more variables could be used to refine the initial matching, thereby leaving few characteristics to compare across treatment and control groups in an "over-identification" check. We will show that our findings are not sensitive to small variations around the baseline matching procedure.
} 
time for enemy bombers in the vicinity of U.S.S.R. and North Korean bases. The procedure, discussed in Appendix C, is disciplined by the technical characteristics of jet fighters at that time, most notably their range, and produces a continuous measure of the cost for enemy airplanes of traveling through any given point of the Chinese territory. We compute the minimum travel cost from each active U.S.A.F. or Taiwanese base to each county and define the measure of vulnerability $V_{c}$ as the minimum of penalized distances across all major enemy bases.

We report an illustration of the spatial variation in the output of this procedure, vulnerability to aerial attacks, in Figure 4: Panel A shows vulnerability in 1953, i.e., before the Sino-Soviet split, and Panel B shows vulnerability after the split, in 1964. Military concerns should favor the Northeast at the expense of Central China in 1953; the set of suitable and protected locations however becomes much smaller after 1960, and investment during the Third Front had to be targeted toward interior provinces. Our empirical strategy uses the pre-split measure as an instrument for factory location decisions, conditioning for the post-split measure, thereby using the ephemeral alliance between China and the U.S.S.R. as the main source of identification (Figure 4, Panel $\mathrm{C}$ shows the residual variation in vulnerability to air strikes in treated and control counties).

For $V_{c}$ to be a valid instrument, it must affect the outcome only through the treatment. Any fortuitous correlation between $V_{c}$ and the outcome would jeopardize the identification strategy. A major challenge to the exclusion restriction comes from the spatial correlation in southern China between vulnerability and growth in the reform era. We deal with this concern through robustness checks (controlling for distance to enemy airbases, i.e., to Taiwan, North Korea, and Japan; controlling for distance to the coast; controlling for access to sea ports as a proxy for international market access; excluding the Pearl River Delta, which spearheaded Chinese growth; excluding all of southern China). Figure 4, Panel C already shows that conditional on the main controls, the instrument is largely uncorrelated with distance to the shore. This is confirmed by Figure 5, where we plot the residual from a regression of $V_{c}$ on the baseline controls against distance to the coast.

First stage Figure 6 provides a representation of the relationship between the unconditional and the conditional proximity to U.S. and Taiwanese airbases and factory location choices. Although we find both treated and control counties at most levels of vulnerability, the distribution of travel cost across treated counties has a much fatter right tail than that of the control group, which shows that factories were preferably established at a (penalized) distance from enemy threats. 
The relationship between the treatment and vulnerability measure constitutes the first stage of our empirical specification. Table 1 shows that vulnerability to enemy bombings is a crucial factor in the location choice. One additional standard deviation in penalized distance from enemy bases increases the propensity to host a Million-Rouble plant by about 26 percentage points among suitable counties. The average difference in vulnerability between treated and control counties is about three quarters of a standard deviation; our instrument thus explains $0.75 \times 26 \approx 20 \%$ of the allocation of MRPs among suitable counties. Table 1 displays three specifications, one without any controls (column 1), one with the propensity controls only (column 2), and one with the full set of controls (baseline specification, column 3). All specifications are restricted to the set of treated and control counties defined by matching on access to natural resources and the additional economic and geographical determinants. The full set of controls is used to condition the analysis on characteristics that may directly affect outcomes of interest in the second stage; it is however reassuring that the first stage is not dependent on their inclusion.

Importantly, the treatment is not correlated with vulnerability measures as computed in 1964 and 1972, and vulnerability to aerial attacks in 1953 does not strongly correlate with later place-based policies (see Appendix Table A2 and A3 for these placebo first stages).

Benchmark specification Let $c$ denote a county and $T_{c}$ the treatment variable indicating whether a county hosts a factory. We estimate the following IV specification on the sample of suitable counties:

$$
Y_{c}=\beta_{0}+\beta_{1} T_{c}+\mathbf{X}_{c} \beta_{\mathbf{x}}+\varepsilon_{c}
$$

where $T_{c}$ is instrumented by $V_{c}$, and $Y_{c}$ is a measure of economic activity at the county level. The controls include the propensity controls, a set of propensity score dummies (stratifying the sample along the propensity score), and the following additional controls: travel cost to major ports, proximity to cities in 1900, proximity to Ming-dynasty courier stations, distance to military airfields, and the post-split vulnerability to air strikes. Standard errors are clustered at the level of 4 -degree $\times$ 4-degree cells.

A key assumption underlying the empirical strategy is that the instrument has no effect on outcomes of interest other than through the location of the Million-Rouble plants. We now discuss possible concerns with this assumption. First, the respective locations of military bases could have influenced investment at later stages of the Chinese structural transformation. Conditioning by the same vulnerability to 
enemy raids, but after the Sino-Soviet Split and the start of the Vietnam War rebalanced the geographic distribution of military power in the region, should reduce this concern. We also provide a sensitivity analysis by controlling for later spatial policies and large shocks (e.g., Third Front Movement, Cultural Revolution, Special Economic Zones, etc.). Second, vulnerability may correlate with unobserved amenities, which would explain both the decision to locate factories and later patterns of economic growth. For instance, China's Southeast was considered extremely vulnerable but widely benefited from the opening of Chinese ports to trade in the reform era. ${ }^{22}$ Such a violation of the exclusion restriction would induce a spurious negative correlation between economic growth and the presence of " 156 "-program industries in the reform period. To deal with this concern, we will run a series of robustness checks, most notably excluding a buffer around the Pearl river delta, excluding all Chinese counties below a certain latitude, or controlling for distance to the coast. Third, we can repeat our exercise by replacing actual factories by the unfinished projects. ${ }^{23}$ While the first stage still applies, the second stage shows no differences between placebo locations and other suitable locations.

\subsection{Descriptive statistics}

The Million-Rouble Plants expanded and modernized the Chinese industry in a wide range of sectors, but mostly heavy, extractive, and energy industries (e.g., coal mining or power plants, see Table 2). ${ }^{24}$ Construction started between 1953 and 1955, and was achieved at the latest in the first quarter of 1959. The last two columns of Table 2 show planned and actual investment; the figures attest the scale of the program for an agrarian economy like China in the 1950s. The average planned investment by factory was about 100,000,000 yuan, which amounted to 15,000,000 Soviet roubles in 1957 (\$120,000,000 in 2010 U.S. dollars); total investment was of the order of a fifth of annual production in 1955.

Table 3 provides key descriptive statistics for treated and control counties. About $5 \%$ of Chinese counties are defined as being treated, and we use $15 \%$ of Chinese counties as suitable control counties in our baseline specification. As expected from a context of heightened international tensions in Asia following the Korean War,

\footnotetext{
${ }^{22}$ Note, however, that the vulnerability measure does not overlap with the coast-interior divide that characterizes the spatial distribution of economic activity in China. Some factories were indeed set up on the coast, first and foremost in Dalian, but not on the southern shore, too exposed to American or Taiwanese strikes.

${ }^{23}$ In this exercise, we exclude counties that hosted one of the completed and operational factories.

${ }^{24}$ The "156" program follows the "Russian model" of industrialization (Rosenstein-Rodan, 1943), with coordinated and large investments across industries to modernize agrarian economies. These upstream factories were expected to irrigate the economy downstream.
} 
treated counties are located at a much greater distance from U.S.A.F. and Taiwanese bases. The difference in mean penalized distance between treated places and the average Chinese county is about $75 \%$ of a standard deviation. Note, however, that control and treated counties do not differ markedly in their exposure to enemy raids after the Sino-Soviet split.

Differences in terms of population are small at baseline (1953), jump in 1964 and stabilize somewhat afterwards. Descriptive statistics about urban registration show a similar gradient between treated and control locations, albeit more persistent. Households in treated counties are more likely to hold an urban registration even after the reform. These differences are, however, not indicative of economic activity from 1990 onward, given the large number of rural migrants working in cities.

The bottom panels of Table 3 describes possible differences in matching variables and additional controls used in the baseline. Consistent with the propensity matching procedure, differences in topography and connectedness are less pronounced among suitable locations. Treated counties exhibit slightly lower travel costs to coal, coke and ore deposits. These differences are nonetheless accounted for by propensity-bin dummies and matching weights in Specification (1). Two historical control variables appear as being important in explaining the allocation of treatment, even though they do not explicitly feature among location criteria: proximity to cities in 1900 and proximity to Ming stations. We thus include these variables as controls in the baseline specification.

\section{The rise-and-fall pattern}

This section presents the implications of early industrialization at the county level.

\subsection{Baseline results}

The influence of the Million-Rouble plants on local trajectories spans two different periods: the rise in the command-economy and the fall during the reform period. ${ }^{25}$

The rise We first describe empirical facts about the local treatment effect of industrial clusters in 1982; the analysis and the choice of outcomes are unfortunately limited by the availability of information at the county level. Table 4 shows OLS (Panel A) and IV estimates (Panel B) of the relationship between the presence of a

\footnotetext{
${ }^{25}$ Note that reforms in the non-agricultural sector were introduced gradually. Private firms were allowed to develop and compete with state-owned enterprises (SOEs) from the mid-1980s onward, which was instrumental in introducing market discipline in state-owned enterprises. Nonetheless, the large privatization wave did not start until the 1990s.
} 
MRP and population, share of urban residents, output per capita, and the employment share in industry (in 1982 and in 2010).

We find that industrial investment under the " 156 " program has a positive and significant impact, albeit small, on population in the earlier period. Treated counties are $22 \%$ more populated than control counties (column 1, Panel B). The treatment effect on urbanization is much larger; the share of the population that has nonagricultural household registration is about 35 percentage points higher (column 2, Panel B). The impact of the MRPs shows a large reallocation of labor, which could be interpreted as evidence of structural transformation and urbanization. The higher share of urban residents is associated with a much higher output per capita, and a higher industry share in the local economy (columns 3 and 4, Panel B). GDP per capita is more than twice larger in treated counties; the employment share in industry is 24 percentage points higher. The magnitude of these differences is far beyond the mere output of the average MRP, indicating that counties are richer and more developed - the effect is equivalent to the difference between the median and the top $10 \%$ of the control-group distribution.

A few remarks are in order. First, the IV estimates are larger than the OLS estimates, possibly reflecting that places selected to host a MRP were less likely to host major industrial developments prior to the First Five-Year Plan (Bo, 1991). Second, the extent of the short-run impact of industrial clusters may have limited external validity. Before the advent of the reforms, the government would instruct workers where to live and where to work to accommodate rising demand for labor and ensure the growth of the plants and local economy. ${ }^{26}$ Changes in labor allocation mostly reflect government intervention, which is likely to temper agglomeration effects. The population increase, while larger than the expected labor force of the MRP itself, remains limited and probably lags behind labor demand in treated counties.

To summarize the impact of the "156" program between 1953 and 1982, we find a moderate effect on urban population, but a very large effect on the local structure of production. The substantial productivity gap between treated and control counties indicates that treated areas enter the subsequent period with a substantial head start. Lower mobility costs and the liberalization of the economy should allow agglomeration economies to operate, and one could expect treated counties to grow even further apart from the rest of the economy. As we see next, we find the opposite.

\footnotetext{
${ }^{26}$ While some free movement of labor still occurred after the advent of "New China" in 1949, mobility was subject to authorization from the late 1950s onward. The government had tightened its grip on labor movement in the wake of the Great Leap Forward, when famines threatened the sustainability of urban food provision systems.
} 
The fall There is a full catch-up between 1982 and 2010 (see Table 4). We find that population is still higher in treated counties (column 1, Panel B); treated locations also continue to have a significantly higher share of urban population (column 2, Panel B). In stark contrast with the treatment effect in 1982, however, output per capita and the industry share are now similar or even lower in treated counties (columns 3 and 4, Panel B). The significant gap in industrialization before the transition has thus fully eroded: treated counties are equally productive as control counties and the employment share in industry is 13 percentage points lower. This fast reversion to the mean does not result from a swift decline in employment in the Million-Rouble plants themselves. ${ }^{27}$

A further illustration of the catch-up between 1982 and 2010 is provided in Figure 7 . The left panel shows a rapid and linear drop in the industrial employment share, from +24 to -13 percentage points relatively to control counties. Treated counties keep, however, some marks of their early industrialization. The right panel shows that the share of urban area, as captured using recognition of impervious surfaces on satellite images, remains higher in treated counties. ${ }^{28}$ Before turning to the mechanisms underlying this puzzling stylized fact, we provide a series of robustness checks.

\subsection{Sensitivity analysis}

Matching and weights We start by analyzing variation along the baseline specification (Appendix Table A4). In Panel A, we run a simple OLS regression with province-fixed effects on the whole sample of counties in China. The identification thus relies on a comparison of treated counties with their immediate neighbors. The treatment effect in 1982, and the reversal of fortune in 2010, are found to be slightly smaller than in the baseline specification, possibly reflecting spatial spillovers. In Panels B to E, we revert to the IV specification on the sample of counties selected through a matching procedure. In Panel B, we add proximity to Ming stations, distance to military airfields and access to the main trading ports to the matching process. In Panel $\mathrm{C}$, we restrict the matching process to a small set of variables: travel cost to coal mines, proximity to a rail hub, whether the county is a provin-

\footnotetext{
${ }^{27}$ Appendix F provides a comparison between the MRPs and similar "above-scale" manufacturing establishments within treated counties. Appendix Tables F1 and F2 show that MRPs account for a moderate share of their local economies and are extremely productive. Total Factor Productivity, measured following the procedure developed in Imbert et al. (2018), is four times as high in Million-Rouble plants.

${ }^{28}$ There seems to be an inflection point around 2000, which corresponds to the opening of the Chinese economy and the acceleration in manufacturing growth: control counties appear then to catch up with treated counties.
} 
cial capital, population in $1953(\log )$, and county area $(\log )$. In Panel D, we use a one-to-one matching procedure without replacement between treated and control counties. Finally, Panel E doubles the exclusion zone around treated counties (see Section 2). The main result, i.e., the large difference in GDP per capita in 1982 and the subsequent catch-up, is qualitatively unchanged relatively to the baseline.

In the baseline specification, observations are weighted by matching weights accounting for the extent to which the distribution of propensity scores coincides between treated and control counties. Panel F of Appendix Table A4 provides the main estimates without any weights; they are similar to the baseline estimates.

Exclusion restriction We then provide a sensitivity analysis designed to support the exclusion restriction hypothesis (Appendix Table A5). There are two empirical concerns with Specification (1) and the rise-and-fall pattern: (i) the baseline specification does not account for the evolution of Million-Rouble plants themselves; and (ii) the specification relies on a geographic instrument that may correlate with the later spatial developments of the Chinese economy. While we already document the healthy condition of Million-Rouble Plants in recent decades (see Appendix F), we further provide a robustness check in Panel A of Appendix Table A5 by excluding treated counties with either a closed or displaced MRP.

The rise and fall of treated counties may reflect a very abrupt take-off in control counties, for instance related to general patterns of development in Southeast China. We thus exclude a large buffer of (mostly control) counties within a 500-km buffer around the Pearl river delta (Panel B), and we exclude all counties below the 28-degree latitude (Panel $\mathrm{C}$ ). These robustness checks show that our findings are not driven by the closure of unhealthy MRPs in some treated counties or by the correlation between our instrument and patterns of the overall development of the Chinese economy. We further investigate the role of geographic characteristics in Panels D to G. We add to Specification (1) the following variables: distance to the coast (Panel D, to capture a comparative advantage in an exporting economy), elevation, ruggedness, indicators of soil quality-lacustrine plains, sand hills, tidal marshes, - and expected yield — rice, maize, wheat-(Panel E). The geographic conditions do not explain the main empirical fact.

The relative fall of treated counties may be due to the implementation of the Third Front Movement (Fan and Zou, 2019) or other place-based policies in control counties (Special Economic Zones or industrial park policies, as in Wang, 2013; Crescenzi et al., 2012; Alder et al., 2016; Zheng et al., 2017), or severe disruption due to pre-transition policy shocks in treatment counties, e.g., during the Cultural 
Revolution. We control for such policies and events in Panel F. Beyond these emblematic spatial policies, the regime could have favored certain counties due to their strategic location, and these further investments may correlate with the vulnerability instrument. We already control for the general vulnerability to air strikes in 1964; we separately add the vulnerability to Soviet air strikes in 1972. Neither alternative policies nor alternative measures of vulnerability affect our estimates.

Other outcome measures We consider alternative outcome measures in Appendix Table A6. In Panel A, we extract a few additional variables from the 1982 Census, i.e., labor force participation, illiteracy rate, and the male-to-female ratio. The illiteracy rate is much lower in treated counties (16 percentage points). There are no sharp differences in the male-to-female ratio, which shows that selected immigration, if any, was not strongly tilted toward males. In Panel B, we shed additional light on the nature of the rise-and-fall pattern: we document the allocation of workers across sectors in 1990 and 2010. The observed difference in household registration (see Table 4) does reflect a difference in employment shares across sectors of the local economy: the employment share in agriculture is 27 percentage points lower in treated counties. The "released" labor force is equally absorbed by industry and services. In particular, a significant share of workers in the service sector are allocated to distribution and transportation (results not shown), two sub-sectors very likely to intervene in the production chain of a MRP. The magnitude of these estimates is large: the local allocation of workers in treated counties resembles the aggregate Chinese economy after the transition. In 2010, however, treated counties are less industry-intensive, a result mostly explained by a higher prevalence of services (distribution and transportation).

Panel C of Appendix Table A6 provides additional support for the slowdown of economic activity in treated counties. We use remote sensing in order to derive alternative measures of living standards at the county level, and resort to night-time luminosity between 1993 and 2012 ("Average Visible, Stable Lights, \& Cloud Free Coverages") as a complement for census-based measures. Our findings show that luminosity is three times higher in treated counties in 1993, and a large share of this head start disappears by 2012 (column 2).

Finally, we analyze the role of government expenditures and revenues in Panel D of Appendix Table A6. We do not find a very strong long-term impact on local government expenditures in 2010, but government revenues are significantly lowerpossibly reflecting a combination of lower economic activity and lenient local taxation. This discrepancy between expenditures and revenues can only be sustained 
temporarily, or it would strongly affect the asset position of local governments. We do not find large differences in savings, which indicates that the gap appeared rather recently.

\section{Mechanisms behind the fall of treated counties}

This section analyzes the possible spillovers exerted by a MRP on the local structure of production at the county level and on the supply of entrepreneurs. We study the treatment effect on the structure of production in three steps. In a first step, we analyze the structure of firm production in the average establishment. In a second step, we refine the analysis of the production structure by looking at treatment heterogeneity across establishments of the same county. This exercise allows us to explore various aspects of the tangle of economic relationships across establishments, most notably spillovers along the production chain. In a third step, we investigate the effect of hosting a MRP on the local supply of entrepreneurs.

\subsection{Structure of firm production in the average establishment}

The analysis of the structure of production relies on measures of factor productivity at the establishment level, identified using industry-specific CES production functions and an exogenous labor supply shifter (see Imbert et al., 2018, and Appendix D for a description of the empirical strategy), on patents linked to establishments (He et al., 2018), and on markups computed following De Loecker and Warzynski (2012) (see Appendix D for a comprehensive description of the method).

Average treatment effect In this section, we describe the treatment effect on the structure of production using a selection of outcomes, and we leave the detailed analysis of factor use, factor productivity, firm characteristics, investment and subsidies, patenting behavior, and price setting in Appendix E. In Table 5, we extend Specification (1) at the establishment-level, consider all establishment $\times$ year observations between 1992 and 2008, and regress a measure of production on the treatment $T_{c}$, instrumented by $V_{c}$. In all these establishment-level specifications, we clean for year interacted with 4-digit industry fixed effects and for year interacted with firm type: our results are orthogonal to aggregate industrial trends and to the demise of public establishments. We also exclude the MRPs from the sample.

Factor use is different in treated and in control counties (columns 1 and 2): establishments in treated counties are more capital-abundant than in control counties; real capital is $40 \%$ higher, while employment is $30 \%$ higher. Labor cost sharply dif- 
fers in treated counties. We find that the average compensation per employee is about $32 \%$ lower in treated counties (Table 5, column 3). These findings point to a downward shift in labor supply in treated counties compared to control counties.

Total factor productivity is $30 \%$ lower in treated counties than in control counties (Table 5, column 4). ${ }^{29}$ This finding could either indicate that the treatment generates differences in technology adoption or differences in price setting between control and treated counties. We investigate these two aspects next. While we distinguish three patent categories in Appendix E (design, innovation, and utility - the latter categories being the most relevant to capture technological progress), we only report the treatment effect on the total number of registered utility patent applications in column 5 of Table 5 . We find that establishments in treated counties produce fewer patents. The treatment effect is of the order of magnitude of the yearly number of patents produced in the average establishment: very few patents are registered in treated counties. ${ }^{30}$ Finally, as shown in column 6 of Table 5, the TFP effect cannot be explained by markups; they are on average higher in treated counties: the probability for a firm to charge a markup above median in a given year and 4-digit industry is 13 percentage points higher in treated counties.

Compositional effects We provide a comprehensive analysis of compositional effects in Appendix E, in which we analyze how differences in production structure may reflect differences in the industrial fabric, differences in the ownership structure, or the presence of establishments at different stages of their life cycle. We summarize these findings below.

The previous results cannot be attributed to compositional differences induced by the presence of public enterprises, subsidized establishments (Harrison et al., 2019), or young firms. Indeed, (i) controlling for the exact type of an establishment (ownership structure) does not change the main insight conveyed by Table 5 . (ii) Public establishments in treated counties are not relatively less innovative or less productive than in control counties. If anything, their likelihood to register a patent and their total factor productivity are larger.

Dynamics The empirical facts shown in Section 3 point to a relative slowdown of economic activity in treated counties between 1982 and 2010. The previous evidence

\footnotetext{
${ }^{29}$ Labor cost and factor productivity appear to be low in treated counties, but dispersed (see Appendix E and Appendix Table E2).

${ }^{30}$ Controlling for the local industry structure is innocuous for factor productivity and factor use but quite important for patenting behavior. Indeed, the presence of the $\operatorname{MRP}(\mathrm{s})$ tilts the the local industrial fabric toward innovative sectors; these innovative sectors are however far less innovative in treated counties.
} 
is however cross-sectional and spans the whole period during which the reversal of fortune occurs. To shed some light on the the dynamics in the production structure during the transformation of the Chinese economy, we select two main outcomes, i.e., total factor productivity and the number of registered patent applications, and we estimate the treatment effect each year between 1998 and 2007.

Figure 8 reports these estimates. As apparent from Panel A, the average treated establishment is less productive in 1998, but the gap widens after 2000. These results are obtained with sectoral dummies and a set of dummies for each firm type in order to control for the slow demise of public enterprises and time variation in sectoral returns. The gap in patenting behavior between treated and control counties also widens after 2000, especially for the two most relevant categories of patents, i.e., invention and utility (reported here): the deterioration in productivity is accompanied by a stagnation in technological innovation.

Heterogeneity along treatment intensity Before analyzing heterogeneous treatment effects across establishments of the same county, we study a simpler aspect of treatment heterogeneity: the heterogeneity in treatment effects across treatment intensity (i.e., expected spillovers and co-agglomeration).

We report the analysis of treatment heterogeneity in Table 6. We focus on the following baseline outcomes, total factor productivity, the number of registered (utility) patents, and markups, and restrict the analysis to two simple measures of treatment "intensity": (i) the average I/O intensity (summing the shares of input and output linkages in the U.S. input/output matrix at the 4-digit industry level) to capture the expected extent of the production chain and (ii) a dummy equal to one if there are different products produced by local $\mathrm{MRP}(\mathrm{s})$ to capture local diversification or the co-agglomeration of different industries.

Treatment characteristics do seem to matter, at least for patenting. The average $\mathrm{I} / \mathrm{O}$ intensity aggravates the drop in patent applications (Panel A), while diversification tempers the observed drop in innovation (Panel B). Having MRPs operating in only one 4-digit industry decreases the probability to submit a patent by 2.6 percentage points; having MRPs operating in at least two distinct industries increases the probability to submit a patent by 0.8 percentage points. This finding is consistent with co-agglomeration patterns as being beneficial for technological adoption in the local economy.

These heterogenous effects suggest that the specialization and high needs for production integration of MRPs may explain the aggregate fall in economic activity. In the next section, we investigate the patterns of agglomeration of establishments 
around the $\operatorname{MRP}(\mathrm{s})$ and the characteristics of linked versus non-linked firms.

\subsection{The role of linkages between establishments}

The use of establishment-level data implies that we can identify differences in the local structure of production from the interaction of the treatment with establishment characteristics. For instance, one may compare the activity of downstream establishments in a treated county with similarly defined establishments in control counties, relative to the same difference for non-downstream establishments. A difference-in-difference specification cannot however be implemented as such, due to treatment heterogeneity, and we rationalize the use of a slightly more involved empirical strategy below.

Identification of heterogeneous effects We aim to estimate the externalities exerted by Million-Rouble plants on manufacturing establishments of the same county, through production linkages, factor market linkages, or technological linkages. For this purpose, we develop an empirical strategy to identify treatment spillovers across establishments in the presence of treatment heterogeneity. This procedure will also be useful in studying treatment heterogeneity across counties or across treatment type.

Without treatment heterogeneity, spillovers can be estimated as follows. Consider an establishment $i$ located in county $c$. We would like to estimate the statistical model $E\left[Y_{i} \mid T_{c}, S_{i}\right]$ where $Y_{i}$ is the outcome at the establishment level, $T_{c} \in\{0,1\}$ is the treatment, and $S_{i} \in\{0,1\}$ characterizes the sub-population of firms susceptible to be affected. The previous statistical model can be estimated through a simple difference-in-differences procedure, in which the instrument for treatment $T_{c}$ would be interacted with the spillover measure $S_{i}$. With treatment heterogeneity, however, the latter cannot be constructed in control counties, where $T_{c}=0$. Indeed, such a measure would crucially depend on the characteristics of the associated hypothetical Million-Rouble Plant (see Figure 9 for a childish illustration). Let $T_{c}^{\tau} \in\{0,1\}$ denote the MRP-specific treatment, equal to 1 if county $c$ hosts the MRP indexed by $\tau$, and $T_{c}=\max _{\tau}\left\{T_{c}^{\tau}\right\}$ the average treatment (i.e., hosting at least one MRP). We can define a measure of MRP-specific linkages in all counties, given the characteristics of an establishment and the characteristics of the MRP. We describe next how we attribute hypothetical MRPs to control counties.

We stratify control counties by their suitability to host Million-Rouble Plants. We define strata of counties based on deciles of the propensity score $P\left(\mathbf{H}_{c}\right)$, as produced by the propensity-score matching procedure described in Section 2 (relying 
on observable characteristics $\mathbf{H}_{c}$ ). In each stratum, there is a subset of treated counties and their associated MRP types. We assume that the probability to host any such MRP type $\tau$ is the same for all control counties in the stratum. Under this assumption, we can simulate Monte-Carlo draws of the distribution of MRP types within treated counties in control counties of the same stratum. ${ }^{31}$ For each simulation, we calculate hypothetical links $S_{i}$, using the observed characteristics of establishments in these control counties.

For each Monte-Carlo draw, we estimate the following IV specification in differencein-differences on the sample of all establishments surveyed in year $t$ and located in suitable counties, excluding the MRPs themselves:

$$
Y_{i s c t}=\beta_{0}+\beta_{1} T_{c}+\beta_{2} T_{c} \times S_{s c t}+\beta_{3} S_{s c t}+\mathbf{X}_{c} \beta_{\mathbf{x}}+\mu_{s}+\nu_{t}+\xi_{s t}+\varepsilon_{i s c t}
$$

where $\left(T_{c}, T_{c} \times S_{s c t}\right)$ is instrumented by $\left(V_{c}, V_{c} \times S_{s c t}\right)$, and $Y_{i s c t}$ is measured at the establishment level. The identification relies on the difference between linked and non-linked establishments in treated and control counties, using product market dummies $\mu_{s}$ to clean for omitted variation across sectors, as well as year $\left(\nu_{t}\right)$ and sector $\times$ year fixed effects $\left(\xi_{s t}\right)$. A similar specification can be estimated replacing $S_{\text {sct }}$ by treatment characteristics.

The identification crucially hinges on a weaker version of the Conditional Independence Assumption. The allocation of a certain MRP of type $\tau$ needs to be independent of unobserved county characteristics that may directly affect outcome $Y$, conditional on the propensity score $\tilde{P}\left(\mathbf{H}_{c}\right)$.

Definition of linkages between establishments In order to capture production links between establishments, we first construct a measure of vertical linkages. We define a measure of downstream linkages, from the MRP down to the establishment, as follows:

$$
V^{d}=\left(\sum_{g, G} \alpha_{g} \alpha_{G} \beta_{g, G}\right) /\left(\sum_{g, G} \alpha_{g} \alpha_{G}\right)
$$

where $\alpha_{g}$ and $\alpha_{G}$ are the shares of good $g$ and $G$ in total revenues of the establishment and the MRP, respectively, and $\beta_{g, G}$ is the share of input expenditures spent on $G$ in order to produce good $g$. We proxy $\beta_{g, G}$ using the input/output matrix in the United States in 2000, and a bridge between standardized product codes (HS6) and Chinese codes. As we cannot allocate revenue shares to the different goods produced by an establishment, we use a simple average of product-specific measures $\beta_{g, G}$ across

\footnotetext{
${ }^{31}$ We simulate these draws as follows. For each control county, we draw one treated county from the same stratum and attribute to the control county the $\operatorname{MRP}(\mathrm{s})$ present in the drawn county.
} 
goods and define a dummy, Downstream, equal to 1 if $V^{d}$ is higher than the 95\%quantile across all establishments of the sample. We define a dummy, Upstream, in a similar way to characterize upstream establishments.

The ideal measure of horizontal linkages would weight the production of products $g$ and $G$ by an indicator of the degree of substitutability between goods $g$ and $G$. In practice, however, we do not have (yet) consistent measures of substitutability between goods, and it is hard to allocate revenue shares to different goods produced by an establishment. Our empirical measure $S$ will thus be an indicator, Same product, equal to 1 if the establishment produces at least one good (4-digit level) also produced by a local MRP.

We define a measure of competition on factor markets based on revealed factor intensities as predicted by trade patterns in 2000 (see Shirotori et al., 2010, for the construction of revealed factor intensities at the HS6-level). Letting $F I_{g}$ denote the revealed factor intensity for factor $F$ (human capital, physical capital, or land) and good $g$, we define a dummy, More F-intensive, equal to one if the average $F I_{g}$ over all the goods produced by an establishment is higher than the average $F I_{G}$ over all the goods produced by local MRPs. The rationale is that MRPs may have a higher bargaining power on factor markets, e.g., because they face lower search frictions; their privileged access to resources may particularly affect those establishments whose needs for this production factor are more pressing. Finally, we define a measure of technological closeness computed at the industry level, i.e., a matrix of technological closeness measures, using U.S. data (Bloom et al., 2013) and a bridge between SIC codes and Chinese industry codes. We define a dummy, Tech. clos., equal to 1 if technological closeness is higher than the 95\%-quantile across all establishments.

Treatment effect on the structure of linkages Table 7 (Panel A) reports the relative presence of establishments operating downstream, upstream, and in the same product market as the local $\mathrm{MRP}(\mathrm{s})$. In column 1, we report the result of a specification in which the measure of downstream linkages at the establishment level is regressed on the treatment, instrumented by vulnerability to air strikes. One alternative specification would be to estimate Equation (1) with an aggregate measure of linkages as the dependent variable in order to understand the formation of the network around the $\mathrm{MRP}(\mathrm{s})$, e.g., an excess of downstream establishments. Both specifications give similar results and we only report the estimates of Equation (2). We find that the treatment increases the probability for an establishment to operate downstream of the MRP by about 5 percentage points (this probability is about $2 \%$ 
in control counties). Columns 2 and 3 of Table 7 report the results of Specification (2) with upstream linkages and horizontal linkages as dependent variables. The treatment effect on the probability for an establishment to operate upstream of the MRP is non-negligible, even though MRPs tend to operate early in the production chain. The treatment does also affect the probability to operate in the same product market, which increases by 5 percentage points - an effect that we can attribute to economies of scale (Ciccone, 2002). Overall, the production chain of the MRP(s) would represent about $5 \%$ of all establishments in the average control county against $20 \%$ in the average treated county

As the estimation procedure relies on multiple draws, we report here the average effect and the average standard error over 100 simulations. Correct inference would require to bootstrap standard errors. Note that we exclude the MRPs from the estimation, that we control for year and 4-digit product fixed effects, and that standard errors are clustered at the level of 4-degree $\times 4$-degree cells.

Table 7 (Panel B) reports the relative presence of establishments with more acute demand for human capital (column 1), physical capital (column 2), and land (column 3) than the local $\mathrm{MRP}(\mathrm{s})$. The differences between treated and control counties are minimal - a few percentage points, to be compared with averages at around 50 percentage points. These findings provide little support for the existence of spillovers in factor markets. Finally, Table 7 (Panel C) reports the relative presence of establishments with a technology closeness measure above the 95\%-quantile. The difference between treated and control counties is small, albeit imprecisely measured, possibly reflecting treatment heterogeneity.

Treatment effect for linked and non-linked establishments The previous table has identified the change in the structure of production induced by the presence of the $\operatorname{MRP}(\mathrm{s})$ : there are many more establishments operating along the production chain. Spillovers seem to be non-negligible along the production chain, which is consistent with economies of scale within the same product market (Kim, 1995; Ciccone, 2002). We now characterize the establishments along the production chain, by interacting treatment with production linkages. We select the following outcomes for this exercise: total factor productivity, the number of registered (utility) patents, and markups.

The gap with control counties in patenting intensity is surprisingly more pronounced for downstream/upstream establishments (see column 2, Panel A of Table 8). The (negative) treatment effect on utility patents is five times larger for these establishments than for other establishments. This effect illustrates that linked 
establishments usually operate in very innovative industries; they do not, however, innovate in treated counties. This result sharply contrasts with our finding on productivity (and markups, to a lesser extent - see columns 1 and 3 of Table 8): establishments along the production chain of $\operatorname{MRP}(\mathrm{s})$ are slightly more productive than their counterparts in control counties. The same general patterns can be observed for establishments in the same product market (Panel B) ${ }^{32}$

How can we reconcile these two results (i. low innovation and ii. high productivity and high markups)? One interpretation of these findings is that establishments along the production chain of $\operatorname{MRP}(\mathrm{s})$ enjoy a technological rent from their proximity with a highly productive and innovative factory. These establishments extract part of the final value added when operating at one point of the production chain, whether upstream or downstream, and they do not need to incur innovation efforts. ${ }^{33}$ This technological rent provides incentives for establishments and entrants to tie their production to the MRP technology, thereby explaining the very large cluster of specialized production units around the MRP.

With a highly concentrated structure of production and non-innovative nucleus of firms, treated counties do not benefit much from the externalities in local technological progress, whether it be within or across industries (Glaeser et al., 1992; Beaudry and Schiffauerova, 2009). One question remains: why are there so few establishments outside the production chain of MRPs? We capture this possible channel in the next section, in which we look at potential entrants and indirectly analyze the decision to set up a production establishment across sectors.

\subsection{Entrepreneurial supply}

In the ideal setting, we would like to observe the universe of potential entrants in different counties in order to distinguish the production of entrepreneurs (human capital) from the realization of entrepreneurial activities. We study this question in two (imperfect) steps. In a first step, we study the relocation of ideas through the creation of firms by emigrants from treated and control counties. In a second step, we study the production of ideas through the analysis of aspirations and values in treated and control counties.

\footnotetext{
${ }^{32}$ Establishment characteristics do differ across treatment and along the production chain. Compositional effects cannot however explain the patenting behavior of those establishments: SOEs are more innovative than other establishments in these counties. See Appendix E for a proper investigation of compositional effects.

${ }^{33}$ The effect of a large, innovative establishment on the markup set by intermediaries could be ambiguous. On the one hand, the production chain probably generates high rents, which should influence the markup set by intermediaries. On the other hand, the large establishment may benefit from a more advantageous bargaining position when negotiating with intermediaries or suppliers.
} 
An entrepreneurial drain? We implement Specification (1), regressing average emigrant characteristic $Y_{c}$ at the county level on $T_{c}$, instrumented by $V_{c}$. The data come from the 2005 Mini-Census, which contains information on the county of origin (defined as the place of registration), migration status, and individual characteristics (level of education, employment status, income). The dependent variable $Y_{c}$ is the share of emigrants from county $c$ with characteristic $Y$ in 2005, normalized by the share of the population of $c$ with characteristic $Y$ in the 2000 population census. ${ }^{34}$ All dependent variables are standardized.

Table 9 investigates the treatment effect on the profile of emigrants, focusing on characteristics of (successful) entrepreneurs: educational attainment, occupation, employment type, and income. Column 1 shows that emigrants from treated counties are more likely to be positively selected in terms of education than emigrants from control counties: the share of emigrants with a tertiary degree (normalized by the share of the population with a tertiary degree) is $77 \%$ of a standard deviation higher in treated than control counties. In column 2, we can see that migrants from treated counties are more likely to hold a manager position at destination, although the coefficient is not statistically significant. Columns 3 and 4 show that they are also much more likely to be self-employed workers or employers in their counties of residence. Finally, column 5 shows that emigrants from treated counties are more likely to earn incomes in the top $20 \%$ of the income distribution than emigrants from control counties.

These results suggest that the treatment generates a local environment that is not conducive to firm creation outside the production chain of MRPs. Even when potential entrepreneurs are produced, they prefer to export their skills to and set up firms in other counties.

Entrepreneurial spirit The results in Table 9 show that distortions in the local supply of entrepreneurs. Such distortions may in turn discourage the production of entrepreneurs, or entrepreneurial spirit. ${ }^{35}$

We investigate the effect of the MRP on the values and aspirations of the local population using the China Family Panel Survey (CFPS).

In Table 10, we extend Specification (1) at the individual level and regress mea-

\footnotetext{
${ }^{34}$ The place of residence or destination is not recorded at the same level of precision in the Mini-Census. This prevents us from observing directly the characteristics of immigrants and nonmigrants in 2005.

${ }^{35}$ Entrepreneurial spirit could also result from a composition effect-large industrial investments attract factory workers, not entrepreneurs - or a treatment effect - people born near large industrial investments can more easily access factory jobs. These two mechanisms were first hypothesized by Chinitz (1961) to explain the demise of the Rust Belt.
} 
sures of values or aspirations on the treatment $T_{c}$, instrumented by $V_{c}$. In all individual-level specifications, we clean for respondent and household characteristics. $^{36}$ We focus the analysis on two modules (included in CFPS in 2014). The aspiration module applied to households with children aged 0-15, and answers were collected from their parents. The values module applied to children aged $12-15 .{ }^{37}$

In Panel A of Table 10, we analyze aspirations, focusing on education and job prestige. The population in treated counties is significantly more likely to aspire to tertiary education: treated respondents are 8 percentage points more likely to aspire to a master's degree (for themselves or for their children), compared to an average response of $6 \%$ in the control group. Respondents in control counties are also more likely to report that no schooling is necessary, but the effect is small (column 2). In column 3, we show that job prestige is significantly more likely to be emphasized in households living near a MRP.

We next investigate the role of the treatment in values. We use the following survey questions from CFPS:

1 Do you agree that the most important factor that determines one's success is how hard she works?

$(1=$ do not agree at all; $5=$ completely agree $)$

2 Do you agree that for the economy to thrive, one needs to enlarge income inequality in the population? $(1=$ do not agree at all; $5=$ completely agree $)$

3 How important is talent to a child's future achievement? $(1=$ not important at all; $5=$ extremely important $)$

In Panel A of Table 10, we regress these values variables on the treatment indicator, instrumented by vulnerability to enemy airstrikes. We find that individuals in treated counties are less likely to think that hard work will be rewarded in today's society, that inequality is necessary, and that talent is important for success. ${ }^{38}$

These results are consistent with lower individualism and a decline in entrepreneurship. They may reflect (i) a composition effect, as manufacturing industries predominantly attract factory workers who may be negatively selected in terms of entrepreneurial values, and (ii) a treatment effect on the local culture, potentially

\footnotetext{
${ }^{36} \mathrm{We}$ control for the respondent's age in 2014 and gender, and for the household's level of education, mean income, and urban status. We further control for proxy response.

${ }^{37}$ Only a subset of the CFPS households live in treated or matched control counties. Sample size ranges from 420 for the values module to 1,838 in the aspirations module, which corresponds to about 30 counties.

${ }^{38}$ This last question was asked to all children aged 0-15 (or their proxies).
} 
mediated by distortionary effects on entrepreneurs' location choices. The results shown in Table 10 are compatible with both interpretations.

\section{Conclusion}

Industrialization and the concentration of large industrial clusters may have longlasting effects on local economies. This paper provides evidence of a rise-and-fall pattern in the long run, even without aggregate manufacturing decline and despite the success of the initial investments at the origin of the clusters, and identifies the externalities supporting this effect using granular data on production units.

The paper relies on a unique experiment (the "156" program), in which large factories were (quasi-)randomly allocated across suitable counties in China, and it follows the evolution of these locations along the structural transformation of the economy. While the "156" program was effective in spurring transformation from agriculture to manufacturing and in raising living standards, this head start failed to generate agglomeration economies in the later period. Low mobility costs and the liberalization of the economy would have been expected to widen the gap between treated places and the rest of the economy. We find the opposite.

The reforms reversed the fate of the places that received investments under the "156" program. A large share of the GDP gains from the command-economy period vanished in the course of the opening-up era, bringing treated and control counties closer over time. This reversal of fortune occurred even though the Million-Rouble plants created under the program were still about four times as productive as similar firms in the 1990s and 2000s. However, treated areas did not merely revert to the path followed by other places in the absence of the "156" program; they suffer from a double curse. The first curse is that they are now far less innovative than control counties. The structure of production is far too concentrated along the production chain of the 156 Million-Rouble Plants, and technological spillovers appear to be minimal. The second curse relates to culture: their populations are now less individualistic and pro-effort, and their environment appears generally less conducive to entrepreneurship. Potential entrepreneurs born in treated counties are more likely to leave and set up firms elsewhere. Early industrialization has a persistent, albeit now adverse, influence on local economies. 


\section{References}

Aghion, Philippe, Jing Cai, Mathias Dewatripont, Luosha Du, Ann Harrison, and Patrick Legros, "Industrial policy and competition," American Economic Journal: Macroeconomics, 2015, 7 (4), 1-32.

Aitken, Brian J and Ann E Harrison, "Do domestic firms benefit from direct foreign investment? Evidence from Venezuela," American Economic Review, 1999, $89(3), 605-618$.

Alder, Simon, Lin Shao, and Fabrizio Zilibotti, "Economic reforms and industrial policy in a panel of Chinese cities," Journal of Economic Growth, 2016, 21 (4), 305-349.

Ansteel Group Corporation, Ansteel Group Corporation Sustainability Report 2016, Ansteel, 2016.

Beaudry, Catherine and Andrea Schiffauerova, "Who's right, Marshall or Jacobs? The localization versus urbanization debate," Research Policy, 2009, 38 (2), 318-337.

Bergin, Bob, "The Growth of China's Air Defenses: Responding to Covert Overflights, 1949-1974," Studies in Intelligence, June 2013, 57 (2), 19-28.

Bloom, Nicholas, Mark Schankerman, and John Van Reenen, "Identifying technology spillovers and product market rivalry," Econometrica, 2013, 81 (4), $1347-1393$.

Bo, Yibo, Review of Several Major Decisions and Events [Ruogan Zhongda Juece yu Shijian de Huigu], Beijing: The Chinese Communist Party School Press [Zhonggong Zhongyang Dangxiao Chuban She], 1991.

Brandt, Loren, Gueorgui Kambourov, and Kjetil Storesletten, "Firm Entry and Regional Growth Disparities: the Effect of SOEs in China," Technical Report May 2016.

_, Johannes Van Biesebroeck, and Yifan Zhang, "Challenges of working with the Chinese NBS firm-level data," China Economic Review, 2014, 30 (C), 339-352.

_ , Trevor Tombe, and Xiaodong Zhu, "Factor market distortions across time, space and sectors in China," Review of Economic Dynamics, 2013, 16 (1), 39-58.

Buera, Francisco J. and Yongseok Shin, "Financial Frictions and the Persistence of History: A Quantitative Exploration," Journal of Political Economy, 2013, 121 (2), 221-272.

Busso, Matias, Jesse Gregory, and Patrick Kline, "Assessing the Incidence and Efficiency of a Prominent Place Based Policy," American Economic Review, 2013, 103 (2), 897-947. 
Carlino, Gerald and William R. Kerr, "Chapter 6 - Agglomeration and Innovation," in Gilles Duranton, J. Vernon Henderson, and William C. Strange, eds., Handbook of Regional and Urban Economics, Vol. 5 of Handbook of Regional and Urban Economics, Elsevier, 2015, pp. 349 - 404.

Chen, Ying, J. Vernon Henderson, and Wei Cai, "Political favoritism in China's capital market and its effect on city sizes," Journal of Urban Economics, 2017, 98 (C), 69-87.

Chinese Academy of Social Sciences and State Archives Administration, Selected Economic Archives of the People's Republic of China, 1953-195\%: Volume on Fixed Assets and Construction [in Chinese], Beijing: China Price Press, 1998.

Chinitz, Benjamin, "Contrasts in Agglomeration: New York and Pittsburgh," The American Economic Review, 1961, 51 (2), 279-289.

Ciccone, Antonio, "Input chains and industrialization," The Review of Economic Studies, 2002, 69 (3), 565-587.

Crescenzi, Riccardo, Andrés Rodríguez-Pose, and Michael Storper, "The territorial dynamics of innovation in China and India," Journal of Economic Geography, 2012, 12 (5), 1055-1085.

De Loecker, Jan and Frederic Warzynski, "Markups and firm-level export status," American Economic Review, 2012, 102 (6), 2437-71.

Desmet, Klaus and Esteban Rossi-Hansberg, "Spatial development," American Economic Review, 2014, 104 (4), 1211-43.

Dong, Zhikai, "On the Establishment of the "156 Program" [in Chinese]," Researches in Chinese Economic History, 1999, 4, 93-107.

- and Jiang Wu, Industry Cornerstone of New China [in Chinese], Guangzhou: Guangdong Economy Publishing House, 2004.

Duranton, Gilles and Diego Puga, "Nursery cities: Urban diversity, process innovation, and the life cycle of products," American Economic Review, 2001, 91 (5), 1454-1477.

_ and _, "Chapter 5 - The Growth of Cities," in Philippe Aghion and Steven N. Durlauf, eds., Handbook of Economic Growth, Vol. 2 of Handbook of Economic Growth, Elsevier, 2014, pp. $781-853$.

Eckstein, Alexander, China's Economic Revolution, Cambridge: Cambridge University Press, 1977.

Faggio, Giulia, Olmo Silva, and William C. Strange, "Heterogeneous agglomeration," Review of Economics and Statistics, 2017, 99 (1), 80-94. 
Falck, Oliver, Christina Guenther, Stephan Heblich, and William R. Kerr, "From Russia with love: the impact of relocated firms on incumbent survival," Journal of Economic Geography, May 2013, 13 (3), 419-449.

Fan, Jingting and Ben Zou, "Industrialization from Scratch: The Third Front and Local Economic Development in China's Hinterland," 2015.

_ and _ , "Industrialization from Scratch: The "Construction of Third Front" and Local Economic Development in China's Hinterland," Technical Report, Working Paper 2019.

Fang, Lily, Josh Lerner, Chaopeng Wu, and Qi Zhang, "Corruption, Government Subsidies, and Innovation: Evidence from China," Working Paper 25098, National Bureau of Economic Research September 2018.

Fogel, Robert, Railroads and American economic growth: Essays in econometric history, Baltimore, MD: Johns Hopkins University Press, 1964.

Franck, Raphaël and Oded Galor, "Industrial Development and Long-Run Prosperity," NBER Working Papers 23701, National Bureau of Economic Research, Inc August 2017.

Gerschenkron, Alexander, Economic Backwardness in Historical Perspective: A Book of Essays, Cambridge, MA: Belknap Press of Harvard University Press, 1962.

Glaeser, Edward L., "Reinventing Boston: 1630-2003," Journal of Economic Geography, 2005, 5 (2), 119-153.

- and Janet E. Kohlhase, "Cities, regions and the decline of transport costs," Papers in Regional Science, 2004, 83 (1), 197-228.

Glaeser, Edward L, Hedi D Kallal, Jose A Scheinkman, and Andrei Shleifer, "Growth in cities," Journal of Political Economy, 1992, 100 (6), 11261152 .

Glaeser, Edward L., Sari Pekkala Kerr, and William R. Kerr, "Entrepreneurship and urban growth: An empirical assessment with historical mines," Review of Economics and Statistics, 2015, 97 (2), 498-520.

Goncharenko, Sergei, Beijing and Moscow: From Allies to Enemies [in Chinese], Guangxi Normal University Press, 2002.

Greenstone, Michael, Richard Hornbeck, and Enrico Moretti, "Identifying Agglomeration Spillovers: Evidence from Winners and Losers of Large Plant Openings," Journal of Political Economy, 2010, 118 (3), 536-598.

Harrison, Ann, Marshall Meyer, Peichun Wang, Linda Zhao, and Minyuan Zhao, "Can a Tiger Change Its Stripes? Reform of Chinese StateOwned Enterprises in the Penumbra of the State," Technical Report, National Bureau of Economic Research 2019. 
Haskel, Jonathan E, Sonia C Pereira, and Matthew J Slaughter, "Does inward foreign direct investment boost the productivity of domestic firms?," The Review of Economics and Statistics, 2007, 89 (3), 482-496.

He, Yimin and Mingchang Zhou, "The 156 Program and the Development of Industrial Cities in New China (1949-1957) [in Chinese]," Contemporary China History Studies, 2007, 14 (2), 70-77.

He, Zi-Lin, Tony W Tong, Yuchen Zhang, and Wenlong He, "A database linking Chinese patents to China's census firms," Scientific data, 2018, 5, 180042.

Head, Keith, John Ries, and Deborah Swenson, "Agglomeration benefits and location choice: Evidence from Japanese manufacturing investments in the United States," Journal of International Economics, 1995, 38 (3-4), 223-247.

Henderson, J Vernon, Zmarak Shalizi, and Anthony J Venables, "Geography and development," Journal of Economic Geography, 2001, 1 (1), 81-105.

Hsieh, Chang-Tai and Peter J. Klenow, "Misallocation and Manufacturing TFP in China and India," The Quarterly Journal of Economics, November 2009, 124 (4), 1403-1448.

- and Zheng Song, "Grasp the Large, Let Go of the Small: The Transformation of the State Sector in China," NBER Working Papers 21006, National Bureau of Economic Research, Inc March 2015.

Imbert, Clement, Marlon Seror, Yifan Zhang, and Yanos Zylberberg, "Migrants and Firms: Evidence from China," Technical Report December 2018.

Javorcik, Beata Smarzynska, "Does foreign direct investment increase the productivity of domestic firms? In search of spillovers through backward linkages," American Economic Review, 2004, 94 (3), 605-627.

Kim, Sukkoo, "Expansion of markets and the geographic distribution of economic activities: the trends in US regional manufacturing structure, 1860-1987," The Quarterly Journal of Economics, 1995, 110 (4), 881-908.

Kline, Patrick and Enrico Moretti, "Local Economic Development, Agglomeration Economies, and the Big Push: 100 Years of Evidence from the Tennessee Valley Authority," The Quarterly Journal of Economics, 2014, 129 (1), 275-331.

Konings, Jozef, "The effects of foreign direct investment on domestic firms," Economics of Transition, 2001, 9 (3), 619-633.

Lardy, Nicholas R., Economic Recovery and the First Five-Year Plan, Cambridge University Press, 1987.

Li, Fuchun, Achievements of the First Three Years of the Five-Year Plan and Missions for the Next Two Years: Report at the National Assembly of Young Activists for the Construction of Socialism [in Chinese], Beijing: China Youth Publishing, September 1955. 
-, Report on the First Five-Year Plan for the Development of the National Economy-At the Second Meeting of the First National People's Congress on July 5-6, 1955 [in Chinese], Beijing: National Committee of the Chinese People's Political Consultative Conference, July 1955.

Lüthi, Lorenz M., The Sino-Soviet split: Cold War in the communist world, Princeton University Press, 2010.

Mayneris, Florian, Sandra Poncet, and Tao Zhang, "Improving or Disappearing: Firm-Level Adjustments to Minimum Wages in China," Journal of Development Economics, 2018, 135, 20-42.

Naughton, Barry, The Chinese Economy: Transformation and Growth, Cambridge, MA: MIT Press, 2007.

Neumark, David and Helen D. Simpson, "Place-Based Policies," in Gilles Duranton, J.V. Henderson, and William Strange, eds., The Handbook of Regional and Urban Economics, Elsevier/Academic Press, 2015.

Ngai, L. Rachel and Christopher A. Pissarides, "Structural Change in a Multisector Model of Growth," American Economic Review, March 2007, 97 (1), 429-443.

Pierce, Justin R and Peter K Schott, "The surprisingly swift decline of US manufacturing employment," American Economic Review, 2016, 106 (7), 163262.

Polèse, Mario, The Wealth and Poverty of Regions: Why Cities Matter, The University of Chicago Press, 2009.

Rawski, Thomas, Economic Growth and Employment in China, Oxford: Oxford University Press, 1979.

Rong, Xinchun, "On the Development and Changes of the Shipping Business in New China (1949-2010) [in Chinese]," Researches in Chinese Economic History, 2012, 2, 127-137.

Rosenstein-Rodan, Paul N., "Problems of Industrialisation of Eastern and South-Eastern Europe," The Economic Journal, 1943, 53 (210/211), 202-211.

Schweiger, Helena, Alexander Stepanov, and Paolo Zacchia, "The longrun effects of R\&D place-based policies: evidence from Russian science cities," Technical Report, European Bank for Reconstruction and Development June 2018.

Selden, Mark and Patti Eggleston, The People's Republic of China. A Documentary History of Revolutionary China, New York: Monthly Review Press, 1979.

Shi, Wenjie, "A Study of the "156 Program" and its Influence on the Early Modernization of New China [in Chinese]," Financial Information, 2013, 1, 42-45. 
Shi, Xiangyu, Tianyang Xi, Xiaobo Zhang, and Yifan Zhang, "Moving "Umbrella": Bureaucratic Transfers, Collusion, and Rent-seeking in China," Technical Report March 2018.

Shirotori, Miho, Bolormaa Tumurchudur, and Olivier Cadot, Revealed factor intensity indices at the product level, Vol. 44, UN, 2010.

Song, Zheng, Kjetil Storesletten, and Fabrizio Zilibotti, "Growing Like China," American Economic Review, 2011, 101 (1), 196-233.

Tang, Yanyan, "An Analysis of the Advantage of Backwardness Based on the Construction of the "156" Program [in Chinese]," Theory Monthly, 2009, 20.

Tombe, Trevor and Xiaodong Zhu, "Trade, Migration and Productivity: A Quantitative Analysis of China," June 2015.

von Ehrlich, Maximilian and Tobias Seidel, "The Persistent Effects of PlaceBased Policy: Evidence from the West-German Zonenrandgebiet," American Economic Journal: Economic Policy, 2018, 10 (4), 344-74.

Walder, Andrew G, "Rebellion and repression in China, 1966-1971," Social Science History, 2014, 38 (3-4), 513-539.

Wang, Jin, "The economic impact of special economic zones: Evidence from Chinese municipalities," Journal of development economics, 2013, 101, 133-147.

Wang, Qi, "An Analysis of the "156 Program" and Sino-Soviet Relations in the 1950s [in Chinese]," Contemporary China History Studies, 2003, 10, 110-116.

Xia, Fei, "The Third Front Movement: One of Mao Zedong's Major Strategic Decisions [in Chinese]," Over the Party History, 2008, 1, 45-48.

Xiao, Xiang, Study of the Role of Government in China's Industrialization [in Chinese], Economic Science Press, 2014.

Zhang, Jiuchun, "A Study of the "156 Program" of Industrial Construction in the 1950s [in Chinese]," Journal of Engineering Studies, 2009, 1, 213-222.

Zhang, Shuguang, Economic Cold War: America's Embargo against China and the Sino-Soviet Alliance, 1949-1963, Stanford, CA: Stanford University Press, 2001.

Zheng, Siqi, Weizeng Sun, Jianfeng Wu, and Matthew E. Kahn, "The birth of edge cities in China: Measuring the effects of industrial parks policy," Journal of Urban Economics, July 2009, 100, 80-103.

_ , _ , , and _ , "The birth of edge cities in China: Measuring the effects of industrial parks policy," Journal of Urban Economics, 2017, 100, 80-103. 


\section{A Figures and tables}

Figure 1. Transport network in 1948 and access to natural resources.

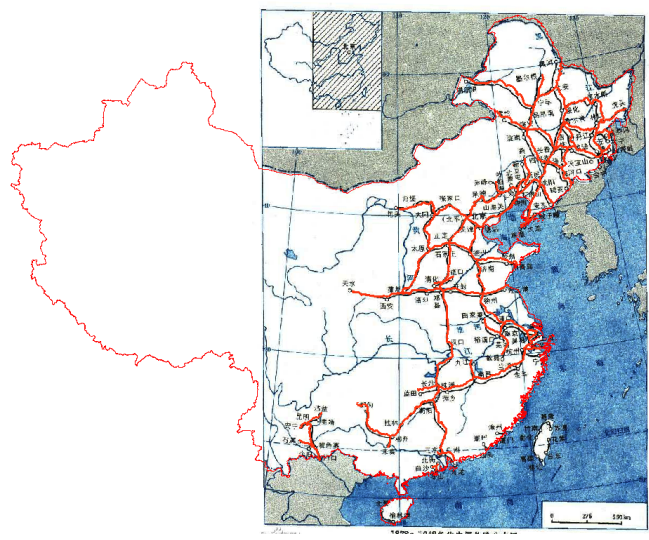

(a) Transport network in 1948 .

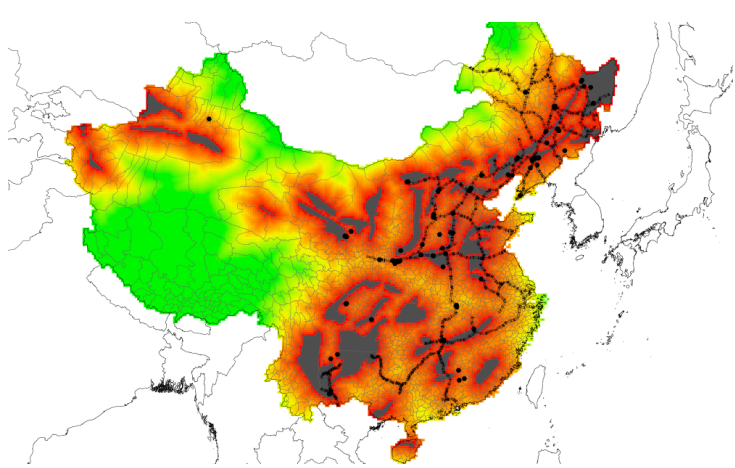

(b) Access to natural resources (coal).

Sources: The left panel is a Railroad Map of China (1948, Joint Intelligence Committee). Black lines are from the original source; red lines are inferred poly-lines using current geocoded railroad lines and cities. The right panel represents the minimum travel time to coal-bearing areas using the railroad and road networks (red: low travel time, green: high travel time). Railroads and roads are geo-located from 1948 and 1962 maps, respectively. Factory locations are indicated with black dots, coal-bearing zones are highlighted with gray areas.

Figure 2. Matching and balance of covariates.

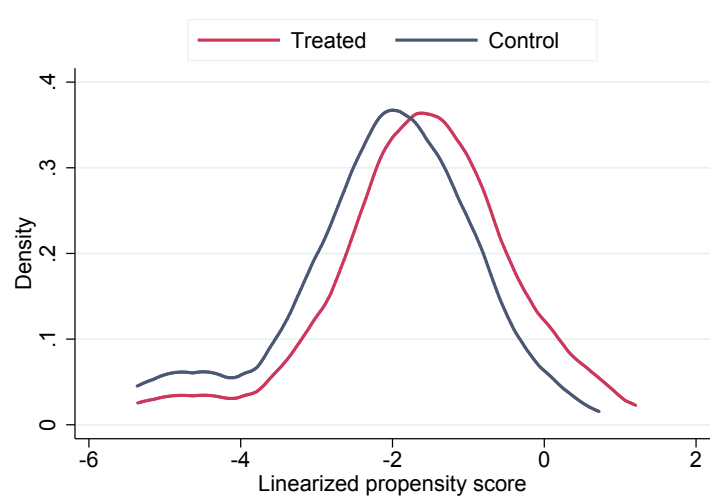

(a) Common support (propensity score).

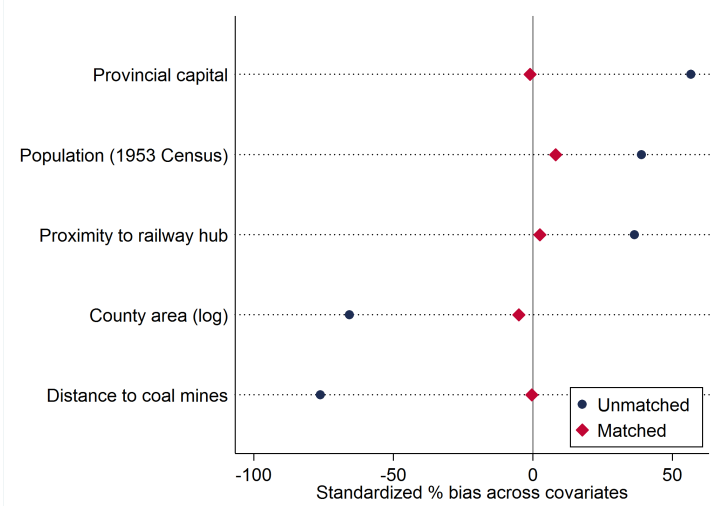

(b) Balance of covariates.

Sources: The left panel displays the distributions of the propensity score within the set of treated counties (red) and control counties (blue). The right panel shows the bias in covariates in treated counties within the whole sample and the matched sample. 
Figure 3. Treated counties and the group of control counties.

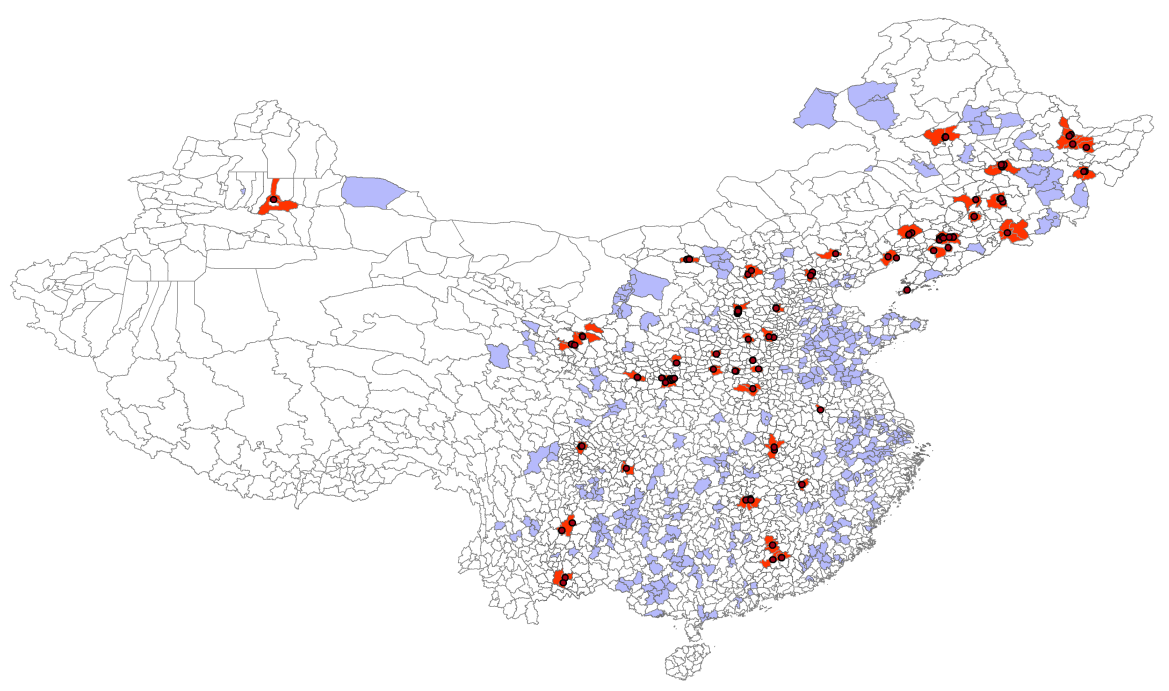

Notes: This map show counties that host at least one "156"-program factory (red) and the control group of counties (blue). The control group is selected through the matching procedure described in Section 2. 
Figure 4. Vulnerability map.

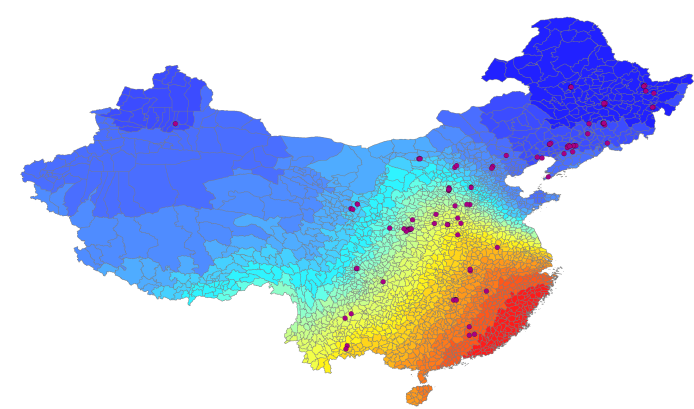

(a) Pre-1960 split

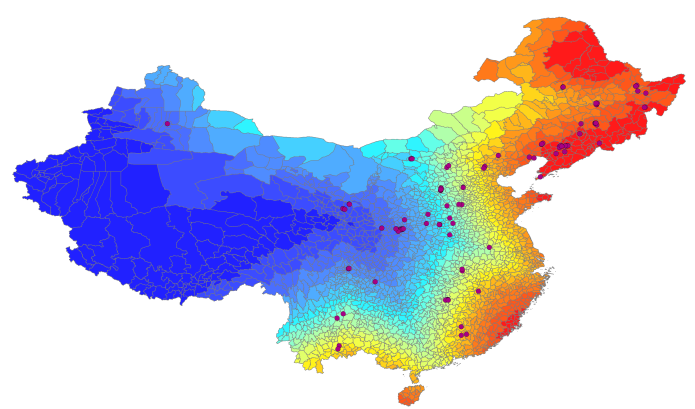

(b) Post-1960 split

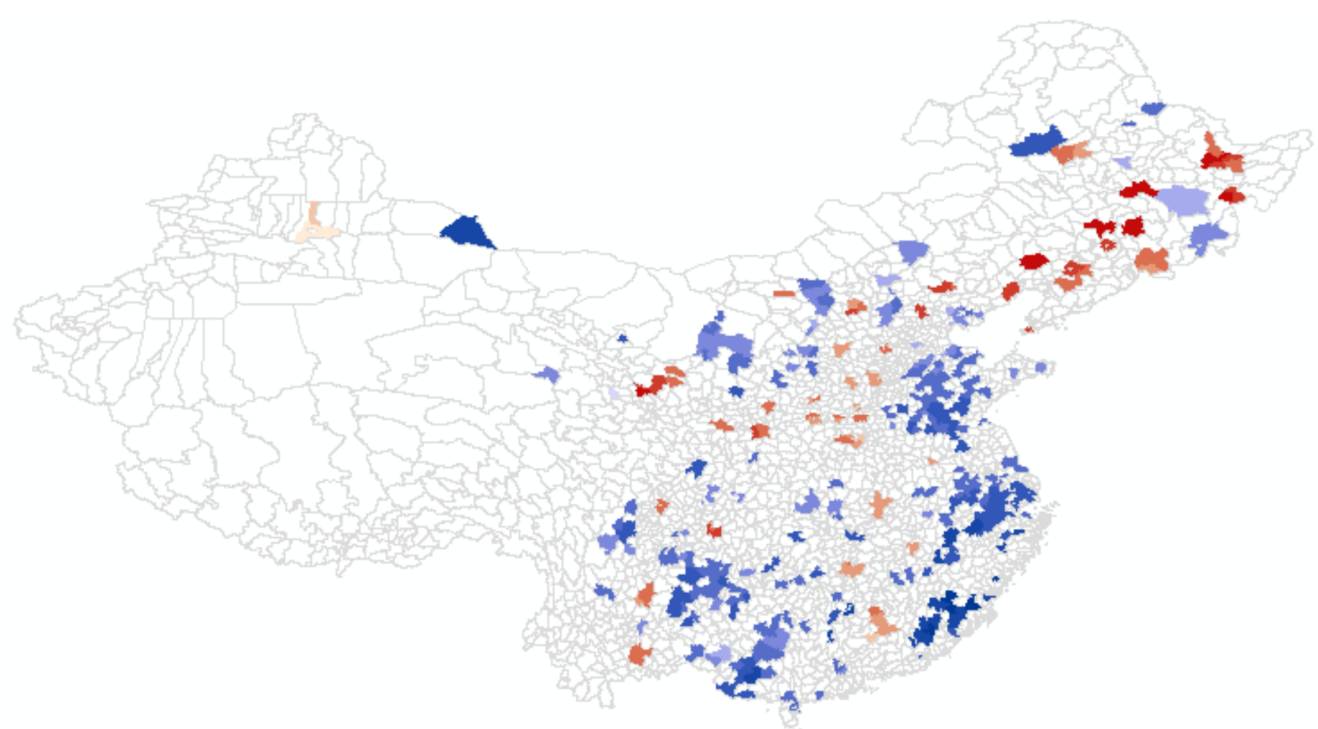

(c) Exogenous variation

Notes: This map shows the variation used for identification. Panels (a) and (b), resp., represent the penalized travel time from enemy airfields (red: low travel time, blue: high travel time) before 1960 and after 1960 (1964). The color gradient in Panels (a) and (b) corresponds to deciles of the distribution of penalized travel time. Panel (c) displays the residuals from the regression of the penalized travel time shown in Panel (a) on the first-stage controls (see Table 1, column 3), for the treated (red) and control counties (blue). Colors in Panel (c) change by steps of one standard deviation; a darker color corresponds to a higher, i.e., more positive, residual for treated counties, and to lower, i.e., more negative, residuals for control counties. 
Figure 5. Relationship between exogenous variation and distance to the coast.

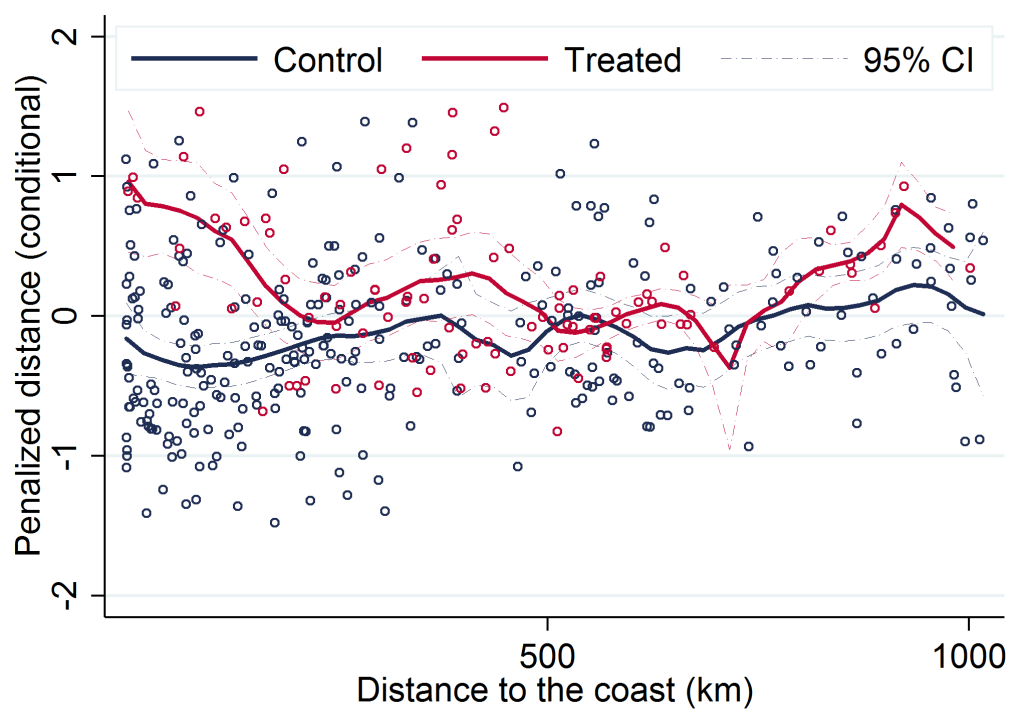

Notes: This graph plots the residuals from the regression of the penalized travel time shown in Panel (a) on the firststage controls (see Table 1, column 3), for the treated (red) and control counties (blue). The fitted lines correspond to locally weighted regressions, in red for treated and in blue for control counties; $95 \%$ confidence intervals are materialized by dashed lines of the same colors.

Figure 6. Vulnerability density within treated and control counties.

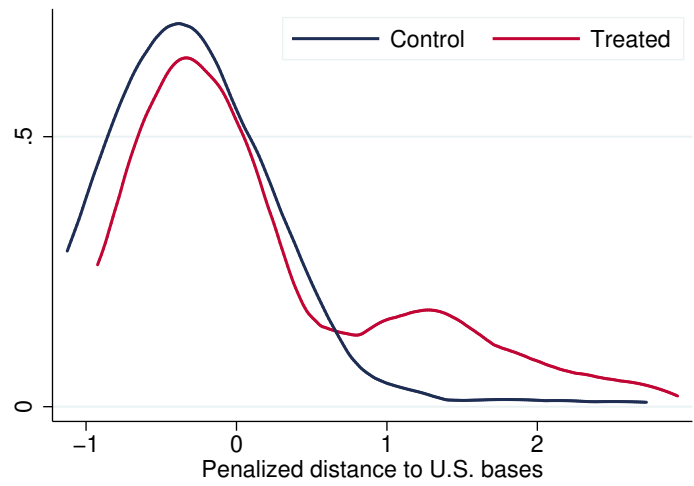

(a) Unconditional

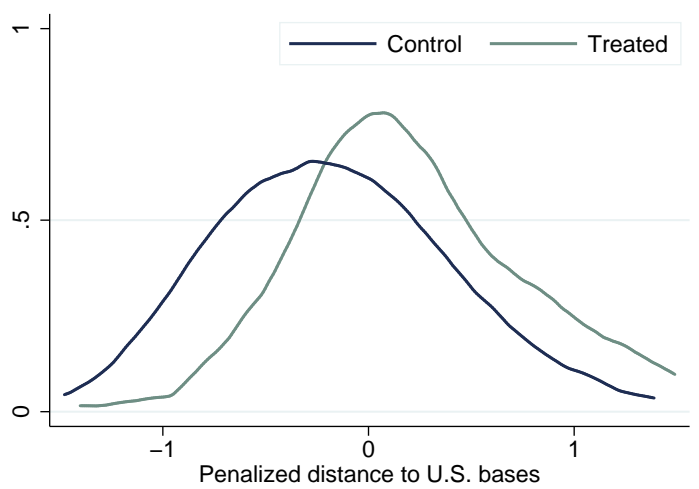

(b) Conditional

Notes: This Figure displays the density of the unconditional and conditional vulnerability measure. Penalized distance to U.S. bases is the standardized distance to the main military U.S. or Taiwanese airfields penalized by the proximity to U.S.S.R. and North Korean airfields. Treatment is defined as a dummy equal to 1 if a county centroid lies within $20 \mathrm{~km}$ of a factory and 0 otherwise. The control group is selected through the matching procedure described in Section 2, and the extended controls are those of Table 1, column 3. 
Figure 7. Illustration of the treatment effect over time (employment share in industry and share of urban area)).

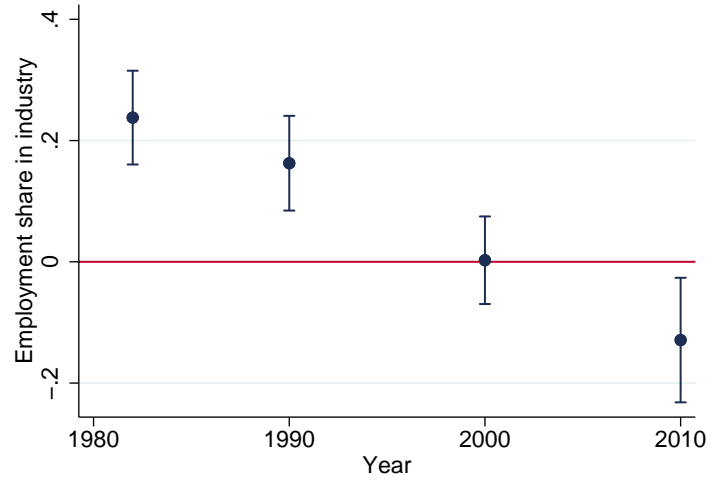

(a) Employment share in industry

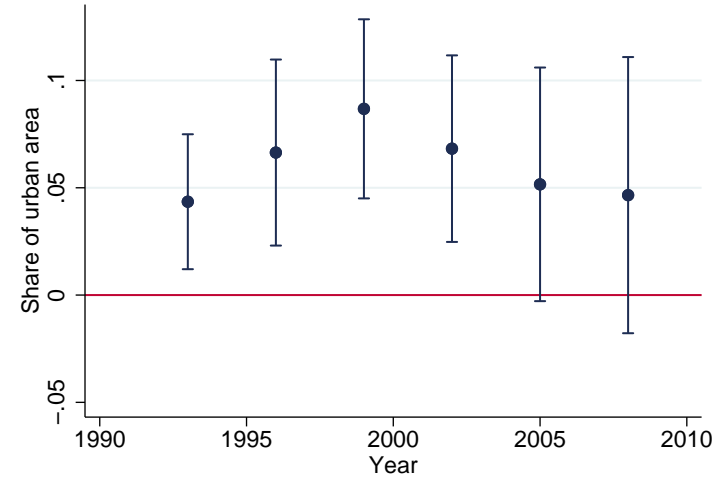

(b) Share of urban area

Notes: This Figure displays the treatment effect for the employment share in industry $(1982,1990,2000,2010)$ and the share of urban area in the county, as computed using impervious surface recognition (1993, 1996, 1999, 2002, $2005,2008)$.

Figure 8. Illustration of the treatment effect over time (Total Factor Productivity, number of patents).

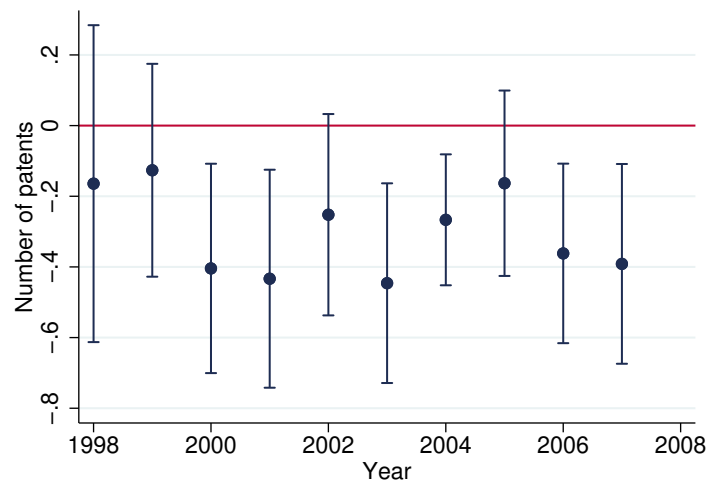

(a) Total Factor Productivity

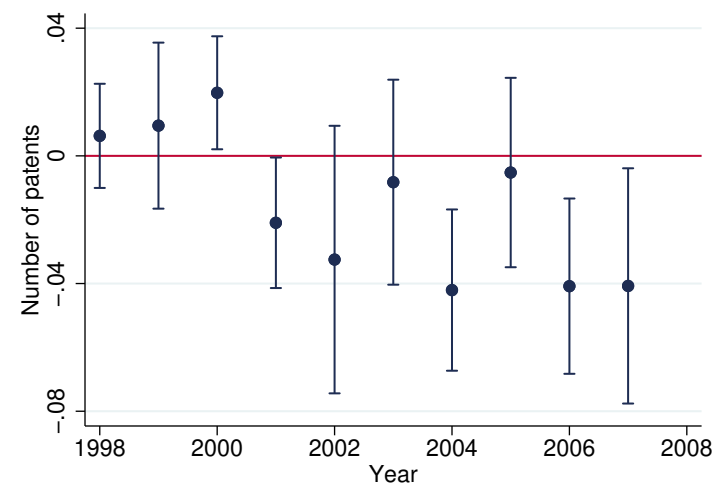

(b) Patents

Notes: This Figure displays the treatment effect for establishments size (1998-2007), and patenting behavior (utility, 1998-2007). 
Figure 9. Illustration of spillovers with treatment heterogeneity.
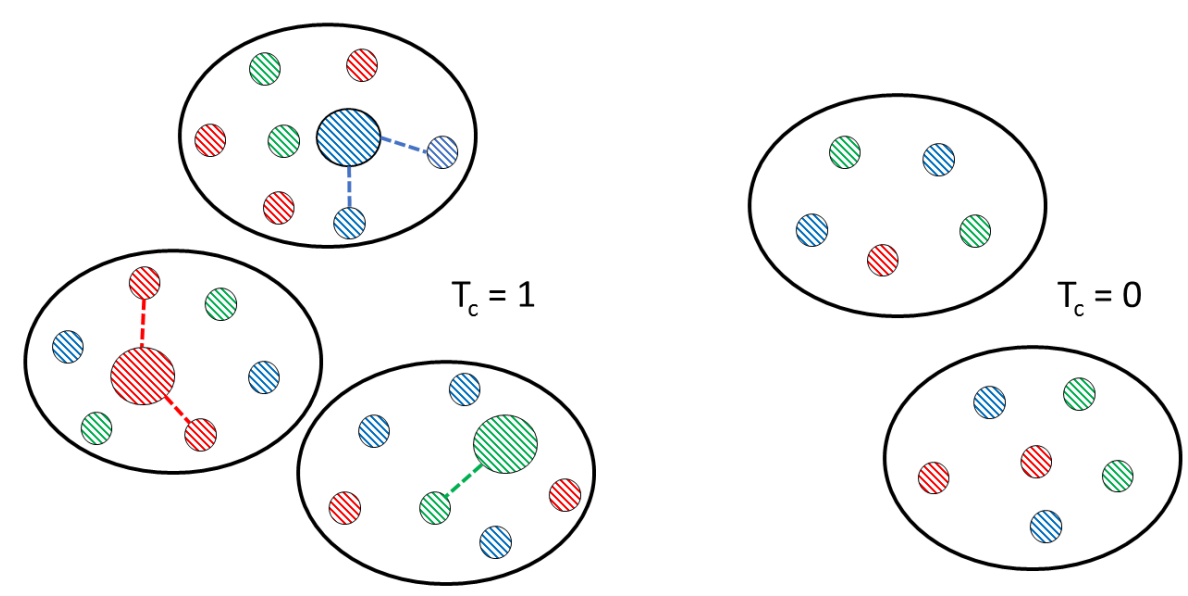
Table 1. Treatment and vulnerability to aerial attacks (1953).

Treatment

Penalized distance
(1)

$\begin{array}{cc}0.143 & 0.148 \\ (0.039) & (0.039)\end{array}$

(2)

0.039

430

Yes

$\mathrm{No}$
0.261

\begin{tabular}{llll} 
Observations & 430 & 430 & 430 \\
Propensity bins & No & Yes & Yes \\
Extended controls & No & No & Yes \\
\hline \hline
\end{tabular}

Notes: Standard errors are clustered at level of 4-degree $\times$ 4-degree cells. The unit of observation is a county (Administrative level 3). Penalized distance is the normalized distance to the main military U.S. and Taiwanese airfields penalized by proximity to U.S.S.R. and North Korean airfields. Extended controls include all matching controls, i.e., travel cost to resources (coal, coke, ore), proximity to a rail hub, whether the county is a provincial capital, population in $1953(\log )$, county area $(\log )$, and additional controls, i.e., travel cost to major ports (through the river network), proximity to Ming-dynasty courier stations, cities in 1900, distance to military airfields) and penalized distance to enemy airfields in 1964. 
Table 2. The 156 Million-Rouble Plants: sector, construction period and initial investment.

\begin{tabular}{|c|c|c|c|c|c|}
\hline \multirow[b]{2}{*}{ Sector } & \multirow[b]{2}{*}{ Number } & \multicolumn{2}{|c|}{ Construction } & \multicolumn{2}{|c|}{ Investment } \\
\hline & & Start & End & Planned & Actual \\
\hline Aviation & 14 & 1953.9 & 1957.3 & 7271 & 7204 \\
\hline Chemical & 7 & 1955.3 & 1958.4 & 15291 & 15474 \\
\hline Coal mining & 25 & 1954.3 & 1958.5 & 5323 & 5832 \\
\hline Electronic & 10 & 1955.5 & 1957.9 & 5661 & 4752 \\
\hline Iron and Steel & 7 & 1953.9 & 1959.0 & 78361 & 84586 \\
\hline Machinery & 23 & 1954.8 & 1958.2 & 9972 & 10336 \\
\hline Nonferrous Metals & 13 & 1955.1 & 1959.0 & 15018 & 15451 \\
\hline Powerplants & 23 & 1954.0 & 1957.9 & 13039 & 9023 \\
\hline Weapons & 16 & 1955.1 & 1958.4 & 13533 & 12262 \\
\hline Other & 12 & 1955.3 & 1959.3 & 11751 & 12513 \\
\hline
\end{tabular}

Notes: Other industries are shipbuilding, pharmaceutical and paper-making industries. The average planned investment by factory was about $100,000,000$ yuan, which amounts to $15,000,000$ Soviet roubles in 1957 ( $\$ 120,000,000$ in 2010 U.S. dollars). Note that some projects were not completed in 1960, and thus abandoned. Some planned projects had not yet been awarded a definitive location, which prevents us from using them as a control group.

Table 3. Descriptive statistics (control and treated counties, weighted by matching weights).

\begin{tabular}{|c|c|c|c|c|}
\hline VARIABLES & Mean & Std dev. & With factory & No factory \\
\hline Vulnerability to air strikes & & & & \\
\hline Penalized distance (1953) & 0.151 & 1.139 & 0.522 & -0.219 \\
\hline $\begin{array}{l}\text { Penalized distance (1964) } \\
\text { Population }\end{array}$ & -0.282 & 0.806 & -0.262 & -0.302 \\
\hline Population $(1953, \log )$ & 12.19 & 1.023 & 12.24 & 12.14 \\
\hline Population (1964, log) & 12.55 & 0.910 & 12.69 & 12.40 \\
\hline Population (1982, log) & 12.94 & 0.845 & 13.08 & 12.81 \\
\hline Population $(1990, \log )$ & 13.07 & 0.817 & 13.20 & 12.94 \\
\hline Population (2000, log) & 13.18 & 0.879 & 13.33 & 13.03 \\
\hline $\begin{array}{l}\text { Population }(2010, \log ) \\
\text { Urban registration }\end{array}$ & 13.27 & 0.930 & 13.42 & 13.13 \\
\hline Share non agr. (1964) & 0.272 & 0.259 & 0.368 & 0.177 \\
\hline Share non agr. (1982) & 0.365 & 0.264 & 0.444 & 0.287 \\
\hline Share non agr. (1990) & 0.405 & 0.279 & 0.481 & 0.330 \\
\hline Share non agr. (2000) & 0.337 & 0.243 & 0.412 & 0.261 \\
\hline $\begin{array}{l}\text { Share non agr. }(2010) \\
\text { Matching controls }\end{array}$ & 0.355 & 0.236 & 0.432 & 0.279 \\
\hline Travel cost to coal mines (log) & 13.20 & 0.750 & 13.18 & 13.22 \\
\hline Travel cost to coke (log) & 13.06 & 0.809 & 12.98 & 13.15 \\
\hline Travel cost to ore (log) & 14.88 & 0.887 & 14.78 & 14.98 \\
\hline Proximity to rail hub & 0.011 & 0.107 & 0.017 & 0.005 \\
\hline Province capital & 0.275 & 0.447 & 0.267 & 0.283 \\
\hline $\begin{array}{l}\text { Area }(\log ) \\
\quad \text { Additional controls }\end{array}$ & 7.23 & 0.762 & 7.24 & 7.22 \\
\hline Proximity to city (1900) & 0.816 & 0.387 & 0.919 & 0.714 \\
\hline Proximity to Ming stations & 0.366 & 0.482 & 0.455 & 0.278 \\
\hline Proximity to rivers & 0.558 & 0.497 & 0.428 & 0.689 \\
\hline Distance to military airfields (log) & 10.41 & 1.038 & 10.28 & 10.54 \\
\hline Travel cost to major ports (log) & 13.88 & 0.881 & 14.03 & 13.73 \\
\hline Observations & \multicolumn{2}{|c|}{430} & 110 & 320 \\
\hline
\end{tabular}

Notes: Penalized distance is standardized (mean 0 and variance 1 over all counties in China). 
Table 4. Treatment effect on employment, output and urbanization in 1982 and 2010.

\begin{tabular}{lcccc}
\hline VARIABLES & $\begin{array}{c}\text { Population } \\
(1)\end{array}$ & $\begin{array}{c}\text { Share urban } \\
(2)\end{array}$ & $\begin{array}{c}\text { GDP p.c. } \\
(3)\end{array}$ & $\begin{array}{c}\text { Share industry } \\
(4)\end{array}$ \\
\hline Panel A: OLS specification & & & & \\
Treatment effect (1982) & .139 & .130 & .291 & $(.070)$ \\
& $(.046)$ & $(.022)$ & {$[430]$} & $(.017)$ \\
Treatment effect $(2010)$ & {$[430]$} & {$[430]$} & & {$[430]$} \\
& .144 & .125 & -.104 & .023 \\
& $(.063)$ & $(.019)$ & $(.079)$ & $(.013)$ \\
& {$[430]$} & {$[430]$} & {$[335]$} & {$[430]$}
\end{tabular}

Panel B: IV specification

Treatment effect (1982)

34.52

Treatment effect (2010)

.253
$(.129)$
$[430]$
34.52

.336
$(.043)$
$[430]$
34.52

.074

Notes: Each cell is the outcome of a separate regression. Standard errors are clustered at level of 4-degree $\times$ 4-degree cells (reported between parentheses). The unit of observation is a county (Administrative level 3); the number of observations is reported between square brackets. The instrument is the distance to the main military U.S. and Taiwanese airfields penalized by the proximity to U.S.S.R. and North Korean airfields; we report the first-stage F-statistics in italic. All specifications include (i) propensity score bins, (ii) matching controls, i.e., travel cost to resources (coal, coke, ore), proximity to a rail hub, whether the county is a provincial capital, population in 1953 $(\log )$, county area $(\log )$, and (iii) the additional controls, i.e., travel cost to major ports (through the river network), proximity to Ming-dynasty courier stations, cities in 1900, distance to military airfields) and penalized distance to enemy airfields in 1964. Population is the logarithm of total population in the county and Share of urban the share of the population that has a non-agricultural household registration (hukou).

Table 5. Structure of firm production (average treatment effect).

\begin{tabular}{|c|c|c|c|c|c|c|}
\hline VARIABLES & $\begin{array}{c}\text { Labor } \\
(1)\end{array}$ & $\begin{array}{c}\text { Capital } \\
(2)\end{array}$ & $\begin{array}{c}\text { Wage } \\
(3)\end{array}$ & $\begin{array}{c}\text { TFP } \\
(4)\end{array}$ & $\begin{array}{c}\text { Patents } \\
(5)\end{array}$ & $\begin{array}{c}\text { Markup } \\
(6)\end{array}$ \\
\hline Treatment & $\begin{array}{c}.301 \\
(.096)\end{array}$ & $\begin{array}{c}.406 \\
(.133)\end{array}$ & $\begin{array}{l}-.320 \\
(.078)\end{array}$ & $\begin{array}{l}-.304 \\
(.104)\end{array}$ & $\begin{array}{l}-.023 \\
(.008)\end{array}$ & $\begin{array}{c}.130 \\
(.062)\end{array}$ \\
\hline Observations & 432,202 & 432,202 & 432,202 & 432,202 & 432,202 & 301,198 \\
\hline
\end{tabular}


Table 6. Treatment heterogeneity along treatment intensity.

\begin{tabular}{lccc}
\hline VARIABLES & $\begin{array}{c}\text { TFP } \\
(1)\end{array}$ & $\begin{array}{c}\text { Patents } \\
(2)\end{array}$ & $\begin{array}{c}\text { Markup } \\
(3)\end{array}$ \\
\hline Panel A: Production linkages & & & \\
Treatment & -.234 & .041 & .003 \\
Treatment $\times$ Production linkages & $(.318)$ & $(.031)$ & $(.428)$ \\
& -.027 & -.031 & .031 \\
& $(.160)$ & $(.016)$ & $(.065)$ \\
Observations & 386,047 & 386,047 & 268,868 \\
\hline Panel B: Different products & & & \\
Treatment & & & -.000 \\
Treatment $\times$ Different products & -.201 & -.026 & $(.095)$ \\
& $(.188)$ & $(.012)$ & .099 \\
Observations & -.267 & .034 & $(.117)$ \\
\hline \hline
\end{tabular}

Notes: Standard errors are clustered at level of 4-degree $\times$ 4-degree cells. The unit of observation is a firm $\times$ year. We exclude the MRPs from the sample. All specifications include the baseline controls (Table 4), 4-digit industry $\times$ year fixed effects, firm type $\times$ year fixed effects and the interaction of the measure of treatment intensity with year fixed effects. 
Table 7. Production linkages with the MRPs.

\begin{tabular}{lccc}
\hline VARIABLES & $\begin{array}{c}\text { Downstream } \\
(1)\end{array}$ & $\begin{array}{c}\text { Upstream } \\
(2)\end{array}$ & $\begin{array}{c}\text { Same product } \\
(3)\end{array}$ \\
\hline \multicolumn{1}{c}{ Panel A: Production linkages } & & \\
Factory & .050 & .067 & .050 \\
& $(.025)$ & $(.023)$ & $(.014)$ \\
& & 432,202 & 432,202 \\
Observations & 432,202 & More K-intensive & More T-intensive \\
VARIABLES & More H-intensive & $(2)$ & $(3)$ \\
\multicolumn{2}{c}{ Panel B: Factor demand } & & .093 \\
& .004 & -.038 & $(.065)$ \\
Factory & $(.085)$ & $(.072)$ & 261,328 \\
& 261,328 & 261,328 &
\end{tabular}

\begin{tabular}{ccc}
\hline VARIABLES & Tech. clos. & Tech. clos. (Mah.) \\
& $(1)$ & $(2)$ \\
\hline
\end{tabular}

Panel C: Technology closeness

$\begin{array}{ccc}\text { Factory } & .019 & -.023 \\ & (.037) & (.040)\end{array}$

Observations $\quad 293,174 \quad 293,174$

Notes: Standard errors are clustered at level of 4-degree $\times$ 4-degree cells. The unit of observation is a firm $\times$ year. We exclude the MRPs from the sample. All specifications include the baseline controls (Table 4), 4-digit industry $\times$ year fixed effects and firm type $\times$ year fixed effects. Downstream (resp. Upstream) is a dummy equal to one if the firm is down (resp. up) the supply chain with respect to one of the 156 factories; Same product is a dummy equal to one if the firm is in the same product market as one of the 156 factories (see Section 4 for a description of the empirical strategy and the definition of these dummies in control counties). More F-intensive is a dummy equal to 1 if the revealed factor intensity of factor $F$ (using product codes) is higher than that of the average associated MRP. Tech. clos. is a dummy equal to one if sectors in which the establishment and the MRP(s) operate are linked through patent applications. 
Table 8. Productivity, innovation, and pricing in establishments along the production chain of MRPs.

\begin{tabular}{lccc}
\hline VARIABLES & TFP & Patents & Markup \\
& $(1)$ & $(2)$ & $(3)$ \\
\hline Panel A: Downstream/Upstream & & & \\
Treatment & -.335 & -.018 & .127 \\
Treatment $\times$ Linkage & $(.105)$ & $(.009)$ & $(.064)$ \\
& .459 & -.095 & .088 \\
Observations & $. .219)$ & $(.055)$ & $(.136)$ \\
\multicolumn{1}{c}{ Panel B: Same product } & 432,202 & 432,202 & 301,198 \\
Treatment & & & \\
Treatment $\times$ Same product & -.316 & & .133 \\
& $(.106)$ & -.023 & $(.063)$ \\
Observations & .443 & $(.009)$ & .160 \\
& $(.346)$ & -.062 & $(.095)$ \\
Nes & & $(.152)$ & 301,198 \\
\hline
\end{tabular}

Notes: Standard errors are clustered at level of 4-degree $\times$ 4-degree cells. The unit of observation is a firm $\times$ year. We exclude the MRPs from the sample. All specifications include the baseline controls (Table 4), 4-digit industry $\times$ year fixed effects and firm type $\times$ year fixed effects. Downstream/Upstream is a dummy equal to one if the firm is down (or up) the supply chain with respect to one of the 156 factories; Same product is a dummy equal to one if the firm is in the same product market as one of the 156 factories (see Section 4 for a description of the empirical strategy and the definition of these dummies in control counties).

Table 9. Emigrant profiles in treated and control counties.

\begin{tabular}{lcccc}
\hline & $\begin{array}{c}\text { University } \\
\text { degree }\end{array}$ & $\begin{array}{c}\text { Manager } \\
\text { position }\end{array}$ & $\begin{array}{c}\text { Self- } \\
\text { employed }\end{array}$ & $\begin{array}{c}\text { Top } \\
\text { income }\end{array}$ \\
\hline Treatment & .772 & .333 & 1.286 & .695 \\
& $(.353)$ & $(.230)$ & $(.328)$ & $(.375)$ \\
Observations & 430 & 430 & 430 & 430 \\
F-stat. (first stage) & 34.52 & 34.52 & 34.52 & 34.52 \\
\hline \hline
\end{tabular}

Notes: Standard errors are clustered at the level of 4-degree $\times$ 4-degree cells. The unit of observation is a county. All specifications include the baseline controls (see Table 4). The dependent variable $Y$ is the share of emigrants with characteristic $Y$, normalized by the share of the population (according to the 2000 population census) with characteristic $Y$. All dependent variables are standardized. University degree is the share of emigrants with a tertiary degree. Manager is the share of emigrants in category 24 ("Managers of Enterprises, Institutions and Related Work Units") of the Chinese Standard Classification of Occupations. Self-employed is the share of emigrants who are own-account workers (this variable is normalized by the share of employed at origin in 2000 , as the 2000 census does not distinguish employment types). Top income is the share of emigrants with incomes in the top quintile of the income distribution in their counties of registration. All outcomes correspond to the emigrant's situation at destination. 
Table 10. Values and aspirations in treated and control counties.

\begin{tabular}{lccc}
\hline & $\begin{array}{c}\text { Master's } \\
\text { degree }\end{array}$ & $\begin{array}{c}\text { No schooling } \\
\text { necessary }\end{array}$ & $\begin{array}{c}\text { Highly esteemed } \\
\text { position }\end{array}$ \\
\hline Panel A: Aspirations & & & \\
Treatment & .075 & -.010 & .123 \\
& $(.021)$ & $(.005)$ & $(.037)$ \\
Observations & 1,838 & 1,838 & 1,838 \\
F-stat. (first stage) & 51.33 & 51.33 & 51.33 \\
\hline & Hard work & Inequality & $\begin{array}{c}\text { Talent is important } \\
\text { for success }\end{array}$ \\
\hline
\end{tabular}

Panel B: Values

$\begin{array}{lccc}\text { Treatment } & -.103 & -.376 & -.546 \\ & (.061) & (.138) & (.241) \\ & & & \\ \text { Observations } & 420 & 420 & 1,838 \\ \text { F-stat. (first stage) } & 39.64 & 39.64 & 51.33\end{array}$

Notes: Standard errors are clustered at the level of 4-degree $\times$ 4-degree cells. The unit of observation is an individual. All specifications include individual and household controls: respondent's age and gender, and household mean income and education (shares of household members at each level of education). The dependent variables are dummy-coded, except "Talent is important for success," which is expressed on a 0-10 scale. Some outcomes are only available for subsamples. 


\section{ONLINE APPENDIX - not for publication}

$\begin{array}{ll}\text { A Additional figures and tables } & 54\end{array}$

B Description of the "156" program $\quad 59$

B.1 Historical context . . . . . . . . . . . . . . . . . . . . . . . 59

B.2 The "156" program . . . . . . . . . . . . . . . 61

B.3 Evolution of the plants and later place-based policies . . . . . . . . 64

$\begin{array}{ll}\text { C Vulnerability to air strikes } & 68\end{array}$

C.1 Allied and enemy airbases over time . . . . . . . . . . . . 68

C.2 Flying cost and penalty . . . . . . . . . . . . . . . . . 69

C.3 Vulnerability maps . . . . . . . . . . . . . . . . . . . . . . 71

D Data description $\quad \mathbf{7 2}$

D.1 Measures of factor productivity . . . . . . . . . . . . . . 72

D.2 Registered patents . . . . . . . . . . . . . . . . . 73

D.3 Measures of markups . . . . . . . . . . . . . . . . . . . . 73

E Additional outcomes, robustness checks and sensitivity analysis $\quad \mathbf{7 5}$

E.1 Detailed treatment effects on the structure of production . . . . . . 75

E.2 Sensitivity analysis . . . . . . . . . . . . . . . 77

F $\quad$ Firm comparison within treated places $\quad 83$ 


\section{A Additional figures and tables}

Table A1. Description of control variables.

\begin{tabular}{|c|c|}
\hline VARIABLES & Description \\
\hline \multicolumn{2}{|l|}{ Population } \\
\hline Population (1953) & $\begin{array}{l}\text { Total population of the county in the First Chinese Popu- } \\
\text { lation Census (1953). }\end{array}$ \\
\hline \multicolumn{2}{|l|}{ Access to resources } \\
\hline Travel cost to coal mines & Distance to coal mines following the 1948 railroad network. \\
\hline Travel cost to ore & $\begin{array}{l}\text { Distance to ore deposits following the } 1948 \text { railroad net- } \\
\text { work. }\end{array}$ \\
\hline Travel cost to coke & $\begin{array}{l}\text { Distance to coke deposits following the } 1948 \text { railroad net- } \\
\text { work. }\end{array}$ \\
\hline \multicolumn{2}{|l|}{ Topographic controls } \\
\hline Slope (degrees) & Average slope in the county. \\
\hline Strong slope & $\begin{array}{l}\text { Dummy equal to } 1 \text { if the average slope is greater than } 10 \\
\text { degrees. }\end{array}$ \\
\hline Elevation (mean; m) & Average elevation in the county (in meters). \\
\hline Elevation (st. dev.; m) & Standard deviation of elevation in the county (in meters). \\
\hline \multicolumn{2}{|l|}{ Market access controls } \\
\hline Travel cost to ports & $\begin{array}{l}\text { Dummy equal to } 1 \text { for a county whose centroid is lying } \\
\text { within } 500 \mathrm{~km} \text { of a port following navigable waterways, } \\
\text { and } 0 \text { otherwise. }\end{array}$ \\
\hline Proximity to courier stations & $\begin{array}{l}\text { Dummy equal to } 1 \text { if the county centroid is located within } \\
10 \mathrm{kms} \text { of the closest Ming-dynasty courier station. }\end{array}$ \\
\hline Proximity to 1900 city & $\begin{array}{l}\text { Dummy equal to } 1 \text { if the county centroid is located within } \\
10 \mathrm{kms} \text { of the closest city as of } 1900 .\end{array}$ \\
\hline Proximity to rivers & $\begin{array}{l}\text { Dummy equal to } 1 \text { if the county centroid is located within } \\
10 \mathrm{kms} \text { of a major river. }\end{array}$ \\
\hline Proximity to railway hub & $\begin{array}{l}\text { Dummy equal to } 1 \text { if the county centroid is located within } \\
5 \mathrm{kms} \text { of a railway hub. }\end{array}$ \\
\hline Dist. to the coast & Minimum distance to the coast. \\
\hline Province capital & $\begin{array}{l}\text { Dummy equal to } 1 \text { if the county belongs to the capital of } \\
\text { the province. }\end{array}$ \\
\hline \multicolumn{2}{|l|}{ Geomorphic controls } \\
\hline Lake plain & Share of the county's area that consists of lacustrine plains. \\
\hline Sand hills & Share of the county's area that consists of sand hills. \\
\hline Tidal marsh & Share of the county's area that consists of tidal marshes. \\
\hline \multicolumn{2}{|l|}{ Agricultural controls } \\
\hline Expected yield: maize & $\begin{array}{l}\text { Average potential yield ( } \mathrm{kg} / \mathrm{ha} \text { ) of maize under the high- } \\
\text { input scenario (GAEZ model-based). }\end{array}$ \\
\hline Expected yield: rice & $\begin{array}{l}\text { Average potential yield ( } \mathrm{kg} / \mathrm{ha}) \text { of rice under the high- } \\
\text { input scenario (GAEZ model-based). }\end{array}$ \\
\hline Expected yield: wheat & $\begin{array}{l}\text { Average potential yield (kg/ha) of wheat under the high- } \\
\text { input scenario (GAEZ model-based). }\end{array}$ \\
\hline \multicolumn{2}{|l|}{ Other geographic controls } \\
\hline Area & Total land area of the county. \\
\hline Dist. to military airfields & Minimum distance to a Chinese military airfield. \\
\hline
\end{tabular}


Table A2. Treatment and vulnerability to aerial attacks (1964, 1972).

Treatment

Penalized distance (1964)

$(0.137)$

Penalized distance (1972)

Observations

430

430

Propensity bins

Yes

Yes

Extended controls

Yes

Yes

Notes: Standard errors are clustered at level of 4-degree $\times$ 4-degree cells. The unit of observation is a county (Administrative level 3). Penalized distance is the normalized distance to the main enemy airfields penalized by proximity to allied airfields (in 1964 and in 1972). Extended controls include all matching controls, i.e., travel cost to resources (coal, coke, ore), proximity to a rail hub, whether the county is a provincial capital, population in $1953(\mathrm{log})$, county area $(\mathrm{log})$, and additional controls, i.e., travel cost to major ports (through the river network), proximity to Ming-dynasty courier stations, cities in 1900, distance to military airfields).

Table A3. Vulnerability to aerial attacks (1953) and place-based policies (Third-Front movement and city parks).

\begin{tabular}{lcc}
\hline Treatment & Third-Front & City park \\
& $(1)$ & $(2)$ \\
Penalized distance & & \\
& 0.057 & 0.013 \\
& $(0.031)$ & $(0.064)$
\end{tabular}

Observations

Propensity bins

Yes

Yes

Extended controls

Yes

Yes

Notes: Standard errors are clustered at level of 4-degree $\times$ 4-degree cells. The unit of observation is a county (Administrative level 3). Penalized distance is the normalized distance to the main enemy airfields penalized by proximity to allied airfields (in 1953). Extended controls include all matching controls, i.e., travel cost to resources (coal, coke, ore), proximity to a rail hub, whether the county is a provincial capital, population in 1953 (log), county area $(\log )$, and additional controls, i.e., travel cost to major ports (through the river network), proximity to Ming-dynasty courier stations, cities in 1900, distance to military airfields) and penalized distance to enemy airfields in 1964. Third-Front is a dummy equal to one if the county is in a province chosen as part of the Third-Front movement; City park is the total number of city parks created between 1980 and 2005 per 10,000 inhabitants. 
Table A4. Sensitivity to the empirical specification (matching and weights).

\begin{tabular}{|c|c|c|c|c|}
\hline VARIABLES & $\begin{array}{c}\text { Population } \\
(1982)\end{array}$ & $\begin{array}{c}\text { GDP p.c. } \\
(1982)\end{array}$ & $\begin{array}{c}\text { Population } \\
(2010)\end{array}$ & $\begin{array}{c}\text { GDP p.c. } \\
(2010)\end{array}$ \\
\hline \multicolumn{5}{|c|}{ Panel A: Local identification } \\
\hline Treatment effect & $\begin{array}{c}.142 \\
(.046) \\
{[2,321]}\end{array}$ & $\begin{array}{c}.427 \\
(.085) \\
{[2,321]}\end{array}$ & $\begin{array}{c}.242 \\
(.065) \\
{[2,321]}\end{array}$ & $\begin{array}{c}-.016 \\
(.093) \\
{[2,029]}\end{array}$ \\
\hline \multicolumn{5}{|c|}{ Panel B: Matching with extended variables } \\
\hline Treatment effect & $\begin{array}{c}.067 \\
(.107) \\
{[407]}\end{array}$ & $\begin{array}{c}.793 \\
(.202) \\
{[407]}\end{array}$ & $\begin{array}{c}.183 \\
(.084) \\
{[407]}\end{array}$ & $\begin{array}{c}-.282 \\
(.193) \\
{[312]}\end{array}$ \\
\hline \multicolumn{5}{|c|}{ Panel C: Matching with fewer variables } \\
\hline Treatment effect & $\begin{array}{c}.137 \\
(.113) \\
{[426]} \\
\end{array}$ & $\begin{array}{l}.753 \\
(.229) \\
{[426]} \\
\end{array}$ & $\begin{array}{c}.113 \\
(.107) \\
{[426]} \\
\end{array}$ & $\begin{array}{c}.066 \\
(.373) \\
{[327]} \\
\end{array}$ \\
\hline \multicolumn{5}{|c|}{ Panel D: One-to-one matching } \\
\hline Treatment effect & $\begin{array}{c}.223 \\
(.098) \\
{[222]} \\
\end{array}$ & $\begin{array}{c}.764 \\
(.205) \\
{[222]}\end{array}$ & $\begin{array}{c}.288 \\
(.134) \\
{[222]} \\
\end{array}$ & $\begin{array}{c}.002 \\
(.186) \\
{[158]}\end{array}$ \\
\hline \multicolumn{5}{|c|}{ Panel E: Matching with larger exclusion zone } \\
\hline Treatment effect & $\begin{array}{c}.114 \\
(.083) \\
{[236]} \\
\end{array}$ & $\begin{array}{c}.641 \\
(.267) \\
{[236]} \\
\end{array}$ & $\begin{array}{c}.197 \\
(.143) \\
{[236]} \\
\end{array}$ & $\begin{array}{c}-.305 \\
(.196) \\
{[173]}\end{array}$ \\
\hline \multicolumn{5}{|c|}{ Panel F: No weights } \\
\hline Treatment effect & $\begin{array}{c}.249 \\
(.106) \\
{[430]}\end{array}$ & $\begin{array}{c}.906 \\
(.185) \\
{[430]}\end{array}$ & $\begin{array}{c}.230 \\
(.135) \\
{[430]}\end{array}$ & $\begin{array}{l}-.013 \\
(.272) \\
{[335]}\end{array}$ \\
\hline
\end{tabular}

$\overline{\text { Notes: Each cell is the outcome of a separate regression. Standard errors are clustered at level of 4-degree } \times 4 \text {-degree }}$ cells (reported between parentheses). The unit of observation is a county (Administrative level 3); the number of observations is reported between square brackets. The instrument is the distance to the main military U.S. and Taiwanese airfields penalized by the proximity to U.S.S.R. and North Korean airfields. All specifications include (i) propensity score bins (except Panel A which includes province-fixed effects instead), (ii) matching controls, i.e., travel cost to resources (coal, coke, ore), proximity to a rail hub, whether the county is a provincial capital, population in $1953(\log )$, county area $(\log )$, and (iii) the additional controls, i.e., travel cost to major ports (through the river network), proximity to Ming-dynasty courier stations, cities in 1900, distance to military airfields) and penalized distance to enemy airfields in 1964. Population is the logarithm of total population in the county. In Panel B, we use proximity to Ming stations, distance to military airfields and access to the main trading ports as matching variables in order to select the group of control counties. In Panel C, we drop access to ore and coke from the set of matching variables. 
Table A5. Sensitivity to the empirical specification (exclusion restriction).

\begin{tabular}{ccccc}
\hline VARIABLES & $\begin{array}{c}\text { Population } \\
(1982)\end{array}$ & $\begin{array}{c}\text { GDP p.c. } \\
(1982)\end{array}$ & $\begin{array}{c}\text { Population } \\
(2010)\end{array}$ & $\begin{array}{c}\text { GDP p.c. } \\
(2010)\end{array}$ \\
\hline \multicolumn{5}{c}{ Panel A: Excluding closed and displaced factories } \\
Treatment effect & .178 & .747 & & \\
& $(.106)$ & $(.192)$ & .142 & -.244 \\
& {$[417]$} & {$[417]$} & {$[.124)$} & $(.213)$ \\
\end{tabular}

Panel B: Excluding a buffer around the Pearl river delta

\begin{tabular}{|c|c|c|c|c|}
\hline Treatment effect & $\begin{array}{c}.358 \\
(.194) \\
{[391]}\end{array}$ & $\begin{array}{c}1.26 \\
(.360) \\
{[391]}\end{array}$ & $\begin{array}{c}.644 \\
(.271) \\
{[391]}\end{array}$ & $\begin{array}{c}.081 \\
(.196) \\
{[302]}\end{array}$ \\
\hline \multicolumn{5}{|c|}{ Panel C: Excluding the South of China } \\
\hline Treatment effect & $\begin{array}{c}.137 \\
(.113) \\
{[316]}\end{array}$ & $\begin{array}{c}.753 \\
(.229) \\
{[316]} \\
\end{array}$ & $\begin{array}{c}.113 \\
(.107) \\
{[316]}\end{array}$ & $\begin{array}{c}-.120 \\
(.308) \\
{[236]}\end{array}$ \\
\hline Treatment effect & $\begin{array}{c}.191 \\
(.135) \\
{[430]}\end{array}$ & $\begin{array}{c}.770 \\
(.259) \\
{[430]}\end{array}$ & $\begin{array}{c}.195 \\
(.177) \\
{[430]}\end{array}$ & $\begin{array}{c}.232 \\
(.270) \\
{[335]}\end{array}$ \\
\hline
\end{tabular}

Panel E: Controls for unfavorable environment (elevation etc.)

\begin{tabular}{ccccc} 
Treatment effect & .247 & .591 & .202 & -.265 \\
& $(.140)$ & $(.198)$ & $(.162)$ & $(.165)$ \\
& {$[353]$} & {$[353]$} & {$[353]$} & {$[282]$} \\
\hline
\end{tabular}

Panel F: Controls for other policies (Third Front, SEZs etc.)

\begin{tabular}{ccccc} 
Treatment effect & .127 & .908 & .152 & .154 \\
& $(.100)$ & $(.220)$ & $(.123)$ & $(.214)$ \\
& {$[430]$} & {$[430]$} & {$[430]$} & {$[335]$} \\
\hline
\end{tabular}

Panel G: Controls for vulnerability to U.S.S.R. strikes (1972)

$\begin{array}{ccccc}\text { Treatment effect } & .598 & .890 & .685 & -1.22 \\ & (.211) & (.317) & (.253) & (.404) \\ & {[430]} & {[430]} & {[430]} & {[335]}\end{array}$

$\overline{\text { Notes: Each cell is the outcome of a separate regression. Standard errors are clustered at level of 4-degree } \times 4 \text {-degree }}$ cells (reported between parentheses). The unit of observation is a county (Administrative level 3); the number of observations is reported between square brackets. The instrument is the distance to the main military U.S. and Taiwanese airfields penalized by the proximity to U.S.S.R. and North Korean airfields. All specifications include (i) propensity score bins, (ii) matching controls, i.e., travel cost to resources (coal, coke, ore), proximity to a rail hub, whether the county is a provincial capital, population in 1953 (log), county area (log), and (iii) the additional controls, i.e., travel cost to major ports (through the river network), proximity to Ming-dynasty courier stations, cities in 1900, distance to military airfields) and penalized distance to enemy airfields in 1964. 
Table A6. Sensitivity to other measures of economic development.

\begin{tabular}{lccc} 
VARIABLES & Participation & Illiteracy rate & Male/female ratio \\
\hline Panel A: Additional census variables & & \\
Treatment effect (1982) & -.040 & -.163 & -.015 \\
& $(.022)$ & $(.041)$ & $(.017)$ \\
& {$[430]$} & {$[430]$} & {$[430]$}
\end{tabular}

\begin{tabular}{lccc} 
VARIABLES & Agriculture & Industry & Services \\
\hline Panel B: Precise sectoral decomposition (employment shares) & \\
Treatment effect (1990) & -.267 & .126 & .136 \\
& $(.067)$ & $(.039)$ & $(.034)$ \\
& {$[430]$} & {$[430]$} & {$[430]$} \\
Treatment effect $(2010)$ & .042 & -.129 & .086 \\
& $(.060)$ & $(.052)$ & $(.033)$ \\
& {$[430]$} & {$[430]$} & {$[430]$} \\
\hline
\end{tabular}

VARIABLES Nightlights (1993) Nightlights (2012) Urban (1993)

Panel C: Satellite data

\begin{tabular}{|c|c|c|c|}
\hline Treatment effect & $\begin{array}{c}1.21 \\
(.336) \\
{[430]}\end{array}$ & $\begin{array}{c}.524 \\
(.258) \\
{[430]}\end{array}$ & $\begin{array}{c}.043 \\
(.016) \\
{[423]}\end{array}$ \\
\hline VARIABLES & Expenditures & Revenues & Savings \\
\hline \multicolumn{4}{|c|}{ Panel D: Local governments } \\
\hline Treatment effect & $\begin{array}{c}-.147 \\
(.217) \\
{[299]}\end{array}$ & $\begin{array}{c}-.993 \\
(.399) \\
{[299]}\end{array}$ & $\begin{array}{c}-.137 \\
(.284) \\
{[299]}\end{array}$ \\
\hline
\end{tabular}

$\overline{\text { Notes: Each cell is the outcome of a separate regression. Standard errors are clustered at level of 4-degree } \times \text { 4-degree }}$ cells (reported between parentheses). The unit of observation is a county (Administrative level 3); the number of observations is reported between square brackets. The instrument is the distance to the main military U.S. and Taiwanese airfields penalized by the proximity to U.S.S.R. and North Korean airfields. All specifications include (i) propensity score bins (except Panel A which includes province-fixed effects instead), (ii) matching controls, i.e., travel cost to resources (coal, coke, ore), proximity to a rail hub, whether the county is a provincial capital, population in $1953(\log )$, county area (log), and (iii) the additional controls, i.e., travel cost to major ports (through the river network), proximity to Ming-dynasty courier stations, cities in 1900, distance to military airfields) and penalized distance to enemy airfields in 1964 . 


\section{B Description of the " 156 " program}

In this section, we provide additional information about the "156" program. First, we summarize the historical context and geopolitical background. Second, we present the Sino-Soviet cooperation during the First Five-Year Plan, the characteristics of the plants built under the program and discuss how the sites were selected. Finally, we review the evolution of the Million-Rouble plants and other place-based policies after the end of the First Five-Year Plan.

\section{B.1 Historical context}

Leaning to one side When the People's Republic was established in 1949, World War II and the civil war had left China a poverty-stricken agrarian country. The new Communist regime was isolated, as the Western world recognized Chiang Kaishek's Taiwan-based power as the legitimate representative of China. To ensure national security and economic prosperity in such context, Chinese leaders planned to industrialize the economy rapidly, prioritizing heavy industry as the basis of production. ${ }^{39}$ China lacked resources to develop its industry, and turned to the Soviet Union. Despite ideological proximity, economic cooperation with the U.S.S.R. was not obvious. Pre-1949 economic relationships between the two countries were thin, and the Komintern had repeatedly talked the Chinese Communists into supporting the Nationalists, which they then saw as the only political force able to rule China. The Soviet Union was however the only advanced economy China could turn to in the 1950s. Washington and its allies imposed an embargo that prevented Communist China from importing the technology and resources needed to develop its industrial base (Zhang, 2001). The subsequent alliance with the U.S.S.R., which Chairman Mao called "leaning to one side" (June 30, 1949), was further reinforced by the Korean War, which the U.S.S.R. fought vicariously through a Chinese "People's Volunteer Army" of 250,000 men.

Sino-Soviet cooperation On February 14, 1950, the Treaty of Friendship and Alliance was signed between China and the U.S.S.R. A series of agreements ensued, paving the way for a comprehensive economic and scientific cooperation that spanned China's First and half of its Second Five-Year Plans (1953-1957 and 1958-1962).

The cooperation between Communist China and the Soviet Union assumed two main aspects: scientific and economic, both embodied in the "156" program. Soviet

\footnotetext{
${ }^{39}$ In the words of future Premier Zhou Enlai, "without heavy industry, there will be no foundation for the national industry" (January 1942).
} 
experts would be dispatched to China to advise Chinese planners. At the peak of the Sino-Soviet alliance, 20,000 experts were present in China (Zhang, 2001; Wang, 2003). Although Soviet experts were involved in all aspects of central planning, in particular during the First Five-Year Plan, their presence was the most crucial for the "156" program. They were responsible for the design and construction of the plants, and they also trained Chinese cadres and workers to run the factories and operate and maintain equipment. To ensure the sustainability of the program, 80,000 Chinese students were sent to Soviet universities and technological institutes, with the perspective of a position in one of the plants upon return.

Economic cooperation involved technology and financial transfers. Technology transfer was a major component of the "156" program in particular. The equipment supplied by the U.S.S.R. was among the most advanced at the time (Lardy, 1987). ${ }^{40}$ Blueprints and technical documents for production were shared with Chinese engineers free of charge, ${ }^{41}$ allowing China to gradually absorb and adapt Soviet technologies (Xiao, 2014). In the agreements that created the "156" program, the Soviet Union committed to carrying out all the design work, from choosing the sites to implementing the design, providing the required equipment and supervising construction, as well as overseeing new product manufacturing and training ordinary workers, technicians and all necessary cadres. ${ }^{42}$

The financial resources provided to China by the U.S.S.R. mostly consisted of loans. During his first visit to the U.S.S.R., Chairman Mao negotiated a $\$ 300,000,000$ loan at the preferential rate of $1 \%$ per annum, which financed part of the " 156 " program. China was also to reimburse the Soviet Union for the construction of the plants by providing 160,000 tons of tungsten concentrate, 110,000 tons of tin, 35,000 tons of molybdenum concentrate, 30,000 tons of antimony, 90,000 tons of rubber, and other produce including wool, rice or tea (Dong, 1999). Some low-skilled workers were also sent to Siberia. Besides loans, Soviet cooperation did however involve an aid component. Technological cooperation implied free transfers of blueprints and documents, the monetary value of which should not be downplayed. The U.S.S.R. also granted China product manufacturing patents that alone represented a value of about 3-3.5 million roubles (Dong, 1999).

\footnotetext{
${ }^{40}$ The last 15 projects agreed on in 1954 as part of the " 156 " program benefited from state-ofthe-art equipment that few Soviet factories enjoyed (Goncharenko, 2002).

${ }^{41}$ See "Agreement on aid from the U.S.S.R. government to the P.R.C. government to develop the Chinese national economy" (May 15, 1953).

${ }^{42}$ The U.S.S.R. provided between $50 \%$ and $70 \%$ of the total value of the equipments necessary to build the plants (Dong, 1999). The remainder could be produced locally and was thus not covered by Soviet cooperation. See Chinese Academy of Social Sciences and State Archives Administration (1998).
} 


\section{B.2 The "156" program}

Chronology The "156" program was decided through three agreements. The first 50 plants were negotiated during Chairman Mao's first visit to the U.S.S.R. (Winter 1949/50). On May 15, 1953, Li Fuchun and Anastas Mikoyan signed the "Agreement on aid from the U.S.S.R. government to the P.R.C. government to develop the Chinese national economy." The parties agreed on building 91 additional industrial projects, and the 141 plants were to be built between 1953 and 1959. ${ }^{43}$ In October 1954, Khrushchev visited Beijing and signed with his Chinese counterpart a protocol to build 15 additional industrial plants, completing the Soviet-sponsored "156" program. A total of 150 plants were complete and operational by 1960 (Dong and $\mathrm{Wu}, 2004)$. Because 156 projects had initially been touted, speeches and reports continued to refer to the " 156 " program.

Characteristics of the plants The industrial cooperation spanned a wide range of sectors (including aircraft, machinery, electronic industry, and weapons), with a priority for heavy industry. Table 2 summarizes the distribution of the plants by industrial sector. A majority of plants operate in the heavy, extractive and energy sectors. China had the experience and capacity to build most light-industry factories, so that Soviet cooperation concentrated on sectors that China lacked the skills and wherewithal to develop. Military-related industries made up a fifth of the plants, reflecting geopolitical concerns in the 1950s.

The Million-Rouble plants brought about a large technological shift. The sheer size of the investments and their focus on industry was meant to transform China from a subsistence-farming to an industrial economy. The average plant constituted an investment of 130,000,000 yuan or 19,500,000 Soviet roubles in 1957, which is the equivalent of $\$ 156,000,000$ in 2010 U.S. dollars. Some plants "produced many new products that China had never produced in history" (Li, 1955a), e.g., the Luoyang Truck Factory which produced China's first truck (see Figure B1 for a view of what is now YTO Group Corporation).

Location decisions One of the main tasks of the Soviet experts was to help determine the optimal location for the plants (Li, 1955b). Bo Yibo, a prominent leader personally involved in the design of the "156" program, outlines four main criteria guiding the location decision process (Bo, 1991). Plants had to be built close to natural resources to reduce transportation costs and avoid waste. Places

\footnotetext{
${ }^{43}$ Construction work began on average in 1954 and was completed in 1958. Mean start and end dates by sector are provided in Table 2 .
} 
Figure B1. Contemporary view of the Luoyang Truck Factory.

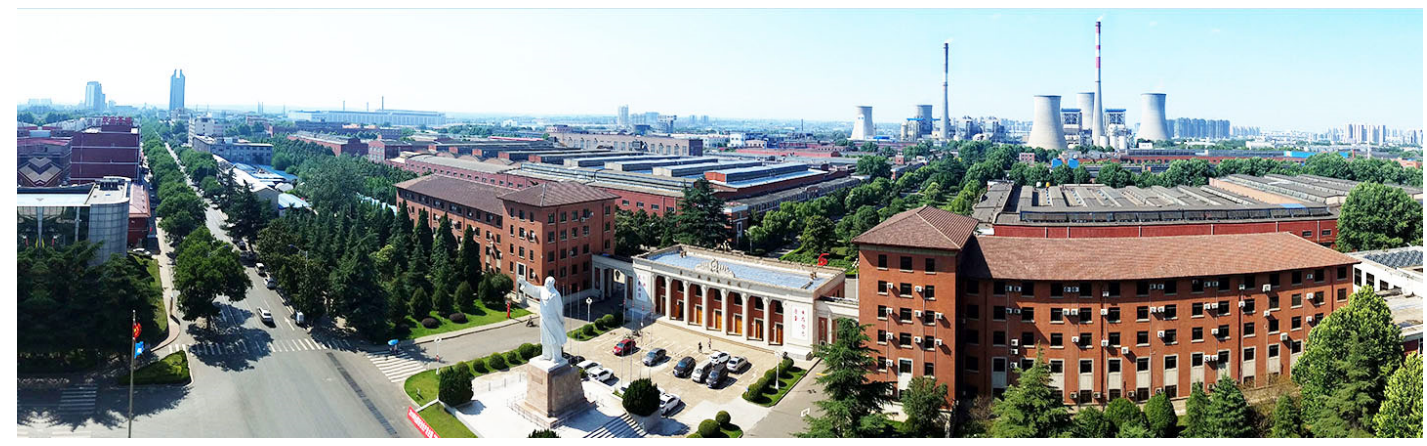

Note: This figure reproduces a contemporary view of the Luoyang Truck Factory, now YTO Group Corporation. In the foreground, we can see the buildings of the Luoyang Truck Factory, constructed as part of the "156" program. Source: YTO Group Corporation website [http://www.yituo.com.cn/; accessed September 11, 2018].

easily accessible through the road and railway network should be favored, so as to reach down- and upstream firms and end-consumer markets at a lower cost. Regions with no pre-existing industrial base would be given priority. Conditional on meeting these first criteria, state-of-the-art Soviet-sponsored plants were to be built out of the reach of U.S. and Taiwanese bombers.

The first two criteria were meant to select optimal locations from an economic point of view. Numerous Soviet textbooks on factory location choice were translated and adapted in 1950s China, and the text of the First Five-Year Plan contains a whole section on rational plant location based on geography. A Russian-Chinese thesaurus with a special focus on factory location choice was also published. Soviet plant location textbooks emphasized the importance of pre-selecting several locations, comparing them based on a list of objective criteria and making field trips to the short-listed sites. Among the main criteria were easy access to natural resources, transportation network and market access.

The third criterion does not appear as a goal in its own right in other sources. A significant share of the " 156 " plants were built in previously agrarian regions, but possibly because the threat of U.S. and Taiwanese air strikes called for industrializing the hinterland. This third criterion is however a common feature of place-based policies, as policy makers are often willing to correct perceived inequalities in the spatial distribution of economic activity.

Soviet experts recommended, in order to minimize costs, that priority be given to expanding existing plants. Stalin expressed this idea himself in a 1952 conversation with Zhou Enlai, ${ }^{44}$ although he also advised the Chinese to build new plants, in

\footnotetext{
44 "Minutes of Conversation between I.V. Stalin and Zhou Enlai," September 03, 1952, History and Public Policy Program Digital Archive, APRF, f. 45, op. 1, d. 329, 1l. 75-87. Translated by
} 
particular defense industry factories, far away from the coast and borders, a lesson the U.S.S.R. had bitterly learnt in World War II. Chairman Mao was apparently responsible for making military security a major tenet of the "156" program (Xia, 2008). ${ }^{45}$ An example of the attention paid to military security is the Rehe Vanadium and Titanium Factory, originally located at Nü'erhe, near Jinzhou, Liaoning province. On May 16, 1955, the Heavy Industry Department issued a report arguing that this location, about 10 kilometers from the Gulf of Bohai, did not follow closely enough the "not building, not expanding in coastal areas" principle. They instead recommended that Soviet experts reconsider the site. The plant was eventually built in Shuangtashan, near Chengde, Rehe (today, Hebei) province, 100 kilometers away from the sea (Chinese Academy of Social Sciences and State Archives Administration, 1998). Most Million-Rouble plants were constructed along this "Second Front".

In 1953, China's aviation was non-existent, which explains the importance of Soviet military protection ${ }^{46}$ The People's Liberation Army only developed an aviation thanks to Soviet support and because of the pressing needs of the Korean War. One of its pioneer pilots and later vice-commander of the Nanjing Air Command, recalled that "when Chairman Mao declared that China would join the Korean War, the Chinese air force did not have one operational unit that could [be] put into the air" (Bergin, 2013). Even after the Korean War, China's air force was recognized as woefully inadequate. ${ }^{47}$ The Chinese government would thus shelter the brand new "156" plants close to allied airbases. The 1950 Treaty of Friendship and Alliance indeed assured them that the Soviet Union would defend China in case of foreign aggression. Bo, who was personally involved in plant location decisions, reports that senior military officials took part in the deliberations: "when examining plant locations, [they] would place plant sites on a map", along with all U.S. bases in Taiwan, South Korea and Japan, to determine "which types of American planes could attack which sites" (Bo, 1991).

Danny Rozas. Available at http://digitalarchive.wilsoncenter.org/document/111242.

${ }^{45}$ The concern with enemy attacks of the new plants can also be seen from the pages of the Russian-Chinese Technical Thesaurus: with reference to factory location choice (1954): "Shelter, air-raid dugout" unexpectedly features among the characteristics that a factory must have.

${ }^{46}$ Whatever was left from World War II was either taken to Taiwan or sabotaged by the Nationalists before their exile. Chongqing's Baishiyi airfield, for instance, fell victim to such scorched-earth policy and could not be used between 1949 and 1959, when it was eventually rebuilt.

${ }^{47}$ Another of China's first pilots interviewed by Bergin, and later chief pilot of China's first indigenous aircraft, recounts that "Soviet Premier Nikita Khrushchev said that without Soviet help, the Chinese air force would become a Chinese ground force in three months" (Bergin, 2013). 


\section{B.3 Evolution of the plants and later place-based policies}

This paper studies the effect of the Million-Rouble plants over the long run; it is thus critical to understand what they became after the end of the First Five-Year Plan (1953-1957). In what follows, we describe the evolution of the MRPs through the end of the First Five-Year Plan, the Sino-Soviet split, the Cultural Revolution and the introduction of economic reforms.

End of the First Plan The Sino-Soviet cooperation survived beyond the First Five-Year Plan: 102 of the "156"-program plants became operational during the Second Five-Year Plan, not so much due to delays as to the original agreements between Beijing and Moscow. Two similar agreements were signed on August 8, 1958 and February 7, 1959 to expand Sino-Soviet cooperation and build 125 additional large plants, which were to be built during the Second and Third Five-Year Plans. The 1960 split however curtailed this second wave of investments. The "156" plants constitute the only large-scale industrialization program carried out in China thanks to Soviet cooperation.

Sino-Soviet split Sino-Soviet relations were strained in the late 1950s by rapid ideological divergence. After Stalin's death, ideological and political tensions started to rise with Khrushchev's condemnation of his predecessor's crimes in 1956 and his policy of "peaceful coexistence with the West." As China kept encouraging a Stalinlike cult of Mao's personality and pursued aggressive foreign policy, the normalization of the Soviet regime and prospect of détente between the two superpowers could only worry Chinese leaders.

The Sino-Soviet split materialized in 1960 when Soviet experts and Chinese students were suddenly repatriated. Incomplete projects that were not viable were abandoned, while future investments were canceled. Six of the "156" plants were not operational and could not be completed without Soviet support and were closed. The split induced a dramatic shift in China's alliances and conception of national security. The sites that had been carefully selected because they could benefit from Soviet or North Korean protection now appeared vulnerable. Subsequently, Mao launched in 1964 the "Third Front Movement" (Sanxian jianshe), a new wave of industrial investments (mostly in heavy industry) directed at remote inland areas.

Third Front Movement The Third Front Movement, which covers the period 1964-1980, is notorious for the costly moving of plants and workers, from sensible locations to places "close to mountains, dispersed and hidden" (kaoshan, fensan, 
yinbi). Such spectacular moves were however the exception rather than the norm: they should be restricted to strategic military industries, remain exceptional and not be carried out on a large scale. ${ }^{48}$ "First-front" industries (on the coast and in major cities) would be affected, as they were deemed the most vulnerable to foreign attacks, while the "second-front" industries, to which the "156" factories belong, had been recently built. The motto for the "156" plants was therefore to continue developing them as previously planned. Three plants built under the " 156 " program were however entirely or partly moved. A first check of the robustness of the rise and fall pattern observed in the paper is to exclude these displaced investments (see Appendix Table A5, Panel A). In this exercise, we also exclude 15 Million-Rouble plants that closed down during the reform era; almost all of them operated in the extractive sector and went into liquidation because of the depletion of the natural resource they exploited.

A concern with the Third Front Movement is that, although second-front industries, and the "156" plants in particular, were largely unaffected, massive investments were directed toward other provinces, which may have hurt the economic environment of the Million-Rouble plants. To check whether Third Front investments diverted resources away from the treated counties and explain their decline in the second period, we use the list of Third Front province from Fan and Zou (2015). Table A5, Panel F, controls for concurrent policies and includes an indicator variable equal to 1 if a county belongs to a such a province and 0 otherwise. We find that this control does not alter the results.

The Third Front Movement and "156" program both incorporated military imperatives in plant location decisions, but they were designed in different geopolitical situations. We show the induced variation in vulnerability in Figure 4, and we condition for the later vulnerability in our baseline specification. ${ }^{49}$

Cultural Revolution A few years after the construction of the Million-Rouble plants had been achieved, Chairman Mao launched the "Great Proletarian Cultural Revolution." This movement, which officially lasted between 1966 and 1976, triggered a period of political turmoil that mostly affected urban areas and large enterprises. Industry valued added dropped from 44.6 to 12.6 million Chinese yuan

\footnotetext{
${ }^{48}$ Comrade Fuchun's summary report to the National Planning Meeting, October 20, 1964.

${ }^{49}$ In the right panel of Figure 4, we measure vulnerability in 1964, at the onset of the Third Front Movement. The effects are similar if we control for a milder version of 1964 vulnerability, considering U.S.S.R. and North Korean as neutral rather than as threats. We also find the same rise-and-pattern if we control for vulnerability to U.S. or Taiwanese bombings in 1990, i.e., following the collapse of the Soviet Union and using the locations of airbases in that year. (Results available upon request.)
} 
(in constant 1990 prices) between 1966 and 1967, and it would not recover until 1980 (Dong and Wu, 2004). Because they were more industrialized, the counties treated under the "156" program may have suffered disproportionately from the Cultural Revolution, and the disorganization of production may have affected their trajectory beyond 1976, leading to the rise-and-fall pattern that we observe.

To control for the effect of the Cultural Revolution, we use data collected from 2,213 local annals (difang zhi) - see Walder (2014). Information about the number of "casualties" from the Cultural Revolution was culled from the historical narratives included in the annals. "Casualties" can be divided into two categories: the number of "unnatural deaths" and number of "victims," which may refer to any type of political persecution from expulsion to public beatings. Because the county annals were encouraged but not required to publish any figures about Cultural Revolution violence, assumptions need to be made to deal with missing information. We first follow Walder (2014) and code missing values as 0 even if the narrative does refer to casualties but without stating a figure. Alternatively, we replace missing values by (i) the provincial average, (ii) the maximum in the province and (iii) the minimum in the province. Appendix Table A5, Panel F, uses the casualty data to condition for Cultural Revolution violence, distinguishing between "deaths" and "victims." Including these controls does not alter the results; the disruption created by the Cultural Revolution does not explain the decline of treated counties.

Economic reforms The transition from central planning to a more market-oriented economy may have dealt a severe blow to the state-owned "156" plants.

The Million-Rouble plants weathered the economic regime change quite well. Only 15 plants closed down, and the decline of treated counties between 1982 and 2010 is not due to Million-Rouble plants going bust (see Appendix Table A5). About a third of the "156" plants evolved into large, diversified industrial groups (jituan). One such jituan is Ansteel, which evolved from the Anshan Iron and Steel Company and is now listed on the Shenzhen and Hong Kong Stock Exchanges. Figure B2 displays a picture of the main plant in 2016 .

We further rely on the NBS above-scale survey (1992-2008) to shed light on the evolution of the Million-Rouble plants - see Appendix F for a description of the procedure followed to match plants with firms and a comparison of the MillionRouble plants with other firms in the same county. We find that (i) most plants are still active today (94 of the 125 Million-Rouble plants that operated in the manufacturing sector could be identified) and (ii) they are on average four times as productive as other above-scale firms (controlling for size; see Table F1 and the 
Figure B2. Entrance of the main Ansteel group plant in 2016.

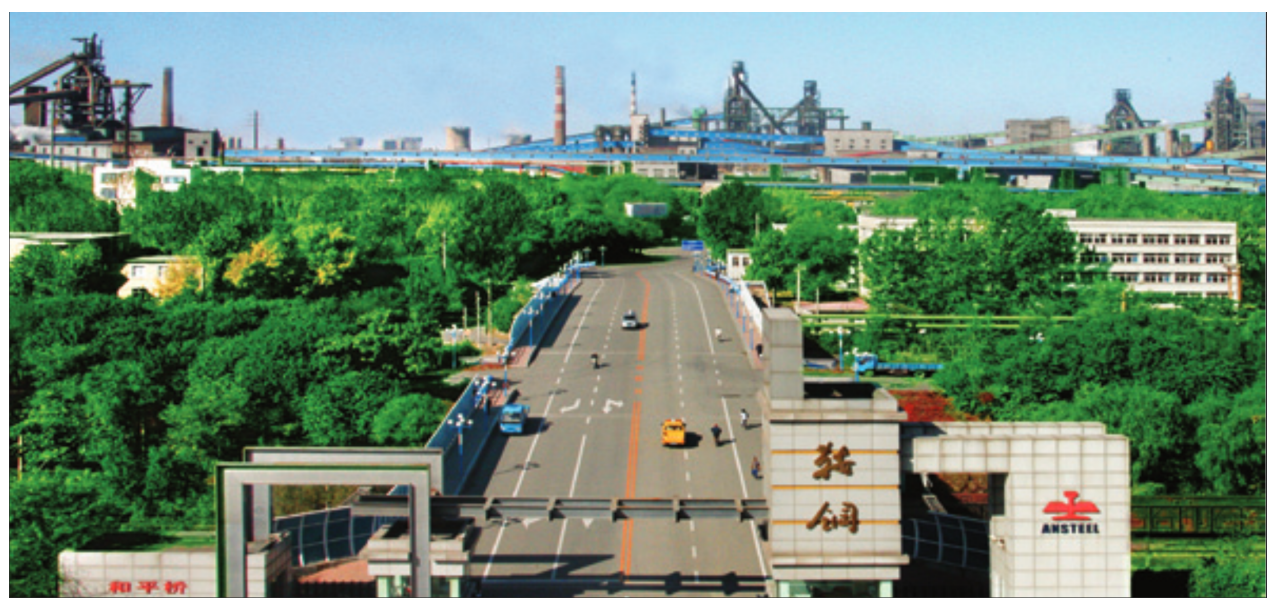

Source: Ansteel Group Corporation (2016).

detailed discussion in Appendix F).

Another major feature of China's development since the 1980s is the creation of Special Economic Zones and various types of industrial parks. These may have attracted production factors because of the promise of superior returns despite treated counties being productive and still growing. To test for this factor, we use industrial parks data from Zheng et al. (2009). The data are at the prefecture level and provide us with the number of industrial parks extant in a prefecture at some point in five-year intervals, covering the period 1980-2005. Appendix Table A5 controls for the total number of industrial parks in the prefecture and shows that the results are robust to this place-based policy. 


\section{Vulnerability to air strikes}

We construct measures of vulnerability to enemy bombings as follows: (i) we define a set of enemy airbases (the threat) and a set of allied airbases (the shield), (ii) we model the protection afforded by allied airbases against aerial attacks, (iii) we show how the distribution of airbases, combined with the previous parameterization of flying costs, generate a vulnerability map across Chinese counties.

This paper uses two main measures of vulnerability to enemy bombings: (a) at the beginning of the "156" program, as a source of exogenous variation in the locations of the Million-Rouble plants, and (b) after the Sino-Soviet Split as a control for later industrial investments.

\section{C.1 Allied and enemy airbases over time}

In this section, we describe and map the distribution of enemy air allied airbases over time.

When the "156" program was being designed, China benefited from the 1950 Treaty of Friendship, Alliance and Mutual Assistance. Not only were the U.S.S.R. and North Korea friendly neighbors; China could count on their protection in case of American or Taiwanese aggression, as stipulated by the Treaty.

However, we also need to compute measures of vulnerability in later periods. Indeed, vulnerability to U.S. and Taiwanese air strikes at the beginning of the " 156 " program may be correlated with vulnerability in later periods, which may have motivated spatial policies that affected our outcomes of interest. After the SinoSoviet split, China no longer enjoyed protection from Soviet and North Korean airbases against American or Taiwanese attacks. These formerly allied airbases now presented a threat. To reflect this new geopolitical situation, we consider not only former American and Taiwanese bases, but also Soviet and North Korean airbases as threats in addition to American airbases that were opened in Vietnam between the beginning of the " 156 " program and the onset of the Third Front Movement.

We display the distribution of enemy and allied airbases over time in Appendix Figure C1. We also display the surveillance flights from U.S. reconnaissance airflights, as provided by declassified CIA technical intelligence studies. Even though U.S.S.R. airbases are not protecting the territory of China anymore, their presence affects the paths of these flights and the crescent formed by the Second Front of MRPs is far less visited than coastal areas. In the next section, we calibrate a simple model of travel cost to account for the role of allied airbases in shielding some locations in China against aerial attacks. 
Figure C1. Distribution of enemy and allied airbases.

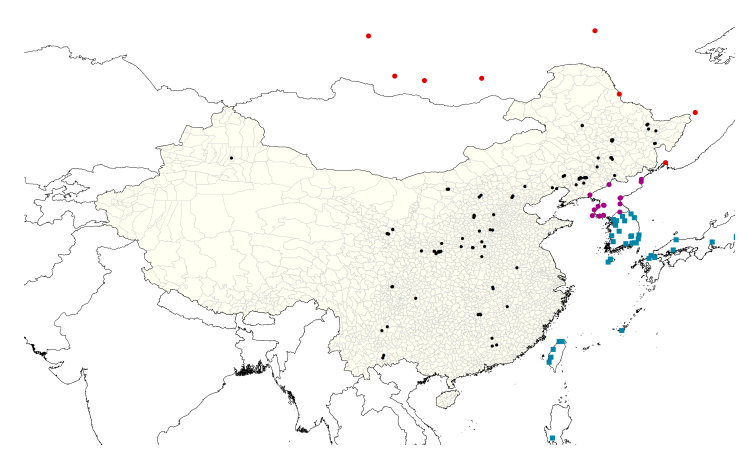

(a) Pre-1960 split

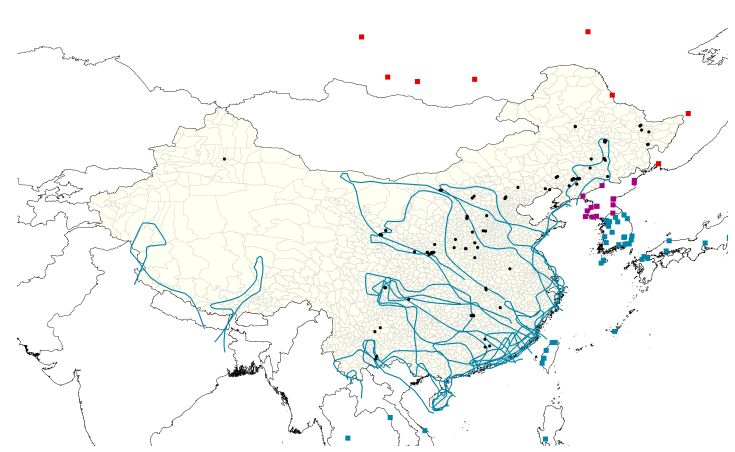

(b) Post-1960 split

Notes: This map shows the distribution of enemy and allied air bases in 1953 and in 1964. U.S. airbases are indicated with a green rectangle; North Korean airbases are indicated with a purple circle/rectangle; Soviet airbases are indicated with a red circle/rectangle. In the right panel, we add the paths of surveillance flights between 1963 and 1965. The locations of MRPs are indicated with a dark circle.

\section{C.2 Flying cost and penalty}

Flying cost We assume a constant default flying cost over the Chinese territory and model allied airbases protection as an additional cost for enemy bombers. This penalty is defined as follows:

$$
f\left(d, d^{\prime}\right)=\alpha\left(1-e^{-g d^{\prime}}\right) \cdot \frac{e^{a(\bar{x}-d)}-e^{-b(\bar{x}-d)}}{e^{a(\bar{x}-d))}+e^{-b(\bar{x}-d))}}+C,
$$

where $d$ is distance to the closest allied airbase and $d^{\prime}$ is distance to enemy airbases, in kilometers. The parameter $\alpha$ calibrates the maximum penalty in the immediate neighborhood of allied bases. The dependence of the penalty to distance to allied bases is modeled as a hyperbolic tangent: The penalty vanishes as distance $d$ goes to infinity, increases as $d$ decreases, and reaches a plateau near the airbase. The parameter $a(b)$ disciplines the curvature of the hyperbolic tangent function for low (high) values of $d$. The inflection points are tied to the value of $\bar{x}$. Finally, the dependence of the penalty to distance to enemy bases is disciplined by $g$. This parameter determines how the cost paid by enemy bombers for traveling near allied bases is mitigated by the proximity to their own bases.

Parameterization We set the key parameters based on declassified CIA technical intelligence documents from the early 1950s. Such documents show the information available to U.S. intelligence on Soviet military technology, obtained from spies and through the reverse-engineering of fighter jets downed during the Korean War. We assume perfect information: the Soviet similarly derived information about U.S. 
military technology, and expected the Americans to know theirs equally well. In keeping with the 1950 Treaty, Soviet military advisers shared their information with their Chinese counterparts, in particular to determine the location of the MillionRouble plants.

American bombers in the 1950s, like the B-52s, could technically reach any point in China without refueling. However, bombers could be neutralized by interceptors, stationed in allied airbases. Declassified CIA documents such as the one reproduced in Appendix Figure C2 provide us with information on the ranges of the main Soviet interceptor (used both in North Korea and the USSR), the MiG-15, and the main American jet fighter at the time, the F-86 Sabre. We use the maximum range of the interceptors under "military power" and we define $\bar{x}$ as half the maximum range of Soviet interceptors (840 nautical miles or 1,555.68 km- see the table in Figure C2) and determine $a$ and $b$ such that $95 \%$ of the decrease in flying cost occurs over that range. Similarly, $g$ is set so that $95 \%$ of the protection enjoyed by American bombers close to their bases occurs within the maximum range of the F-86 Sabre. Finally, $\alpha$ and $C$ are set equal and such that Chinese counties protected by Soviet and North Korean airbases are as safe as remote western counties.

Figure C2. Declassified CIA technical intelligence studies-MiG 15.

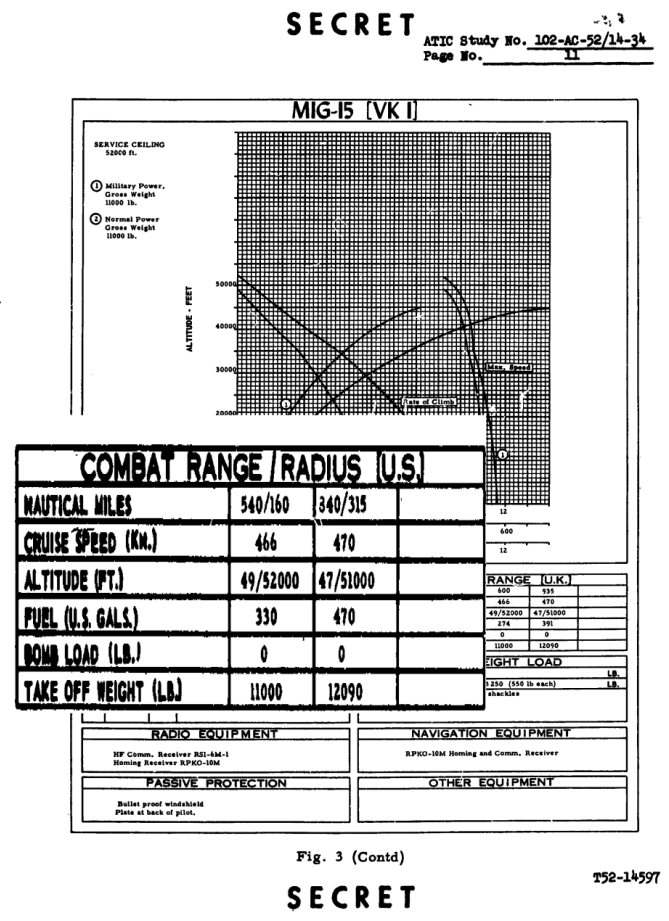

Sources: CIA technical intelligence study No. 102-AC-52/14-34, "Soviet Operational Interceptor Aircraft" (3 September 1952). 


\section{C.3 Vulnerability maps}

In this section, we briefly describe how the distribution of airbases, combined with the previous parameterization of flying costs, translate into vulnerability maps across Chinese counties.

As shown in Figure 4 (Panel a), vulnerability to aerial attacks in 1953 favors Northern provinces. This vulnerability, combined with the existing transportation network and coal deposits, draws a crescent from Harbin (North-East) to Xi'an (Shaanxi province). Most MRPs can be found along this crescent, which forms a "Second Front" in the connected hinterlands. Few MRPs are located in Central China, in spite of the high risk of aerial attacks. These few factories however rely on very specific input, e.g., minerals, which can only be found in high-risk locations.

In Panel b of Figure 4, we display vulnerability to aerial attacks in 1964 after U.S.S.R. airbases become enemy threats. The set of suitable and protected locations then becomes small as all counties related to the transportation network are then in the range of enemy bombers. We see, in particular, that some areas that were protected by the Soviet and North Korean allies, such as the northeast and to a lesser extent counties bordering Mongolia, are now extremely vulnerable. Central provinces, removed from both U.S./Taiwanese and Soviet bombing threats, are now the safest. This new vulnerability map rationalizes the Third Front Movement, targeted towards interior, remote provinces (see Fan and Zou, 2019). 


\section{Data description}

In this section, we describe the construction of measures of factor productivity at the establishment level, identified using industry-specific CES production functions and an exogenous labor supply shifter (Imbert et al., 2018), patents linked to establishments (He et al., 2018), and markups De Loecker and Warzynski (2012).

\section{D.1 Measures of factor productivity}

The measures of factor productivity used in Section 4 are taken from Imbert et al. (2018). The following discussion briefly describes the production model and its identification; the reader can refer to Imbert et al. (2018) for details of the implemented strategy.

Environment Consider establishments producing a differentiated variety of good using a CES production function with only two factors, labor and capital.

Let $Y$ and $P$ (resp. $y_{i}$ and $p_{i}$ ) denote the aggregate output and prices within a product market (resp. for establishment $i$ ). We assume that there is monopolistic competition such that demand for the product variety $i$ is,

$$
\frac{y_{i}}{Y}=\left(\frac{p_{i}}{P}\right)^{-\sigma}
$$

where $\sigma$ captures the substitutability between product varieties. An establishment $i$ produces along,

$$
y_{i}=A_{i}\left[\alpha k_{i}^{\rho}+\beta l_{i}^{\rho}\right]^{\frac{1}{\rho}},
$$

where $(\alpha, \beta=1-\alpha, \rho)$ capture factor intensities and factor complementarity. Wages and returns to capital are taken as given.

Estimation There are three important parameters, $(\sigma, \alpha, \rho)$, which characterize production at the sector level. These parameters can be identified - at the sector level - as follows: (i) a factor cost shifter helps identify the degree of substitutability between factors $(\rho)$, (ii) given the estimate for $\rho, \alpha$ and $\sigma$ can be retrieved through the observation of aggregate factor shares and profits to revenues within a sector.

We briefly describe the first, crucial step of this procedure. Firm-specific relative factor demand verifies: ${ }^{50}$

$$
\ln \left(k_{i} / l_{i}\right)=\frac{1}{1-\rho} \ln \left(\frac{\alpha}{1-\alpha}\right)+\frac{1}{1-\rho} \ln (w / r)+\varepsilon_{i},
$$

\footnotetext{
${ }^{50}$ One can combine the two first-order conditions of the firm, and show that the optimal factor
} 
where $\varepsilon_{i}$ is a noise, possibly capturing measurement error or firm-specific technology. The parameter $\rho$ can be identified, in the previous equation, by leveraging exogenous variation in relative factor prices across prefectures and across years in order to instrument the relative factor price. Imbert et al. (2018) rely on predicted immigration shocks, constructed from cropping patterns in rural hinterlands. These shocks are exogenous to factor demand in cities, including demand resulting from the presence of MRPs.

Once $(\sigma, \alpha, \rho)$ are estimated, the main firm-specific measure of productivity used in this paper, Total factor Productivity, is constructed using:

$$
A_{i}=\frac{y_{i}}{\left[\hat{\alpha} k_{i}^{\hat{\rho}}+(1-\hat{\alpha}) l_{i}^{\hat{\rho}}\right]^{\frac{1}{\hat{\rho}}}} .
$$

\section{D.2 Registered patents}

The measures of patenting used in Section 4 exploit the bridge constructed by $\mathrm{He}$ et al. (2018) to match firms with all patents submitted to the State Intellectual Property Office (SIPO).

There are three categories of patents submitted to SIPO. A patent can be categorized as "design"; this category mostly covers the external appearance of a product. A patent can be categorized as "innovation"; this category covers fundamental innovations either regarding the final product or the means of production. These patents offer significant protection but require to go through a long administrative process. A patent can be categorized as "utility" (utility model patent); this category covers changes in processing, shape or structure of products. The latter category has no equivalent outside of China; it often acts as a cheap, fast way to protect an ideapossibly with the objective of registering an innovation patent in the longer run. For these reasons, we construct our main "patent" variable as the number of utility and innovation patents registered by establishments in a given county and year.

\section{D.3 Measures of markups}

Environment We measure markups at the firm level using the strategy developed in De Loecker and Warzynski (2012). Intuitively, the markup can be estimated by use verifies:

$$
\left\{\begin{array}{c}
(1-1 / \sigma) \frac{\alpha k_{i}^{\rho}}{\alpha k_{i}^{\rho}+\beta l_{i}^{\rho}} p_{i} y_{i}=r k_{i} \\
(1-1 / \sigma) \frac{\beta l_{i}^{\rho}}{\alpha k_{i}^{\rho}+\beta l_{i}^{\rho}} p_{i} y_{i}=w l_{i}
\end{array}\right.
$$


comparing the growth of a certain production input to the subsequent growth in output.

Consider an establishment $i$ at time $t$. The establishment uses the following production technology:

$$
y=f\left(x_{1}, \ldots, x_{N}, k, A\right)
$$

where $\left\{x_{1}, \ldots, x_{N}\right\}$ are variable inputs, $k$ is a dynamic input (i.e., capital) and $A$ is a scalar Hicks-neutral (Total Factor) productivity term. The first-order conditions bring:

$$
\varepsilon_{i}=\frac{\partial f\left(x_{1}, \ldots, x_{N}, k, A\right)}{\partial x_{i}} \frac{x_{i}}{y}=\frac{p}{\lambda} \frac{p_{i} x_{i}}{p y},
$$

where $\varepsilon_{i}$ is the output elasticity to variable input $i$ and $\mu=\frac{p}{\lambda}$ is the markup. Consequently,

$$
\mu=\varepsilon_{i} / \alpha_{i}
$$

where $\alpha_{i}=\frac{p_{i} x_{i}}{p y}$ is the share of expenditures on the variable input $i$.

Estimation We estimate the output elasticity to variable input $i$, using a control approach. This approach requires two assumptions on function $f$ : (i) the parameter $A$ enters as a multiplicative term, (ii) there is a common set of technology parameters across producers.

The estimation is described in De Loecker and Warzynski (2012), and proceeds in two steps. In a first step, we estimate output as a flexible function of inputs (labor, capital and material). The residual of this estimation maps into the productivity term $A$. In a second step, we estimate the law of motion for productivity over time.

This procedure allows us to estimate the output elasticity to variable input $i$, which we transform into a markup by combining it with an estimate $\hat{\alpha}$ for the expenditure share $\alpha$. This last correction replaces the output by the predicted output thereby cleaning for measurement error in the denominator of the expression for $\mu$. 


\section{E Additional outcomes, robustness checks and sensitivity analysis}

In this section, we first provide a comprehensive analysis of factor use, factor productivity, firm characteristics, patenting behavior, investment and subsidies in the average establishment. We then provide a set of robustness checks around the main results of Section 4.

\section{E.1 Detailed treatment effects on the structure of production}

We report in Table E1 the average treatment effect on factor productivity (Panel A), firm type and characteristics of the workforce (Panel B), cashflows, subsidies and investment (Panel C), factor intensity (Panel D), patenting (Panel E) and markups (Panel F).

Factor productivity The first and last columns of Panel A are already discussed in the main text. In addition, we find that labor productivity is lower in treated counties and consistent with the drop in labor cost (Table E1, column 2), capital productivity and TFP are 37 and $30 \%$ lower than in control counties.

Firm characteristics Next, we characterize the establishment "type" in treated counties, specifically whether the average establishment is more likely to be publicly owned, older and biased towards a more educated and experienced workforce. Panel B of Table E1 shows that manufacturing establishments are 11 percentage points more likely to be publicly-owned, and more likely to be older than three years; these effects are however small. The composition of the workforce markedly differs between treated and control counties: the average employee in treated counties is much more likely to be a skilled worker, and 11 percentage points more likely to occupy a "senior" position within the firm (to be compared with the 28 percentage points share of senior workers). In view of this observation, our finding that wages are lower in treated counties is puzzling, and this finding is inconsistent with an explanation based on under-investment in human capital (Franck and Galor, 2017).

Financing structure We describe the financing structure of establishments in treated counties, their investment, and the expenditures devoted to R\&D in Panel C. The patterns from this analysis do not support a story based on political favoritism (Chen et al., 2017; Fang et al., 2018): public subsidies appear to be non-significantly higher in treated counties (see column 1). The results are inconsistent with a privileged access to resources (Harrison et al., 2019): total liabilities are not higher than 
in control counties (column 2). Short-term investment is lower but not very strongly so (see column 3). The financing structure in the average (other) establishment in treated counties appear to be quite similar to that of control counties.

Factor intensities We characterize production in treated counties using product codes at the 4-digit level (Panel D). We regress the (log) factor intensity, as predicted by the 4-digit product code (following the classification of Shirotori et al., 2010), on the treatment $T_{c}$, instrumented by $V_{c}$. In this specification, we omit year interacted with 4-digit industry fixed-effects and only include year-fixed effects. The average product in treated counties is $6 \%$ more human-capital-intensive, $19 \%$ more physicalcapital-intensive and $4 \%$ more land-intensive. These findings point toward some specialization of treated counties in capital-intensive production, but the extent of such specialization remains moderate.

Innovation and patenting We now turn to the more direct analysis of technological innovation through the analysis of patent applications across establishments (Panel E). We distinguish three categories: design (minor changes in design), innovation and utility, the latter categories being the most relevant to capture technological progress. We find that establishments in treated counties produce fewer patents: 0.031 (design), -.024 (invention) and -.023 (utility, used in the baseline), -.062 (all). These effects are of the order of magnitude of the yearly number of patents produced in the average establishment: there are very few patents that are registered in treated counties.

Markups We now turn to the analysis of markups across establishments. We rely on a translog specification for the production function and consider two main strategies: A (without inputs in the control function), B (using direct materials as input in the control function). For both strategies, we construct two measures for markups: a dummy equal to one if the markup is above-median within a 4-digit industry $\times$ year cell and the (log) markup. As shown in Panel F, markups are slightly higher in treated counties.

Entry, exit and dispersion Factor cost and factor productivity appear to be low in treated counties, but dispersed. In Panel A of Appendix Table E2, we calculate the standard deviation in labor cost within county $\times$ year (weighted by firm employment), and regress the measure of wage dispersion on the treatment $T_{c}$, instrumented by $V_{c}$. We find a higher dispersion of about $14 \%$ in treated counties (Table E2, column 1). In columns 2, 3 and 4 of Appendix Table E2, we replicate 
the previous exercise with the standard deviations of productivity measures as dependent variables. Measures of labor productivity are more dispersed within treated counties than within control counties. The dispersion in labor cost and productivity indicates frictions in the allocation of resources across establishments. In Panel B of Appendix Table E2, we show that there is a higher concentration of production in large establishments of treated counties. In Panel $\mathrm{C}$ of Appendix Table E2, we show that there is no higher likelihood of exit in treated counties; this observation also holds for establishments not along the production chain of the local $\operatorname{MRP}(\mathrm{s})$.

\section{E.2 Sensitivity analysis}

In this section, we implement a set of robustness checks in order to discard competing explanations for the main findings of Section 4. These competing channels are: the demise of publicly-owned firms between 1992 and 2008 - are they predominantly in treated counties, and along the production chain of MRPs?-, the misallocation of (public) resources - are they targeting unproductive firms in treated counties, and particularly so along the production chain of MRPs?-, lower dynamism related to the life-cycle of establishments - are they older in treated counties, and particularly so along the production chain of MRPs?

Empirical strategy In order to provide evidence for these possible compositional effects, we implement three main empirical strategies. The first strategy cleans for possible compositional effects in the baseline specification, i.e.,

$$
Y_{i t}=\beta_{0}+\beta_{1} T_{c}+\beta_{2} T_{c} \times S_{i t}+\beta_{\mathbf{x}} \mathbf{X}_{c}+\eta_{r t}+\nu_{s t}+\varepsilon_{i s c t}
$$

where $\eta_{r t}$ is a set of time $\times$ firm-type $(r)$ fixed effects.

The second strategy analyzes the prevalence of public, subsidized, young firms along the production chain of $\operatorname{MRP}(\mathrm{s})$ by running the baseline specification with respective dummies as dependent variables (and no fixed effects for the different firm types).

The third strategy controls for the possible heterogeneous treatment effects on firms of different types,

$$
Y_{i t}=\beta_{0}+\beta_{1} T_{c}+\beta_{2} T_{c} \times S_{i t}+\beta_{3} T_{c} \times \mathbb{1}_{R_{i t}=r}+\beta_{\mathbf{x}} \mathbf{X}_{c}+\eta_{r t}+\nu_{s t}+\varepsilon_{i s c t}
$$

where $\mathbb{1}_{R_{i t}=r}$ is a dummy equal to 1 if firm $i$ is of type $r$.

Using these strategies, we provide below a comprehensive analysis of compositional effects, i.e., we analyze how differences in production structure may reflect 
differences in the industrial fabric, differences in the ownership structure or the presence of establishments at different stages of their life cycle.

Compositional analysis The previous strategies provide the following insights:

- Controlling for the presence/absence of public, subsidized, young firms in treated counties does not change the baseline findings. Treated establishments are less productive, less innovative and less competitive (Appendix Table E3).

- Firms which are downstream/upstream of MRP(s) are not very different from the average establishment in treated counties: they are slightly more likely to be public and younger but none of these effects are really large (Panel A, Appendix Table E4). Establishments in the same product market as MRPs are however much older and much more likey to be publicly-owned (Panel B, Appendix Table E4).

- The previous compositional effects cannot however explain the main findings of Section 4: public establishments in treated counties are indeed relatively productive and innovative compared to their counterparts in control counties (Panel A, Appendix Table E5). 
Table E1. Structure of firm production (average treatment effect).

\begin{tabular}{lcccc}
\hline VARIABLES & Labor cost & MPL & MPK & TFP \\
& $(1)$ & $(2)$ & $(3)$ & $(4)$ \\
\hline \multicolumn{2}{c}{ Panel A: factor productivity } & & & \\
Treatment & -.320 & -.217 & -.368 & -.304 \\
& $(.078)$ & $(.121)$ & $(.117)$ & $(.104)$ \\
Observations & 432,202 & 432,202 & 432,202 & 432,202 \\
\hline VARIABLES & Public & Young & Emp. (skilled) & Emp. (senior)
\end{tabular}

(1) $\quad(2)$

Panel B: firm characteristics (public ownership, unions, employment structure)

\begin{tabular}{lcccc} 
Treatment & .110 & -.074 & .178 & .094 \\
& $(.029)$ & $(.036)$ & $(.031)$ & $(.027)$ \\
Observations & 432,202 & 432,202 & 22,691 & 22,691 \\
\hline VARIABLES & Subsidies & Cash inflow (fin.) & Investment ST & R\&D expenses \\
& $(1)$ & $(2)$ & $(3)$ & $(4)$
\end{tabular}

Panel C: Financing, Investment, R\&D and technology

\begin{tabular}{lcccc} 
Treatment & -.016 & .030 & -.016 & -.001 \\
& $(.034)$ & $(.029)$ & $(.010)$ & $(.015)$ \\
Observations & 281,778 & 281,778 & 215,142 & 215,142 \\
\hline
\end{tabular}

\begin{tabular}{|c|c|c|c|}
\hline VARIABLES & $\begin{array}{l}\text { Human capital } \\
\text { (1) }\end{array}$ & $\begin{array}{c}\text { Physical capital } \\
(2)\end{array}$ & $\begin{array}{l}\text { Land } \\
(3)\end{array}$ \\
\hline
\end{tabular}

$\begin{array}{cccc}\text { Treatment } & .063 & .194 & .042 \\ & (.017) & (.047) & (.029)\end{array}$

\begin{tabular}{ccccc} 
Observations & 402,785 & 402,785 & 402,785 & \\
\hline VARIABLES & Design & Utility & Invention & All \\
& $(1)$ & $(2)$ & $(3)$ & $(4)$ \\
\hline Panel E: Patents & & & &
\end{tabular}

\begin{tabular}{|c|c|c|c|c|}
\hline Treatment & $\begin{array}{l}-.031 \\
(.014)\end{array}$ & $\begin{array}{l}-.023 \\
(.008)\end{array}$ & $\begin{array}{l}-.024 \\
(.014)\end{array}$ & $\begin{array}{l}-.062 \\
(022)\end{array}$ \\
\hline
\end{tabular}

\begin{tabular}{|c|c|c|c|c|}
\hline Observations & 432,202 & 432,202 & 432,202 & 432,202 \\
\hline VARIABLES & $\underset{(1)}{\operatorname{Markup}(\mathrm{A}, \mathrm{m})}$ & Markup $(\mathrm{A}, \mathrm{l})$ & Markup $(\mathrm{B}, \mathrm{m})$ & Markup $(B, 1)$ \\
\hline \multicolumn{5}{|c|}{ Panel F: Markups } \\
\hline Treatment & $\begin{array}{c}.130 \\
(.062)\end{array}$ & $\begin{array}{c}.086 \\
(.042)\end{array}$ & $\begin{array}{c}.075 \\
(.062)\end{array}$ & $\begin{array}{c}.070 \\
(.049)\end{array}$ \\
\hline Observations & 301,198 & 207,355 & 173,382 & 120,203 \\
\hline
\end{tabular}

Notes: Standard errors are clustered at level of 4-degree $\times$ 4-degree cells. All specifications include the baseline controls (Table 4), 4-digit industry $\times$ year fixed effects, except in Panel D, and firm type $\times$ year fixed effects, except in Panel B. Labor cost is the logarithm of total compensation per employee; MPL (resp. MPK, TFP) is the logarithm of firm-specific labor productivity (resp. capital, total factor productivity) as computed in Imbert et al. (2018). Public and Young are dummies equal to 1 if the firm is a state-owned enterprise, and is younger than 3 years. All variables of Panel $\mathrm{C}$ are dummies equal to 1 if the associated accounting variable is positive. Factor intensities are the (log) factor intensity, as predicted by the 4-digit product code (following the classification of Shirotori et al., 2010). Markup (m) (resp. l) is a dummy equal to one if the markup is above-median within a 4-digit industry $\times$ year cell (resp. the log. markup), computed following De Loecker and Warzynski (2012)—see Appendix D. 
Table E2. Sensitivity analysis - dispersion, concentration and entry/exit at the county-level.

\begin{tabular}{|c|c|c|c|c|}
\hline$\overline{\text { VARIABLES }}$ & $\begin{array}{c}\text { Labor cost } \\
\text { (1) }\end{array}$ & $\begin{array}{c}\text { MPL } \\
(2)\end{array}$ & $\begin{array}{c}\text { MPK } \\
(3)\end{array}$ & $\begin{array}{l}\text { TFP } \\
(4)\end{array}$ \\
\hline Treatment & $\begin{array}{l}.137 \\
(.050)\end{array}$ & $\begin{array}{l}.160 \\
(.103)\end{array}$ & $\begin{array}{l}-.024 \\
(.120)\end{array}$ & $\begin{array}{l}.041 \\
(.103)\end{array}$ \\
\hline Observations & 2,786 & 2,462 & 2,462 & 2,462 \\
\hline VARIABLES & $\begin{array}{r}\text { Her } \\
\text { Employment } \\
(1)\end{array}$ & $\begin{array}{c}\text { Output } \\
(2)\end{array}$ & $\begin{array}{l}\text { Larg } \\
\text { Employment } \\
(3)\end{array}$ & $\begin{array}{l}\text { Output } \\
\text { (4) }\end{array}$ \\
\hline \multicolumn{5}{|c|}{ Panel B: Concentration in employment and output } \\
\hline Treatment & $\begin{array}{l}.018 \\
(.036)\end{array}$ & $\begin{array}{l}.054 \\
(.045)\end{array}$ & $\begin{array}{l}.283 \\
(.097)\end{array}$ & $\begin{array}{l}.212 \\
(.090)\end{array}$ \\
\hline Observations & 3,729 & 3,729 & 3,729 & 3,042 \\
\hline VARIABLES & $\begin{array}{l}\text { Number } \\
\text { All } \\
(1)\end{array}$ & $\begin{array}{l}\text { ants } \\
\text { Outside } \\
\quad(2)\end{array}$ & $\begin{array}{l}\text { Number } \\
\text { All } \\
(3)\end{array}$ & $\begin{array}{l}\text { Outside } \\
\text { (4) }\end{array}$ \\
\hline \multicolumn{5}{|c|}{ Panel C: Entry \& exit } \\
\hline Treatment & $\begin{array}{l}-.010 \\
(.014)\end{array}$ & $\begin{array}{l}-.011 \\
(.030)\end{array}$ & $\begin{array}{l}.015 \\
(.020)\end{array}$ & $\begin{array}{l}.034 \\
(.041)\end{array}$ \\
\hline Observations & 3,729 & 3,729 & 3,729 & 3,729 \\
\hline
\end{tabular}

Table E3. Sensitivity to additional controls (public, subsidized, young).

\begin{tabular}{lccc}
\hline VARIABLES & TFP & Patents \\
& $(1)$ & $(2)$ & $\begin{array}{c}\text { Markup } \\
(3)\end{array}$ \\
\hline Treatment & -.288 & -.024 & .135 \\
& $(.104)$ & $(.008)$ & $(.062)$ \\
Observations & 392,829 & & \\
\hline \hline
\end{tabular}

Notes: Standard errors are clustered at level of 4-degree $\times 4$-degree cells. The unit of observation is a firm $\times$ year. We exclude the MRPs from the sample. All specifications include the baseline controls (Table 4), 4-digit industry $\times$ year fixed effects and firm type $\times$ year fixed effects. Labor is the logarithm of the number of workers; Capital is the logarithm of real capital; Labor cost is the logarithm of total compensation per employee; TFP is the logarithm of firm-specific total factor productivity as computed in Imbert et al. (2018); Patents are the number of patent applications registered by the firm; Markup is a dummy equal to one if the markup is above-median within a 4-digit industry $\times$ year cell, computed following De Loecker and Warzynski (2012)—see Appendix D. 
Table E4. Characteristics of establishments along the production chain of MRPs.

\begin{tabular}{|c|c|c|c|}
\hline VARIABLES & $\begin{array}{c}\text { Public } \\
(1)\end{array}$ & $\begin{array}{c}\text { Subsidized } \\
(2)\end{array}$ & $\begin{array}{c}\text { Young } \\
(3)\end{array}$ \\
\hline \multicolumn{4}{|c|}{ Panel A: Downstream/Upstream } \\
\hline \multirow[t]{2}{*}{ Treatment } & .104 & -.010 & -.073 \\
\hline & $(.030)$ & $(.028)$ & $(.036)$ \\
\hline \multirow[t]{2}{*}{ Treatment $\times$ Linkage } & .084 & -.024 & .035 \\
\hline & $(.065)$ & $(.075)$ & $(.060)$ \\
\hline Observations & 432,202 & 392,829 & 432,202 \\
\hline \multicolumn{4}{|l|}{ Panel B: Same product } \\
\hline \multirow[t]{2}{*}{ Treatment } & .103 & -.008 & -.068 \\
\hline & $(.030)$ & $(.028)$ & $(.035)$ \\
\hline \multirow[t]{2}{*}{ Treatment $\times$ Same product } & .339 & -.154 & -.292 \\
\hline & $(.142)$ & $(.135)$ & $(.114)$ \\
\hline Observations & 432,202 & 392,829 & 432,202 \\
\hline
\end{tabular}


Table E5. Sensitivity analysis - compositional effects (public, subsidized, young).

\begin{tabular}{|c|c|c|c|}
\hline VARIABLES & $\begin{array}{c}\text { TFP } \\
(1)\end{array}$ & $\begin{array}{c}\text { Patents } \\
(2)\end{array}$ & $\begin{array}{c}\text { Markup } \\
(3)\end{array}$ \\
\hline \multicolumn{4}{|l|}{ Panel A: Public } \\
\hline Treatment & $\begin{array}{l}-.401 \\
(.123)\end{array}$ & $\begin{array}{l}-.045 \\
(.019)\end{array}$ & $\begin{array}{c}.135 \\
(.070)\end{array}$ \\
\hline Treatment $\times$ Public & $\begin{array}{c}.439 \\
(.251)\end{array}$ & $\begin{array}{c}.061 \\
(.034)\end{array}$ & $\begin{array}{l}-.026 \\
(.070)\end{array}$ \\
\hline Observations & 432,202 & 432,202 & 301,198 \\
\hline \multicolumn{4}{|l|}{ Panel B: Subsidized } \\
\hline Treatment & $\begin{array}{l}-.295 \\
(.109)\end{array}$ & $\begin{array}{c}-.026 \\
(.016)\end{array}$ & $\begin{array}{c}.154 \\
(.069)\end{array}$ \\
\hline Treatment $\times$ Subsidized & $\begin{array}{c}.042 \\
(.091)\end{array}$ & $\begin{array}{l}-.010 \\
(.045)\end{array}$ & $\begin{array}{l}-.104 \\
(.054)\end{array}$ \\
\hline Observations & 392,829 & 392,829 & 273,013 \\
\hline \multicolumn{4}{|l|}{ Panel C: Young } \\
\hline Treatment & $\begin{array}{c}-.256 \\
(.110)\end{array}$ & $\begin{array}{c}-.037 \\
(.017)\end{array}$ & $\begin{array}{c}.143 \\
(.060)\end{array}$ \\
\hline Treatment $\times$ Young & $\begin{array}{l}-.133 \\
(.120)\end{array}$ & $\begin{array}{c}.012 \\
(.024)\end{array}$ & $\begin{array}{l}-.048 \\
(.051)\end{array}$ \\
\hline Observations & 432,202 & 432,202 & 301,198 \\
\hline
\end{tabular}

Notes: Standard errors are clustered at level of 4-degree $\times$ 4-degree cells. The unit of observation is a firm $\times$ year. We exclude the MRPs from the sample. All specifications include the baseline controls (Table 4), 4-digit industry $\times$ year fixed effects and firm type $\times$ year fixed effects. Downstream/Upstream is a dummy equal to one if the firm is down (or up) the supply chain with respect to one of the 156 factories; Same product is a dummy equal to one if the firm is in the same product market as one of the 156 factories 


\section{F Firm comparison within treated places}

The rise-and-fall pattern experienced by treated counties could potentially reflect the experience of the Million-Rouble plants themselves. Local economies may have thrived following the physical capital investments of the "156" program and then declined as this capital depreciated. Such a co-evolution of the Million-Rouble plants and local economies may have obtained because of (i) the sheer size of the " 156 " plants in the local economies and (ii) spillover effects.

In this Appendix, we investigate the evolution of the Million-Rouble plants and whether they might have dragged other firms down. To this end, we identify the "legal units" (faren danwei) descended from the Million-Rouble plants in the annual firm survey data described in Section 2. We develop a fuzzy matching algorithm based on firm names, locations and creation dates, and check manually the quality of the results. We can match 94 or $75 \%$ of the 125 Million-Rouble plants that operated in the manufacturing sector

Size in the local economy Table F1 relies on the identification of the MillionRouble plants in the "above-scale" firms to compute the share of the Million-Rouble plants in the economies of treated counties. Over the period 1992-2008, MillionRouble plants accounted for a moderate share of the economic activity in treated counties: they represent $2.6 \%$ of manufacturing employment, $4.3 \%$ of the total wage bill in that sector, $6.0 \%$ of revenue, $4.4 \%$ of value added and $2.8 \%$ of profits. $^{51}$

Table F1. Share of the "156" factories in local economies.

\begin{tabular}{lccccc}
\hline & Employment & Compensation & Revenue & Value added & Profits \\
& $(1)$ & $(2)$ & $(3)$ & $(4)$ & $(5)$ \\
\hline Share & 0.026 & 0.043 & 0.060 & 0.044 & 0.028 \\
& $(0.169)$ & $(0.273)$ & $(0.378)$ & $(0.304)$ & $(1.654)$ \\
Observations & 938 & 938 & 938 & 938 & 938 \\
\hline \hline
\end{tabular}

Notes: Standard deviations are reported between parentheses. The sample consists of all treated counties where at least one firm in the NBS annual "above-scale" surveys was identified as descended from one of the " 156 " factories. It covers the period 1998-2007, for which the dependent variables are available. For each variable, the table displays the share of such factories, e.g., Employment is the share of those factories in local manufacturing employment (1992-2008). Revenue refers to total sales. It is available in 1996-2007, except for 1997. Compensation (19962008, except for 1997) combines wages, housing subsidies, pension and medical insurance, and welfare payable. Value added is available between 1998 and 2007, 2004 excluded. Profits are defined as value added minus total compensation. They are available from 1998 to 2007, except for 2004. The unit of observation is a prefecture $\times$ year $\times$ industry (2-digit, Chinese Industrial Classification).

\footnotetext{
${ }^{51}$ Not all "156" factories have been matched to firms in the "above-scale" data. These figures are thus lower bounds.
} 
Productivity Table F2 compares the Million-Rouble plants with other firms within treated counties along various measures of productivity. As productivity may be systematically correlated with firm size, all regressions control for employment. We further include county, year and two-digit industry fixed effects in all specifications.

Establishments descended from the "156" plants differ significantly from other establishments of similar size, and these differences are economically large. First, they exhibit a much higher share of high-skill (i.e., college-educated) employees. ${ }^{52}$ This share is 12 percentage points higher in Million-Rouble plants, from an average of $22 \%$ among the other firms. Column 2 shows that compensation per worker is also (albeit not significantly) higher, which probably reflects the quality of the workforce. ${ }^{53}$ Second, value added per worker is four times higher. Third, we look at factor productivity measures developed by Imbert et al. (2018). These measures, based on industry-specific CES production functions identified using an exogenous labor supply shifter, show a large and consistent productivity differential. The Million-Rouble plants are three to four times as productive as other firms in treated counties in terms of the marginal product of labor, marginal product of capital and total factor productivity. Finally, a large literature (e.g., Song et al., 2011) highlights the lower productivity of state-owned enterprises during the transition in China. Column 7 looks at an indicator variable for public ownership. We find that the Million-Rouble plants do not significantly differ from the other firms in treated counties in terms of ownership.

\footnotetext{
${ }^{52}$ The disaggregation of the workforce by educational attainment is available only for 2004 (year of the Economic Census, when additional variables were collected).

${ }^{53}$ This result also holds when looking at wages. In addition to wages, compensation includes housing subsidies, pension and medical insurance, and welfare payable.
} 
Table F2. Comparison of MRPs and other manufacturing firms within treated prefectures.

\begin{tabular}{|c|c|c|c|c|c|c|c|}
\hline & $\begin{array}{l}\text { High-skilled } \\
(1)\end{array}$ & $\begin{array}{c}\text { Compens. } \\
(2)\end{array}$ & $\begin{array}{c}\text { VA per worker } \\
(3)\end{array}$ & $\begin{array}{c}\text { MPL } \\
(4)\end{array}$ & $\begin{array}{c}\text { MPK } \\
(5)\end{array}$ & $\begin{array}{l}\text { TFP } \\
(6)\end{array}$ & $\begin{array}{c}\text { Public } \\
(7)\end{array}$ \\
\hline MRP & $\begin{array}{c}0.120 \\
(0.046)\end{array}$ & $\begin{array}{c}0.125 \\
(0.163)\end{array}$ & $\begin{array}{c}1.436 \\
(0.608)\end{array}$ & $\begin{array}{c}1.439 \\
(0.745)\end{array}$ & $\begin{array}{c}1.180 \\
(0.556)\end{array}$ & $\begin{array}{c}1.413 \\
(0.557)\end{array}$ & $\begin{array}{l}-0.019 \\
(0.190)\end{array}$ \\
\hline Observations & 12,786 & 77,147 & 77,147 & 77,147 & 77,147 & 77,147 & 77,147 \\
\hline County FEs & Yes & Yes & Yes & Yes & Yes & Yes & Yes \\
\hline Year FEs & Yes & Yes & Yes & Yes & Yes & Yes & Yes \\
\hline Industry FEs & Yes & Yes & Yes & Yes & Yes & Yes & Yes \\
\hline
\end{tabular}

Notes: Robust standard errors are reported between parentheses. All regressions are estimated with Ordinary Least Squares and include industry (2-digit CIC), county and year fixed effects. The main explanatory variable, $M R P$, is a dummy equal to 1 if the firm was originally founded under the " 156 " program, and 0 otherwise. The sample consists of all firms in the treated counties where at least one firm in the NBS annual "above-scale" surveys was identified as descended from one of the " 156 " plants. We further restrict the sample to observations with non-missing data on compensation, value added and factor productivity. High-skilled is the share of college-educated employees in the firm's work force (only available in 2004). Compensation (1996-2008, except for 1997) combines wages, housing subsidies, pension and medical insurance, and welfare payable, divided by total employment. We take the natural logarithm. Value added is available between 1998 and 2007, 2004 excluded. It is expressed in logarithms and normalized by employment. $M P L, M P K$ and $T F P$ are marginal product of labor, marginal product of capital and total factor productivity measures, respectively, estimated using a CES production function with industry-specific elasticity of substitution between capital and labor-see Imbert et al. (2018). Public own. is an indicator variable equal to 1 if the firm is publicly owned, and 0 otherwise. The unit of observation is a firm $\times$ year. 